\title{
WASH INTERVENTIONS IN DISEASE OUTBREAK RESPONSE
}




\begin{abstract}
About this evidence synthesis
This is an independent evidence synthesis commissioned by the Humanitarian Evidence Programme, a partnership between Oxfam GB and the Feinstein International Center at the Friedman School of Nutrition Science and Policy, Tufts University, and funded by the UK government through the Humanitarian Innovation and Evidence Programme at the Department for International Development. The views and opinions expressed herein are those of the authors and do not necessarily represent those of Oxfam, Feinstein or the UK government.
\end{abstract}

The initial database and website searches took place between September 2015 and March 2016. The searches were re-run in September 2016 to check for updated studies.

\title{
About the research team \\ This evidence synthesis was conducted by Travis Yates (Tufts University), Jelena V. Allen (Consultant), Myriam Leandre Joseph (Consultant) and Daniele Lantagne (Tufts University).
}

There were no conflicts of interest in the writing of this report. Authors of this report are also authors of several included evaluations in this review; however, we maintained the systematic review procedure for all documents reviewed.

\section{Citation}

Yates, T., Allen, J., Leandre Joseph, M. and Lantagne, D. (2017). WASH interventions in disease outbreak response. Humanitarian Evidence Programme. Oxford: Oxfam GB.

\section{Acknowledgments}

We would like to thank the Advisory Board members: Andy Bastable, William Carter, Tom Handzel, Melissa Opryszko, Clair Null and Pavani Ram for guidance throughout this project. This work could not have been completed without the help of numerous research assistants at Tufts University who searched websites, screened references and coded evaluations: Shannon Ball, Sean DeLawder, Meagan Erhart, Qais Iqbal, Brittany Mitro, Kyle Monahan, Bhushan Suwal and Marisa Zellmer. We would also like to thank Karin Gallandat for assistance in processing the French evaluations and Karen Vagts, a Tufts University librarian, for helping with the search strategy. Finally, we would like to thank the organizations and individuals who contributed grey literature documents that were critical to this review. Action Contre la Faim and Oxfam, in particular, made significant contributions to advance this review.

\section{Series editors}

The report forms part of a series of humanitarian evidence syntheses and systematic reviews covering child protection, market support, mental health, nutrition, pastoralist livelihoods, shelter, urban contexts and water, sanitation and hygiene.

The reports and corresponding protocols (methodology) can be found at:

- https://www.gov.uk/dfid-research-outputs

- http://fic.tufts.edu/research-item/the-humanitarian-evidence-program/

- http://policy-practice.oxfam.org.uk/our-work/humanitarian/humanitarian-evidenceprogramme

The series editors are: Roxanne Krystalli, Eleanor Ott and Lisa Walmsley.

\section{Photo credit}

As part of Oxfam's cholera response in Juba, South Sudan, teams of public health volunteers have been teaching affected communities about the importance of keeping themselves and their environment clean. May 2014. Kieran Doherty/Oxfam.

\section{(c) Copyright Oxfam GB 2017}

This publication is subject to copyright but the text may be used free of charge for the purposes of advocacy, campaigning, education and research, provided that the source is acknowledged in full. The copyright holder requests that all such use be registered with them for impact assessment purposes. For copying in any other circumstances, or for reuse in other publications, or for translation or adaptation, permission must be secured and a fee may be charged. Email: Iwalmsley1@ght.oxfam.org 


\section{CONTENTS}

0 EXECUTIVE SUMMARY

1 BACKGROUND

1.1 Introduction and objective of review

1.2 Outbreak burden and the role of WASH

1.3 Theory of change

1.4 Importance of review

2 METHODS

$\begin{array}{llr}2.1 & \text { Identification of studies } & 8\end{array}$

$\begin{array}{lr}2.2 & \text { Inclusion criteria }\end{array}$

$\begin{array}{ll}2.3 \text { Synthesis } & 11\end{array}$

2.4 Selection of documents $\quad 12$

$\begin{array}{lll}2.5 & \text { Quality appraisal } & 13\end{array}$

$\begin{array}{lll}2.6 & \text { Contingency analysis and deviations from the protocol } & 14\end{array}$

3 RESULTS 16

$\begin{array}{lll}3.1 & \text { Overview } & 16\end{array}$

$\begin{array}{lll}3.2 & \text { Water: Source-based interventions } & 18\end{array}$

\begin{tabular}{ll}
3.3 & Water: Household water treatment and safe storage \\
\hline
\end{tabular}

$\begin{array}{ll}3.4 & \text { Sanitation } \\ 3.5 & 29\end{array}$

$\begin{array}{lll}3.5 & 3 y g i e n e & 31\end{array}$

$\begin{array}{lll}3.6 & \text { WASH package } & 39\end{array}$

$\begin{array}{lll}3.7 & \text { Beyond the scope of review } & 40\end{array}$

$\begin{array}{lll}3.8 & \text { Economic analysis } & 41\end{array}$

$\begin{array}{lll}3.9 & \text { Summary of interventions } & 41\end{array}$

4 DISCUSSION AND CONCLUSIONS 44

$\begin{array}{lll}4.1 & \text { Review objectives } & 44\end{array}$

$\begin{array}{lll}4.2 & \text { Limitations } & 46\end{array}$

4.3 Recommendations and opportunities for future research 48

$\begin{array}{lll}4.4 & \text { Conclusions } & 49\end{array}$

5 REFERENCES $\quad 50$

$\begin{array}{lll}5.1 & \text { Studies included in evidence synthesis } & 50\end{array}$

$\begin{array}{lll}5.2 & \text { Other studies cited in review } & 52\end{array}$

APPENDIX A - DESCRIPTION OF INCLUDED EVALUATIONS 55

$\begin{array}{ll}\text { Water } & 56\end{array}$

$\begin{array}{lr}\text { Sanitation } & 60\end{array}$

$\begin{array}{ll}\text { Hygiene } & 61\end{array}$

$\begin{array}{ll}\text { WASH package } & 65\end{array}$

APPENDIX B - SEARCHING SUMMARY 68

APPENDIX C - SUMMARY OF EVIDENCE $\quad 71$

APPENDIX D - RISK OF BIAS FOR INDIVIDUAL STUDIES 73

$\begin{array}{ll}\text { Quanitative studies } & 73\end{array}$

$\begin{array}{ll}\text { Qualitative and field commentary studies } & 75\end{array}$ 


\section{ABBREVIATIONS}

ACF

CATS

CHW

CI

CLEME

CLTS

DRC

FCR

FGD

GRADE

$\mathrm{HH}$

HTH

HWT

KII

LMIC

NFI

NGO

OR

PHAST

PICOS

RCT

RR

SWS

SODIS

WASH

WHO

UN

UNHCR

UNICEF
Action Contre La Faim (Action Against Hunger)

Community Approach to Total Sanitation

Community health worker

Confidence interval

Community-Led Ebola Management and Eradication

Community-Led Total Sanitation

Democratic Republic of Congo

Free chlorine residual

Focus group discussion

Grading of Recommendations Assessment, Development and Evaluation

Household

High test hypochlorite

Household water treatment

Key informant interview

Low and middle-income country

Non-food item

Non-governmental organization

Odds ratio

Participatory Hygiene and Sanitation Transformation

Populations, interventions, comparisons, outcomes and study types

Randomized controlled trial

Risk ratio

Safe Water System

Solar disinfection

Water, sanitation and hygiene

World Health Organization

United Nations

United Nations High Commissioner for Refugees

United Nations Children's Fund 


\section{EXECUTIVE SUMMARY}

This evidence synthesis, commissioned by the Humanitarian Evidence Programme and carried out by a team from the Civil and Environmental Engineering Department of Tufts University, identifies, synthesizes and evaluates existing evidence of the impacts of water, sanitation and hygiene (WASH) interventions in disease outbreaks in 51 humanitarian contexts in 19 low and middle-income countries (LMICs). ${ }^{1}$

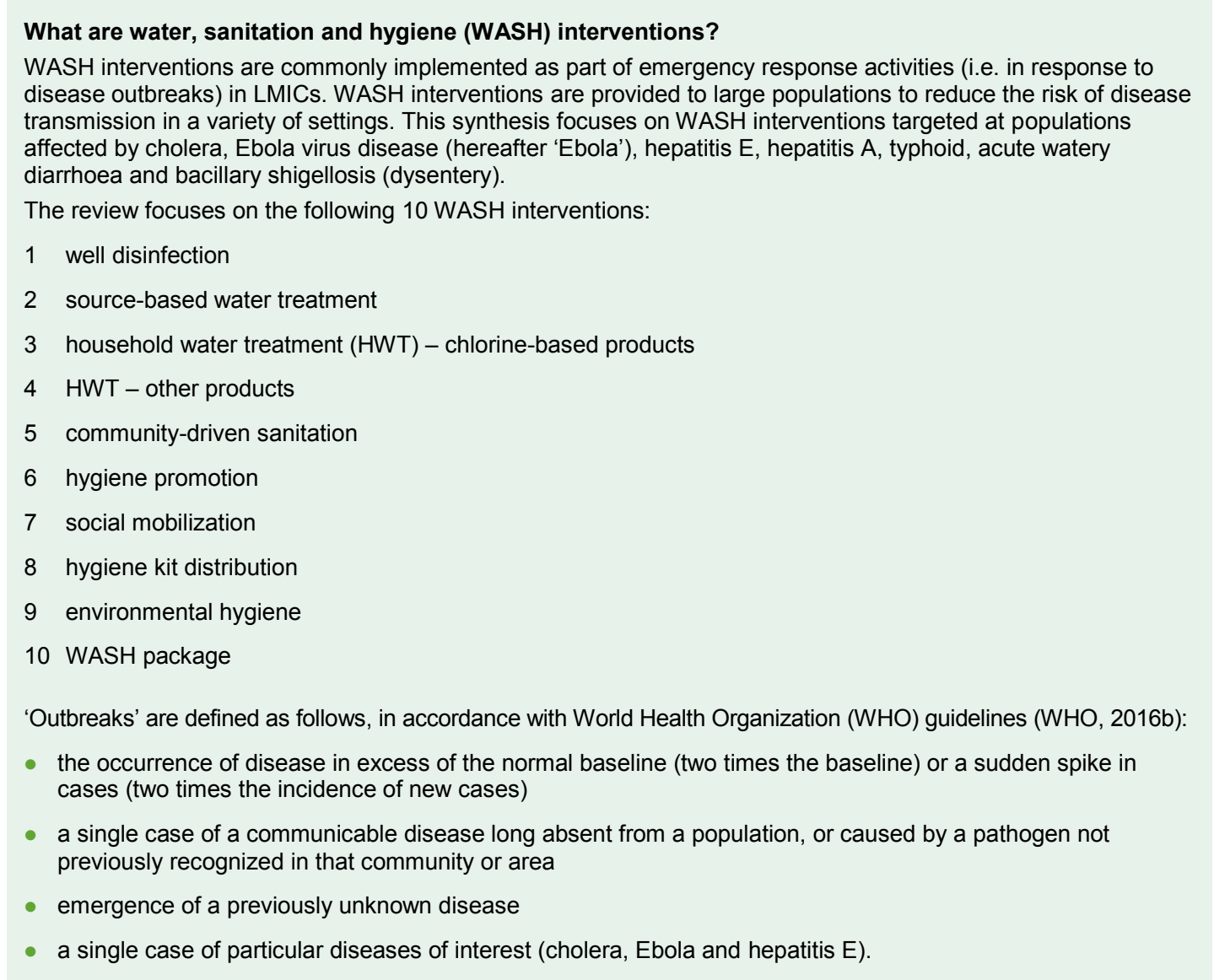

The evidence synthesis aims to:

- verify the quality of existing evidence relating to WASH interventions in humanitarian settings

- help researchers identify the strengths and weaknesses of this evidence, and thus to recognize potential improvements and opportunities for future research

- assist practitioners and policy makers in evaluating the impact of choices and investments.

The research team:

- developed theories of change for the WASH interventions under consideration, documenting the theoretical route from intervention activities to outputs (products distributed, promotion carried out), outcomes (improved WASH conditions and knowledge) and impacts (reduction in disease risk); it also noted influencing risk factors and assumptions between each step (see the review protocol for details: Yates, Vijcic, et al., 2015) $)^{2}$

\footnotetext{
${ }^{1}$ The Humanitarian Evidence Programme is a partnership between Oxfam GB and the Feinstein International Center at the Friedman School of Nutrition Science and Policy, Tufts University. It is funded by the United Kingdom (UK) government's Department for International Development (DFID) through the Humanitarian Innovation and Evidence Programme.

${ }^{2}$ http://policy-practice.oxfam.org.uk/publications/impact-of-wash-interventions-during-disease-outbreaks-in-humanitarian-emergenci605152
} 
What are the health impacts of WASH interventions in disease outbreaks?

- What are important WASH programme design and implementation characteristics in disease outbreaks?

- What are the population-related barriers and facilitators that affect WASH interventions in disease outbreaks?

- What are the economic outcomes of WASH interventions in disease outbreaks?

\section{What evidence was eligible for review?}

Of the 15,026 studies identified in the systematic review process, 47 were deemed suitable following title, abstract and full screening: ${ }^{3}$

- the search criteria included studies published or written between 1995 and 2016 - those included in the review span the period 1998 to $2015^{4}$

- the review covered disease outbreak-affected populations in LMICs

19 countries and 51 contexts are included, with the highest frequency of evaluations from Zimbabwe and Haiti

- only selected diseases of interest were eligible (cholera, Ebola, hepatitis E, hepatitis A, typhoid fever, acute watery diarrhoea and shigellosis)

cholera is the most researched and discussed disease, representing 86 percent $(44 / 51)$ of the diseases in the included evaluations, followed by Ebola $(4 \%, 2)$, acute diarrhoea $(6 \%, 3)$, shigellosis $(2 \%, 1)$ and typhoid fever $(2 \%, 1)$

- eligible interventions include water, sanitation, hygiene and WASH package interventions within 12 months of an outbreak of disease of interest

water interventions are the most evaluated ( $43 \%, 22 / 51$ contexts), followed by hygiene and WASH package, which make up 29 percent (15) and 24 percent (12) of included interventions, respectively; sanitation is least evaluated, making up only 4 percent $(2 / 51)$ of the included studies

- in terms of research design, 49 percent (25) of the studies were quantitative, 18 percent (9) qualitative and 33 percent (17) field commentary.

A roughly equal number of evaluations were identified from the peer-reviewed $(26,51 \%)$ and grey literature $(n=25,49 \%)$. Although the overall number of evaluations is roughly equal between published and grey literature, differences were seen by intervention, with water having more published evaluations and hygiene and WASH package having more grey literature evaluations.

\section{What are the health impacts of WASH interventions in disease outbreaks?}

WASH interventions consistently reduce both the risk of disease and the risk of transmission in outbreak contexts.

- Reduced disease risk: Evaluations of the health impacts of WASH interventions in disease outbreaks using measured change in disease rates were rarely conducted. Only six such evaluations were identified. Five of these involve less common HWT interventions (PUR, simple filters, SODIS and safe storage) and in all cases showed reduced disease rates. The sixth evaluation - a long-running Community-Led Total Sanitation (CLTS) intervention implemented before and during an Ebola outbreak recorded a large and significant reduction in disease risk.

${ }^{3}$ See the review protocol (Yates, Vijcic, et al., 2015).

${ }^{4}$ The initial database and website searches took place between September 2015 and March 2016. 
- Reduced transmission risk: Evaluations of the impact on risk of transmission of WASH interventions were more common than disease risk evaluations and included: well disinfection, chlorine dispensers and HWT (liquid chlorine, chlorine tablets and flocculant/disinfectants). Some evaluations also demonstrated reduced short-term transmission risk with environmental hygiene interventions.

Programme design and beneficiary preferences are important factors in ensuring WASH interventions reach their potential, as described in the following sub-section.

\section{What are important WASH programme design and implementation characteristics in disease outbreaks?}

The following four design and implementation characteristics are identified as important for effective programming.

- Simplicity - Some of the most basic interventions had a clear positive impact; interventions requiring little to no promotion led to incremental improvements that reduced the risk of disease and disease transmission.

- Timing - Prepositioned stock, quick release of funds and early triggers for rapid scale-up were important facets of a positive response, particularly with hygiene kit and HWT interventions.

- Engagement in the community - Community-driven interventions can increase awareness, trigger behaviour change and lead to local solutions.

- Linking relief, rehabilitation and development - Linking with pre-existing programming reduces the need for rapid beneficiary behaviour change, and is an opportunity for responding agencies to increase local cultural understanding for future emergency response programmes.

\section{What are the population-related barriers and facilitators that affect WASH interventions in disease outbreaks?}

Four community perceptions and preferences affecting the success of WASH outbreak interventions are identified.

- Taste and smell: Taste and smell of HWT may hinder use (e.g. chlorine treatments can have an off-putting smell or taste) or facilitate use (e.g. filters and flocculant/disinfectants improve taste)

- Preferred communication: Radio and face-to-face communication were consistently reported as 'most trusted' or 'most valued' for hygiene communication

- Perception of risk: Community understanding of some interventions overestimate effectiveness and risk reduction potential (i.e. household spraying and well disinfection)

- Trust/fear: Social mobilization and open communication between the community and responders builds trust and greater community cohesion.

\section{What are the economic outcomes of WASH interventions in disease outbreaks?}

It was not possible to assess the economic outcomes of WASH interventions as no economic evaluations were found and only minimal cost information is reported.

\section{What's the state of the evidence?}

Overall, the amount and quality of evidence of the health impacts of WASH interventions in outbreaks is found to be lacking and low. As illustrated in the evidence map (see Figure 0.1), the review found better and more quantitative evidence relating to water interventions, 
source-based treatment and HWT than to hygiene, sanitation and WASH package interventions, which tend to be assessed with lower quality and in more qualitative studies.

While the 47 studies analysed provided solid information to generate comments, there were some limitations of the evidence, including:

- none include high quality evidence relating specifically to health impacts

- while they show consistent findings, most are low quality cross-sectional study designs, only two randomized controlled trials are included in the review

- those that are quantitative studies (mainly published and relating to water interventions) have less risk of bias

- those that evaluate WASH package interventions tend to be field commentary, unpublished and with a high risk of bias

- none provide evidence of the impacts of well rehabilitation, bucket chlorination, latrine building, handwashing, household spraying, water trucking, environmental drainage/clean-up or cost-effectiveness of any intervention

- none provide formal economic analysis of WASH interventions in disease outbreaks.

This weak evidence base is attributed to two factors:

1 the prioritization of rapid response activities over research in emergency contexts

2 the difficulty of conducting research in the rapidly changing and unstable settings where disease outbreaks often occur.

Figure 0.1: WASH interventions in disease outbreaks - evidence map. Source: The research team

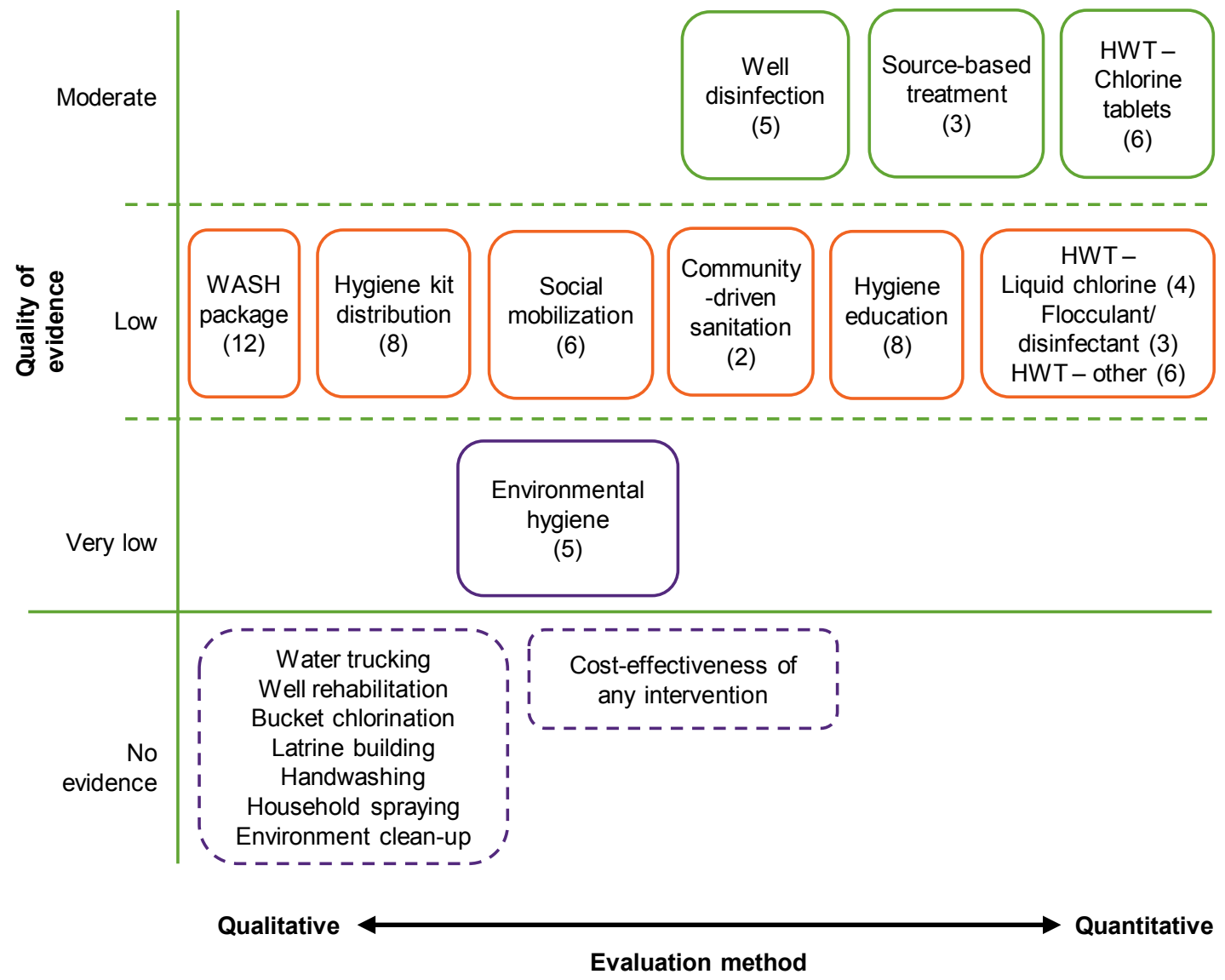




\section{Additional insights and observations}

While WASH interventions in disease outbreaks are under-researched, it is likely that population-related barriers and facilitators will remain critical to the success of WASH interventions and remain context specific. As such, for the sake of more effective interventions in the future, the following activities should be considered:

- well-designed non-experimental and qualitative studies to increase the evidence base, particularly on well rehabilitation, bucket chlorination, latrine building, household spraying, handwashing, water trucking, environmental drainage/clean-up and cost-effectiveness

- developing templates and protocols for consistent and robust evaluations

- evaluating interventions at the beneficiary level

- identifying intervention factors that lead to more scalable and more timely responses

- increasing responders' understanding of community preferences and cultural differences.

Overall, we found low quality but consistent evidence that some WASH interventions are successful at reducing the risk of disease transmission, although programme design, implementation characteristics and community aspects are critical to programme success. 


\section{INTRODUCTION AND OBJECTIVE OF REVIEW}

Water, sanitation and hygiene interventions (WASH) are commonly implemented as part of emergency response activities (i.e. in response to disease outbreaks) in low and middleincome countries (LMICs). However, there is a lack of evidence on the efficacy and effectiveness of these interventions (Blanchet et al., 2013; Ramesh et al., 2015). This weak evidence base is attributed to two factors: 1 ) the prioritization of conducting rapid response activities (over research) in emergency contexts; and 2) the difficulty of conducting research in the rapidly changing and unstable settings where disease outbreaks often occur.

The objective of this report is to assess the outcomes and impacts of WASH interventions during disease outbreaks in LMICs. We aim to address four knowledge gaps in WASH interventions during outbreak response:

1 How does the use of WASH interventions reduce disease outbreaks?

2 What are the programme design and implementation characteristics that are associated with more effective programmes?

3 What is the cost effectiveness of WASH interventions in emergency outbreak situations?

4 What are the barriers and facilitators to WASH interventions in outbreaks?

In the following sub-sections, the role of WASH interventions in outbreak response (Section 1.2), the theories of change for WASH interventions in outbreak response (Section 1.3) and the importance of the review (Section 1.4) are described.

\subsection{OUTBREAK BURDEN AND THE ROLE OF WASH}

An outbreak occurs when the number of disease cases increases above what would normally be expected in a defined community, geographical area or season (GIDEON, 2016). Between 1980 and 2013, 12,102 outbreaks of 215 human infectious diseases, including more than 44 million cases, were reported into the Global Infectious Disease and Epidemiology Online Network (GIDEON) from 219 nations (Smith et al., 2014). Furthermore, both the number and diversity of disease outbreaks have increased significantly from 1980 to 2013 , although cases per capita have decreased. These increases are attributed to microbial adaption of pathogens; changing human susceptibility; climate change; changing human demographics; economic development; breakdowns in public health; poverty and social inequality; and war and famine. 
Figure 1.1: F-Diagram. Source: Water 1st International 2015

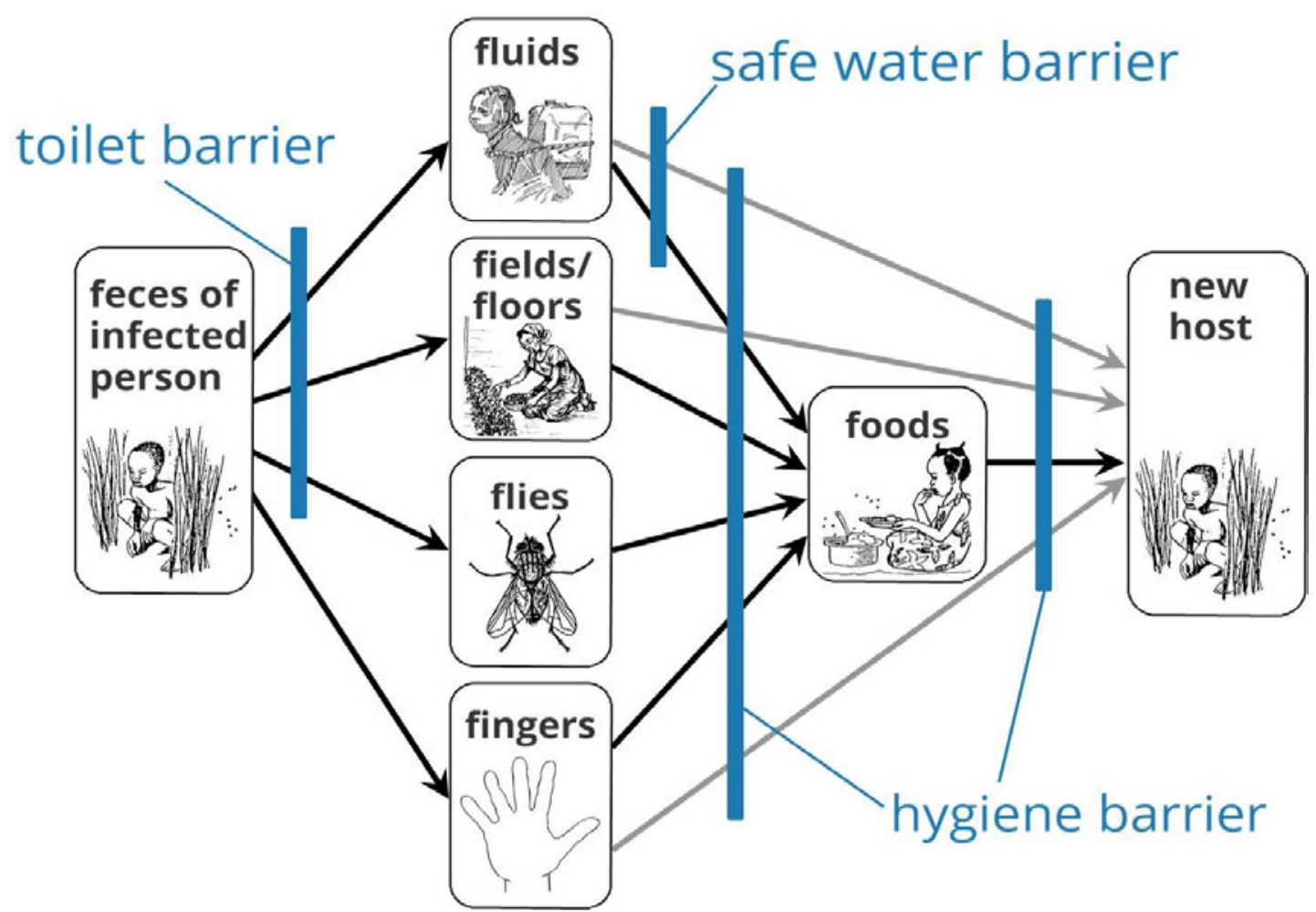

Many of these outbreaks are preventable (Sphere Project, 2011), and WASH interventions are one key component to reducing the burden of disease associated with some outbreaks. WASH interventions can prevent and control waterborne diseases, diseases transmitted through the faecal-oral route and diseases transmitted by direct contact (Sphere Project, 2011, 2014; Watson et al., 2007). This F-Diagram depicts how WASH interventions can interrupt disease transmission routes (Figure 1.1).

There are three diseases of particular and current interest in outbreak response in LMICs: cholera, Ebola virus disease (hereafter 'Ebola') and hepatitis E.

Cholera is caused by ingestion of the bacterium Vibrio cholerae in contaminated water and food, and is a severe acute diarrheal disease that can cause death from dehydration within hours if untreated; with treatment a case fatality rate of $<1$ percent is expected (WHO 2016a). More than 90,000 deaths and 2.8 million cases are caused by cholera each year (Ali et al., 2012). Cases are currently increasing internationally (Gaffga et al., 2007), with a 47 percent increase between 2013 and 2014 alone (WHO 2016d).

Ebola is a viral haemorrhagic fever caused primarily by direct contact with an infected individual in late-stage disease or after death during unsafe burials; indirect contact with fomites (objects) or a bodily fluid-contaminated surface can also cause transmission. Case fatality rates in Ebola range from 50 to 90 percent (Legrand et al., 2007). The Ebola outbreak in West Africa in 2014-2015 was unprecedented in scale, with 28,626 cases and 11,323 deaths, and impacted the entire global community as it was declared a 'public health emergency of international concern' by WHO (WHO, 2016c).

Hepatitis $E$ is a viral liver disease transmitted primarily via the faecal-oral route by contaminated water and is usually self-limiting in humans (Aggarwal and Naik, 2009). However, is some cases, particularly in pregnant women, hepatitis $\mathrm{E}$ can cause acute liver failure, and recently hepatitis $E$ outbreaks have become more common in displacement camps (Boccia et al., 2006; Hakim et al., 2016).

All three of these diseases can be prevented and controlled with WASH interventions (Figure 1.2). 
Figure 1.2: Diseases transmission and WASH mitigation for diseases of concern

\begin{tabular}{|l|l|l|}
\hline Disease of interest & Transmission & Possible WASH management \\
\hline Cholera & Faecal-oral & Safe water, sanitation and hygiene \\
\hline Hepatitis E & Faecal-oral & Safe water, sanitation and hygiene \\
\hline Ebola & Direct contact with bodily fluids & $\begin{array}{l}\text { Precautionary personal hygiene } \\
\text { measures, local (household or clinic), } \\
\text { environmental control }\end{array}$ \\
\hline
\end{tabular}

While responders identified the diseases in Figure 1.2 as primary diseases of interest for the review, the other waterborne diseases of hepatitis A, acute (watery) diarrhoea, typhoid and dysentery were also within the scope of this review.

\section{WASH intervention description}

WASH interventions in outbreak situations are not necessarily intended to provide long-term sustainable access, but instead provide rapid relief to minimize the impact or spread of disease (Sphere Project, 2011). The main components of WASH interventions are:

Water - Water interventions in outbreak response aim to increase water quantity or water quality. Increasing water quantity is a necessary step in providing potable water, and also enables hygiene and sanitation practices. Use of water quality interventions at the source or in the household can reduce microbial contamination of drinking water.

Sanitation - Sanitation interventions in outbreak response aim to isolate faeces from the environment. Minimizing open defecation and ensuring proper management of faeces in a latrine or latrine alternative reduces exposure to infectious waste and can reduce disease transmission.

Hygiene - Hygiene messages promote awareness among affected or at-risk populations on the disease and transmission routes, while distribution of hygiene kits equip populations to act on hygiene messages. Environmental hygiene interventions reduce risks by disinfecting household objects and managing rubbish.

As the broad categories of water, sanitation and hygiene are not sufficiently specific for analysis, eight detailed WASH interventions commonly implemented in outbreaks were defined for the review, including three in water, two in sanitation and three in hygiene. The specific WASH interventions identified in the protocol are:

1 increasing access to water

2 source-based water treatment

3 household water treatment (HWT)

4 temporary or permanent latrines

5 latrine alternatives

6 hygiene promotion, including handwashing

7 distribution of soap and/or hygiene materials/kits

8 environmental hygiene.

Please note these eight interventions were modified to a group of 10 interventions after reviewing the included documents. Additional detail and description on each of the specific 10 interventions is provided in Section 3, Results. 


\section{Actors in outbreak response}

Effectively responding to an outbreak requires collaboration between different actors.

- United Nations (UN) agencies lead emergency 'clusters' covering the range of humanitarian needs in an emergency (e.g. WASH, health, shelter). Different UN agencies lead specific areas of expertise within the overall response, requiring coordination between actors.

- WHO typically leads the UN response in disease outbreak settings by helping to manage and coordinate other UN agencies, local government and non-governmental organizations (NGOs). WHO also leads the Health Cluster, which is responsible for coordination of hospitals, clinics and temporary treatment units. United Nations Children's Fund (UNICEF) typically leads and coordinates the WASH Cluster in disease outbreaks.

- The Global Outbreak Alert and Response Network (GOARN) and Centers for Disease Control and Prevention also house expertise and resources dedicated to rapid response to outbreaks.

- Local governments are involved in many on-the-ground aspects of outbreak response, from agency coordination to treatment centres and municipal services.

- NGOs play a key role in working directly with the communities and in coordination. Additionally, some NGOs specialize in emergency response in outbreaks and manage treatment centres (i.e. Action Contre la Faim (ACF), Médecins sans Frontières and International Medical Corps).

Collectively, these collaborators are referred to as 'responders' throughout this review.

\subsection{THEORY OF CHANGE}

The goal of all WASH interventions in outbreaks is to reduce the risk of disease transmission. For this review, a theory of change model has been developed for each of the eight initial WASH interventions described in the previous section that: 1) documents the theoretical route from intervention activities to outputs, outcomes and impacts (disease reduction); and 2) includes influencing factors and assumptions (Yates, Vujcic, et al., 2015). The theory of change template is presented in Figure 1.3, and the eight initial specific models are included in the protocol in Yates, Vijcic, et al. (2015).

The extent to which WASH interventions are successful in interrupting transmission depends on their efficacy and effectiveness. Efficacy is the theoretical potential for breaking transmission routes, and answers the question 'Could the intervention work?' Effectiveness includes contextual factors of the intervention such as implementation quality, the natural environment, culture and social preferences, and answers the questions 'Was the intervention implemented correctly?' and 'Did the intervention have the outcomes and impacts that are possible and were intended in the target population?' 
Figure 1.3: Theory of change template for WASH interventions. Source: The research team, adapted from WHO (2014)

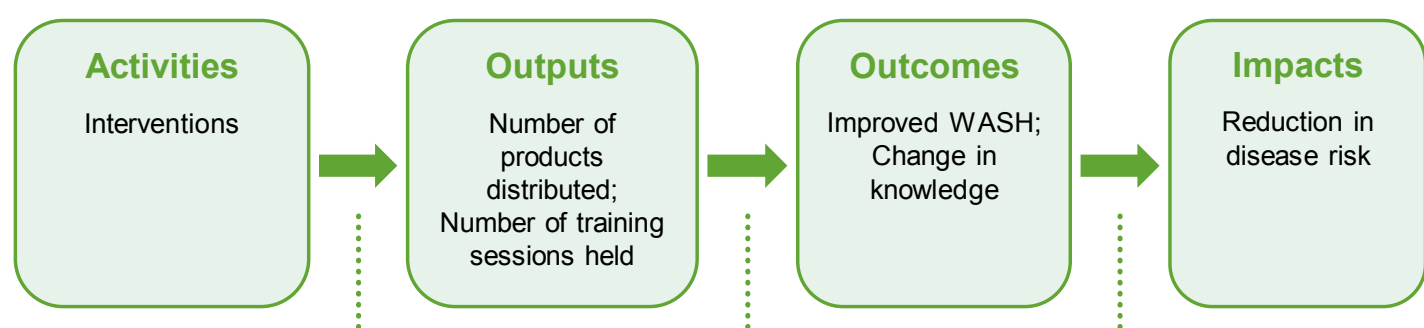

Influencing factors and assumptions

(e.g. type of disease outbreak; type of co-emergency; baseline health; local knowledge; environmental conditions; season/climate; economic conditions; user preferences; market availability; existing community and household WASH practices)

To illustrate the difference between efficacy and effectiveness, the theory of change for a combined HWT intervention and hygiene education intervention is depicted in Figure 1.4. In this example, a water filter and hygiene education are distributed to households; both are known to be efficacious from previous laboratory and field studies. The assumptions detailed at each stage of the model show the steps necessary to achieve correct and consistent use in the target population, that is, effectiveness.

Figure 1.4: Theory of change: HWT and hygiene education example. Source: The research team

Assumptions
Logistically (procurement and
distribution) and financially
feasible
- Water sources previously exist

\section{Assumptions}

- Amount of water is sufficient for population

- Distance to source is appropriate

- All populations have access to water

- Supplies are consistent and maintained

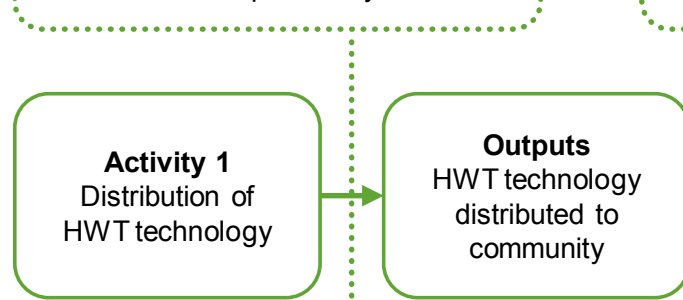

.................................................
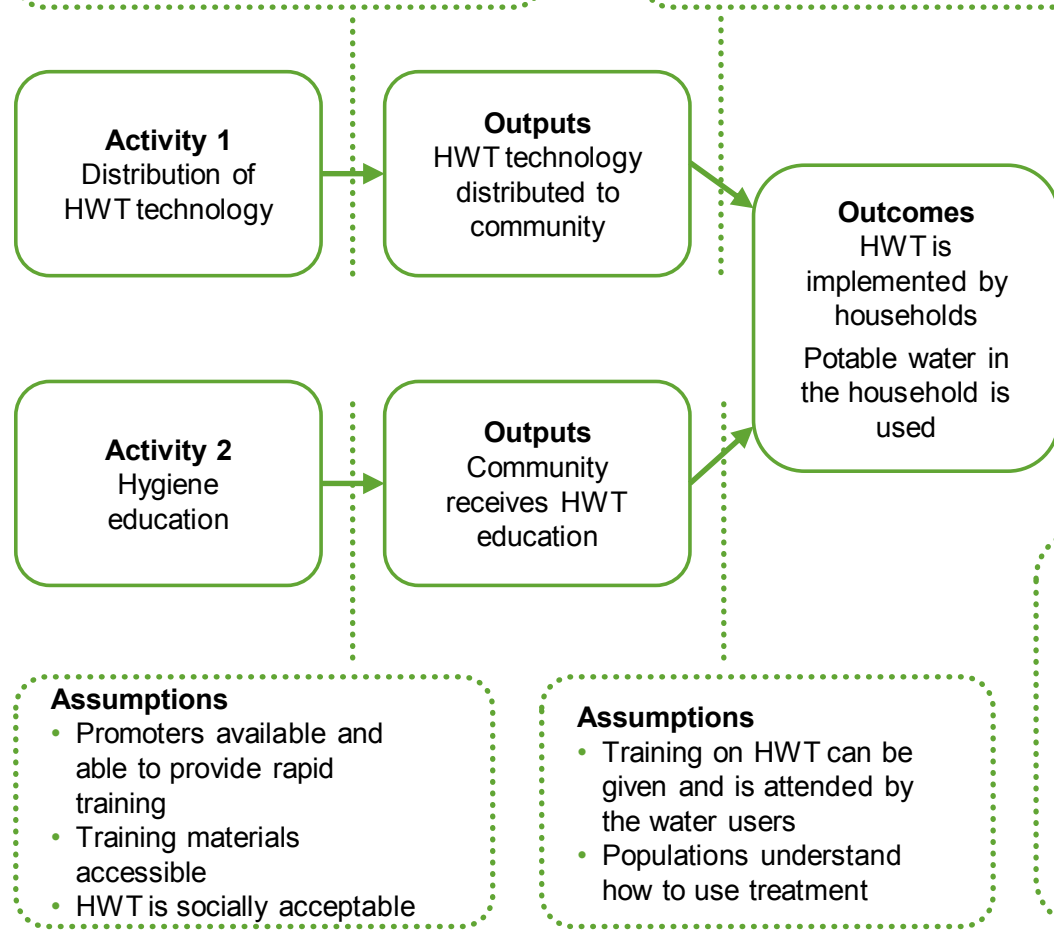
Assumptions
- Training on HWT can be given and is attended by the water users
- Populations understand how to use treatment

Impact

Reduction in disease morbidity

As a part of a larger WASH review, a systematic review of cholera case-control studies was conducted, and is described in Box 'Cholera case-control study review example' on p. 6 . The risk and protective factors identified in the case-control studies quantified the influence of assumptions in the causal chain and validated our theory of change models. 
Cholera case-control study review example

A systematic review of cholera case-control studies identified 77 studies and nine exposure pathways represented by the F-Diagram (Figure 1.1), socioeconomic status and local customs (i.e. actions at a funeral) (Kaur 2016). Each exposure pathway consisted of a protective factor and the opposing risk factor. For instance, access to treated water was protective, and the lack of treated water was a risk. In total, 12 protective factors and 23 risk factors were identified in the nine exposure pathways. The most notable conclusions were that 50 percent $(6 / 12)$ of the protective factors significantly reduced the odds of contracting cholera $(p<0.05)$, yet all 23 risk factors significantly increased the odds of contracting cholera $(p<0.05)$. This indicates that, for example, the absence of treated water or a latrine increases the risk of disease; however, the opposite, access to treated water or a latrine, is not always protective in preventing cholera. The WASH intervention theory of change was validated by noting that the influencing factors and assumptions play an important role in the impact of a WASH intervention. Improved WASH access or increased knowledge does not always translate to a reduction of disease, thus an appreciation of local customs, ease of use and other factors must be considered to achieve impact.

This review is important and timely for three reasons (which are then described in detail):

1 previously published reviews have not had sufficiently broad inclusion criteria or developed policy relevant recommendations

2 in the absence of evidence, decision making in outbreaks is sometimes inappropriate

3 disease outbreaks are currently increasing due to climate change and population growth.

Two 2015 reviews on WASH interventions conclude there is a lack of evidence to support implementing WASH interventions in outbreaks and emergencies (Taylor et al., 2015; Ramesh et al., 2015). The reviews found that the quality of evidence is low and limited to only a small portion of interventions, primarily focused on HWT. However, neither review had inclusion criteria that enabled a full appreciation for the scope of information in outbreak response, ultimately leading to few included studies and a narrow scope of interventions. Taylor et al. focused only on cholera and did not include grey 'unpublished' literature and Ramesh et al. only investigated health impacts for WASH interventions in emergencies. The work presented here includes both published and grey literature, broader inclusion criteria and additional outcomes compared with these 2015 reviews. Previous manuscripts have highlighted the need to inform global policy by identifying which WASH interventions are evidence-based and which need further research (Parkinson, 2009; Darcy et al., 2013). Ideally, the evidence base would draw from published literature, as well as grey literature and qualitative information through a clearly defined review (Brown et al., 2012). This review addresses these previously identified needs.

In the absence of evidence, WASH interventions currently used in outbreak response are often ones shown to be efficacious and effective in development contexts, rather than emergencies (Darcy et al., 2013; Parkinson, 2009). Additionally, responders often default to familiar interventions using 'intuition' and 'if it worked before it will work again' mentalities (Darcy et al., 2013; Loo et al., 2012; Steele and Clarke, 2008). As the effectiveness of WASH interventions depends on contextual factors unique to each disease outbreak emergency (Bastable and Russell, 2013; Loo et al., 2012; Parkinson, 2009), these unjustified assumptions have led to use of interventions in inappropriate situations (Dorea, 2012; Loo et al., 2012). Contextually appropriate information on WASH intervention effectiveness may provide more relevant and effective guidance for responders and lead to better WASH interventions in disease outbreaks. For example, in northern Uganda there are cultural beliefs that a disease outbreak was caused by 'bad spirits', not water, and responders need to understand the local beliefs and the potential impact on use of WASH interventions while responding (de Vries et al., 2016).

Lastly, the number and diversity of outbreaks is increasing (Smith et al., 2014), and outbreaks are anticipated to continue to increase as the factors contributing to outbreaks, such as climate change and increases in population density, intensify. A better understanding of the efficacy and effectiveness of WASH interventions in outbreaks can shape how WASH interventions are implemented to better reach and serve the target communities (Cairncross et al., 2013). 


\section{How to read this review}

This review is intended to provide policy makers and responders with a comprehensive understanding of the available information on the effectiveness of WASH interventions in outbreak response. It is a systematic synthesis of relevant information intended for a reader with a basic understanding of WASH interventions. The reader is referred to the WASH Gap Analysis (Bastable and Russell, 2013), the Humanitarian Innovation Fund Problem Explanation Reports (Ali and Kadir, 2016; Ramos et al., 2016; Reed and Mena-Moreno, 2016; Tota-Maharaj, 2016; Grange, 2016) and NGO technical guidance documents for information outside the scope of this review. 
A protocol was developed to identify published and grey literature documents with quantitative and qualitative outcomes from a wide network of sources. The full protocol is available on the Oxfam Policy and Practice website. ${ }^{5}$ Here, a brief summary of the methods for identification of studies, inclusion criteria, selection process and quality appraisal are presented.

\section{$2.1 \quad$ IDENTIFICATION OF STUDIES}

\section{Database and website searching}

A comprehensive and systematic search strategy was developed to identify published and grey literature. All search strings for the WASH interventions included terms related to emergencies, disasters and outbreaks as well as LMICs. Individualized search terms were developed for each of the eight initial WASH interventions from their associated theory of change, and included keywords and outcome and impact measures specific to that intervention (Yates, Vijcic, et al., 2015). The eight search strings were used in a total of nine peer-reviewed databases, in English (7), French (2) and English/Spanish (1) including: Cochrane Library, Google Scholar, IDEAS, LILACs, Ovid Medline (PubMed), Scopus, Web of Science, Academic Search Premier (English and French) and ArticleFirst. An example search string for HWT is shown in Box, 'Search string example - household water treatment' below.

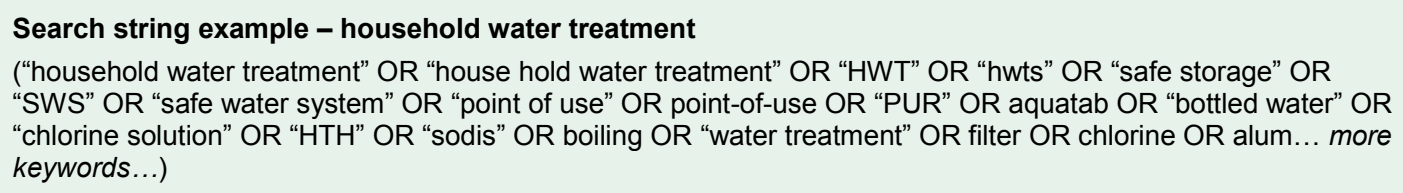

("LMIC" OR "low and middle income" OR "low-and-middle-income" OR Afghanistan OR Libya OR Albania OR Macedonia OR Algeria OR Madagascar OR "American Samoa" OR Malawi OR Angola OR Malaysia OR Armenia OR Maldives OR Azerbaijan OR Mali OR Bangladesh OR ... more countries...)

* indicates a word that has been truncated in order to search for variations of the word.

The journals most likely to have relevant research were also searched by hand. NGO, UN and other relevant emergency responder websites were searched with simplified keyword strings, as many sites were not equipped for complex word searches or did not have data repositories. For example, an NGO website without a data repository might be examined through the search bar with keywords like: 'water emergency' or 'disease outbreak.' The references list of all relevant review documents found in the search and all included evaluations was also reviewed to identify additional documents.

\section{Open requests for information}

Email requests for reports, data and general information (included in the term 'studies' hereafter) on WASH interventions in outbreaks were sent out to the Global WASH Cluster email list in September 2015 and February 2016 and to the Working Group of the International Network on Household Water Treatment and Safe Storage and personal contacts lists in September 2015. More than 75 organizations were contacted through email. Additionally, Evidence Aid posted requests for information on its Facebook page and sent

\footnotetext{
${ }^{5}$ http://policy-practice.oxfam.org.uk/publications/impact-of-wash-interventions-during-disease-outbreaks-in-humanitarian-emergenci-605152
} 
email messages to specific people. Organizations and individuals were also approached at the Emergency Environmental Health Forum in Nairobi in October 2015 (where an oral presentation on this work was presented) and the University of North Carolina Water and Health Conference: Where Science Meets Policy in October 2015 (where a poster on this work was presented).

Additional searching and solicitation is described in Appendix B.

\section{$2.2 \quad$ INCLUSION CRITERIA}

Inclusion criteria were established in the protocol to define: populations, interventions, comparisons, outcomes and study types (PICOS) (Yates, Vujcic, et al., 2015). The definitions were developed to guarantee transparency in selection of included evaluations and were approved through a peer review process. General inclusion criteria are summarized in this section, with detailed criteria available in the protocol.

Populations - All age, gender and socioeconomic populations were eligible for inclusion, provided they lived in LMICs. Populations must also have been affected by cholera, Ebola, hepatitis $\mathrm{E}$, hepatitis $\mathrm{A}$, typhoid fever, acute watery diarrhoea, or bacillary dysentery (shigellosis). These diseases were selected because they are of particular and current interest in outbreak response as detailed in Section 1, or are common diseases where WASH interventions can break known transmission routes. For this analysis, we define an outbreak in accordance with WHO (WHO, 2016b) as:

- the occurrence of disease in excess of the normal baseline (two times the baseline) or a sudden spike in cases (two times the incidence of new cases)

- a single case of a communicable disease long absent from a population, or caused by a pathogen not previously recognized in that community or area

- emergence of a previously unknown disease

- a single case of particular diseases of interest (cholera, Ebola and hepatitis E).

While WASH interventions could assist in prevention or control of other transmission routes, these routes were not eligible for review, including vector-borne (e.g. malaria, Dengue fever); airborne (e.g. influenza A virus subtype H1N1); foodborne (e.g. food-related salmonella); and blood/sexually transmitted (e.g. hepatitis C, HIV) diseases.

Interventions: A WASH intervention was eligible for review if it targeted prevention or control of one or more included diseases and was carried out within 12 months of the start of the outbreak. Researchers identified eight initial interventions known to be part of outbreak responses: 1) increasing access to water; 2) source-based water treatment; 3) HWT; 4) temporary or permanent latrines; 5) latrine alternatives; 6) hygiene promotion, including handwashing; 7) distribution of soap and/or hygiene materials/kits; and 8) environmental hygiene. Please note municipal water supply is generally not considered an outbreak response activity and as such is not included in the review.

Comparisons: No specific comparisons were required for inclusion.

Outcomes: Evaluations were included if at least one intermediate outcome (use of service or economic analysis) or final impact (disease reduction or non-health outcomes) was reported.

- Use of service - Use of service is a general term that includes three specific indicators: self-reported use, confirmed use and effective use. Self-reported use is when a beneficiary reports the use of a product or event without additional verification; this indicator is often heavily biased. Confirmed use is when the evaluation tests, observes or confirms a product or service was used in some way (i.e. testing free chlorine residual (FCR) in household drinking water confirms the use of a chlorine water treatment method). Effective use is the percentage of households improving their environmental hygiene quality from contaminated to uncontaminated by using a particular intervention. Effective use is a measure of risk reduction that is often assessed via microbiological testing. 
- Economic analysis - Economic analyses types included are: cost-benefit analysis, costutility analysis, cost per beneficiary, cost of products and cost per disability adjusted lifeyear averted.

- Disease reduction - Health impact data is included if beneficiary morbidity and mortality impact are expressed as an odds ratio (OR), risk ratio (RR), disease prevalence or incidence rate. Odds or risk ratios less than 1 show the intervention is protective; ratios greater than 1 reflect an increase in risk from the intervention. The intervention statistically significantly increases or decreases risk if the confidence interval around the point estimate does not include 1.

- Barriers and facilitators - Non-health related factors of preferences from the population on use of interventions (e.g. ease of use, taste or smell of water), quality of life improvement (e.g. feeling safer, time savings) and agency preferences for interventions are included.

Study types: Experimental, quasi-experimental, non-experimental, mixed-methods and qualitative methodological designs were eligible for review.

Document types: Both peer-reviewed and grey literature documents were eligible for review. Grey literature can include: quantitative or qualitative research and/or field commentary documents. However, personal blogs, diaries, newspapers articles, magazine articles, website postings, poster abstracts and legal proceedings/court documents are not included; these are collectively termed 'policy documents and other information'. Systematic review documents are not included, but individual references were screened for inclusion.

As the scope of this review is wide, for ease in comparing and presenting data, all included documents are categorized as quantitative, qualitative and/or field commentary (2.1). For the purpose of this review, quantitative documents include quantitative and mixed-method evaluations, typically including household surveys. Qualitative documents rely exclusively on beneficiary focus group discussions and key informant interviews. Field commentary documents are organizational or personal reflection on a particular intervention and sometimes also include focus groups or key informant interviews from NGO, UN or government staff (non-beneficiary).

Figure 2.1: Study classification. Source: The research team

Study type

Quantitative Household surveys and other quantitative methods

Included

Qualitative Beneficiary focus group discussions and key informant interviews

Field commentary Organizational reflections, focus groups and key informants

Not included

Policy documents

Other information
Global description or opinion of interventions Cross-cutting themes and information not meeting the inclusion criteria but may be referenced in the document 
$2.3 \quad$ SYNTHESIS

Due to the included study designs, narrative synthesis is used to summarize the information in the review. Quantitative studies evaluate health, use and economic outcomes, as well as barriers and facilitators. Programmatic factors and beneficiary preferences are coded and summarized by theme for all study types (Figure 2.2). Comparison tables and figures are used to show differences and similarities within interventions. The quality of evidence for each outcome of an intervention follows the quality of evidence described in Section 2.4 and the protocol (Yates, Vijcic, et al., 2015).

\section{Figure 2.2: Source of data retrieval flow diagram. Source: The research team}

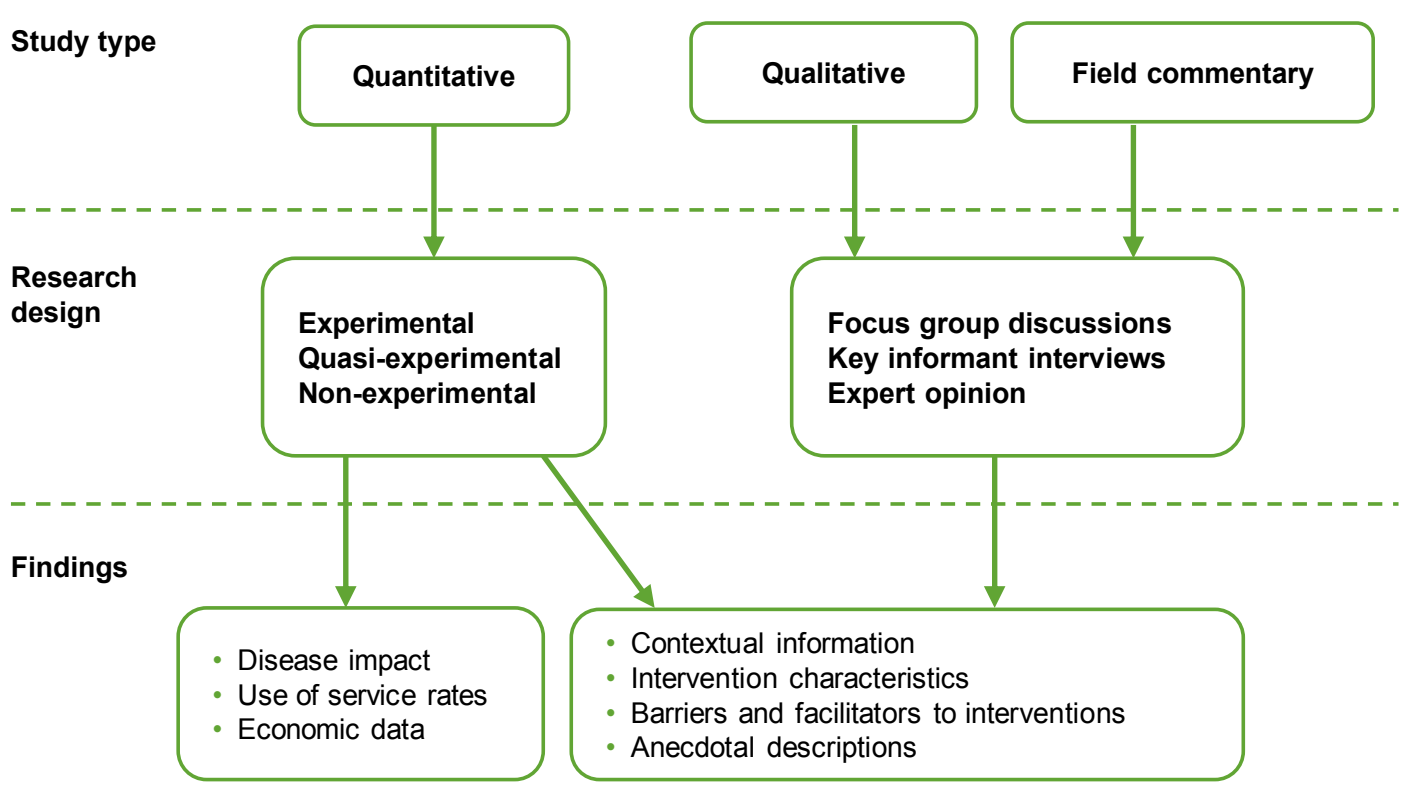

The search strategy was tailored for eight different emergency WASH interventions; however, on review of the included studies, more specific intervention categories were found to be necessary to improve intervention comparisons. Ultimately, 10 intervention categories were determined by the research team to better describe the interventions; these are subsets of the original categories, including: four in water, one in sanitation, four in hygiene, and an additional category for WASH package interventions including aspects of water, sanitation and hygiene carried out in unison without a clear emphasis on any one intervention type (Figure 2.3).

Please note: these are primary intervention categories and may include several more specific interventions; for instance, HWT - chlorine-based products includes: chlorine tablets, liquid chlorine and combination flocculant/disinfectants. 
Figure 2.3: Intervention categories. Source: The research team

Original interventions (8)

1) Increasing water access

2) Source-based treatment

3) Household water treatment
Revised interventions (10)

1) Well disinfection

2) Source-based treatment

3) HWT - chlorine-based products

4) HWT - other products

SANITATION $\quad$ 4) Latrines $\quad$ 5) Community-driven sanitation

5) Latrine alternatives

HYGIENE

6) Hygiene promotion

6) Hygiene education

7) Social mobilization

7) Soap/hygiene kits

8) Hygiene kit distribution

8) Environmental hygiene

9) Environmental hygiene

10) WASH package

\section{$2.4 \quad$ SELECTION OF DOCUMENTS}

All identified documents were screened according to the standards of Cochrane Intervention Reviews (Higgins et al., 2013) by title, abstract and full text review.

Title screening - A single researcher removed documents that were not: WASH related, from LMICs, published between 1995 and 2016 or field-based interventions. Any document that was questionable was included for review in abstract screening.

Abstract screening - Included documents from the title screening were independently assessed by two researchers based on the abstract or executive summary. In addition to the first filter criteria, long-term projects of more than 12 months and interventions in development or protracted contexts were eliminated. If a document was approved by either researcher, the document was included for full text screening.

Full text screening - Included documents from the abstract screening were independently assessed by two researchers to determine if they adhered to all the previous criteria and included at least one of the four intermediate outcomes or final impacts. The researchers needed to agree for the study to be included in the review. Any discrepancies were discussed by a third member of the research team for a final decision.

Throughout the screening process, references were managed with Endnote X7 (New York, NY, USA) and Microsoft Excel 2010 (Redmond, WA, USA). 


\section{Data collection and management}

For included studies, data collection was done with a detailed coding sheet using Microsoft Excel 2010. Data collection included: author and publication details, type of intervention, context of the intervention, study design, study quality, effect estimation, outcomes, and barriers and facilitators to implementation. Data collection was completed by four research assistants and double screened to ensure accuracy.

\subsection{QUALITY APPRAISAL}

The quality appraisal included two parts: an assessment on the quality of each included study, and an assessment of the total quality of evidence for each WASH intervention.

\section{Individual study assessment}

Each included study was assessed for the potential risk of bias, with different tools used for quantitative and qualitative/field commentary evaluations. The risk of bias of a study is an important step that assesses the validity of the reported findings and conclusions. The full description of terms and processes are in the protocol and briefly summarized here.

Quantitative evaluations - To assess the risk of bias in quantitative studies, an assessment tool was developed based on the Cochrane Handbook 'Risk of bias' tool and formatted similarly to Baird et al., (2013) (Higgins and Green, 2008; Baird et al., 2013). The risk of bias was assessed through five categories.

- Selection and confounding - Addresses the bias within evaluation methodology design, selection of beneficiaries and matching concerns.

- Spillover effects and contamination - Addresses the issue of spillovers from the treatment to the control group. Not controlling for outside factors or for additional interventions in the area also has spillover effects.

- Incomplete outcome - Addresses the issue of whether analysis of all relevant outcomes was reported or whether there appears to be selective reporting. Loss to follow up or missing data can reduce the power of the research design as well as potentially introduce bias with unequal loss of sample between groups.

- Selective reporting - Authors use a credible analysis method and report on all intended outcomes. Some research is funded by manufacturers of products, which can lead to selective reporting of only favourable outcomes.

- Other risks of bias - This category is for any number of other risks of bias present in the report. Self-reported data is of particular concern for our analysis. Also, retrospective baseline data, data using inappropriate methods, and changing follow-up methods or procedures are examples of other potential biases. This is the most subjective of the five categories.

Each study was scored across the five categories as 'low risk,' 'medium risk', 'high risk' or 'unclear.' The summary risk of bias for an individual study is based on the number of 'low risk' assessments across the five categories. If there are four or more low risk assessments the study is considered low risk, if there are three it is medium risk and if there are two or fewer it is high risk.

Qualitative/field commentary evaluations: The qualitative assessment was adapted from Spencer et al. (2003) Quality in Qualitative Evaluation: A framework for assessing research evidence (Spencer et al., 2003). The quality assessment is evaluated on four appraisal categories:

- Design - The overall design of the research is considered, especially the targeting of the research population. 
- Bias - How representative is the research population and are there obvious biases that affect the findings?

- Data collection - How was the data collected, recorded (audio, video, transcribed)? Who collected the information?

- Clarity of findings - Do the conclusions match what could be achieved from the study design? Is there an inherent logic to the conclusions?

Each study was scored across the four categories as 'low risk,' 'medium risk', 'high risk' or 'unclear.' The summary risk of bias for a qualitative/field commentary study is based on the number of 'low risk' assessments across the four categories. If there are three or more low risk assessments, the study is considered low risk, if there are two it is medium risk and if there is one or zero it is high risk.

\section{Quality of evidence for each intervention}

To establish the summary of evidence from multiple studies of varying qualities and study designs, a protocol was developed to establish transparency in communicating the overall evidence for outcomes and interventions. The summary of evidence protocol is based on a Grading of Recommendations Assessment, Development and Evaluation (GRADE) of evidence outlined in Cochrane Review; however, some modifications were made so there would be less emphasis on randomized controlled trials (RCT), which are known to be rarely carried out in humanitarian research. A three-step evaluation process was used to determine the level of evidence with transparency. The baseline of evidence (Step 1) is determined by the study design. Then, steps 2 and 3 downgrade or upgrade the baseline evidence considering biases, effect size, consistency and generalizability (Figure 1.2; see Appendix C for further description). The summary of evidence is described through four categories to give the reader levels of confidence in the quality for the outcomes and interventions. The four hierarchal categories mimic the GRADE conclusion definitions (Oxman and GRADE Working Group 2004):

- High - Further research is very unlikely to change our confidence in the estimate of effect or accuracy.

- Moderate - Further research is likely to have an important impact on our confidence in the estimate of effect or accuracy and may change the estimate.

- Low - Further research is very likely to have an important impact on our confidence in the estimate of effect or accuracy and is likely to change the estimate.

- Very low - Any estimate of effect or accuracy is very uncertain.

2.6 CONTINGENCY ANALYSIS AND DEVIATIONS FROM THE PROTOCOL

Considerations for missing data and meta-analysis techniques are described in the protocol; however, the low quality research designs identified and included in the review undermined the relevance of meta-analysis and therefore most contingency measures. Procedures to address unit of analysis issues, independent findings, economic synthesis, use of weighted average, pooled effect, forest plots and funnel plots are found in the protocol (Yates, Vijcic, et al., 2015) but not further described here because they were not used in the review. Formal heterogeneity analysis with $\mathrm{I}^{2}$ could not be completed as reported outcomes were too different for direct comparison. Finally, the initial eight WASH intervention categories were expanded to 10 interventions and the intervention quality assessment was slightly adjusted from the protocol.

Case-control studies focusing on disease risk factors are not included in the main review, as cholera or other diseases were the outcomes (and as such well described) and the WASH interventions identified as significant (or not) are input variables, and self-reported and poorly described in the studies. A separate systematic review was conducted, summarizing cholera risk factors (See Box, 'Cholera case-control study review example', p. 6). 
The anticipated comparisons described in the protocol are also undermined by the lack of data quality and could not be carried out. The WASH interventions are not targeted to a specific gender, age range or other demographic along the PROGRESS-Plus subgroups. ${ }^{6}$ Additionally, the intervention setting (urban, rural, per-urban) is not always reported, and with some interventions covering a wide geographic area to large populations, it was not possible to compare across intervention setting.

${ }^{6}$ Place of residence, ethnicity, occupation, gender, religion, education, social capital, socioeconomic position, age, disability, sexual orientation, other vulnerable groups. Kavanagh, J., Oliver, S., Lorenc, T. Reflections on developing and using PROGRESS-Plus. Equity Update. 2008;2:1-3. 
In this section, a general overview of the review findings is presented, followed by detailed results by WASH intervention in Sections 3.1 to 3.5. Several interventions related to outbreak response are briefly described in Section 3.6 and economic analysis results are presented in Section 3.7. Lastly, a summary of interventions and a revisit to the theory of change modelling is included in Section 3.8.

Overall, 15,026 documents were identified in the systematic review process, including 37 review documents (Figure 3.1). After applying the three selection filters, 47 studies describing evaluations with 51 relevant contexts were included. In September 2016, database searches were re-run for recent publications, but no additional studies were identified for inclusion.

Figure 3.1: Screening process. Source: The research team

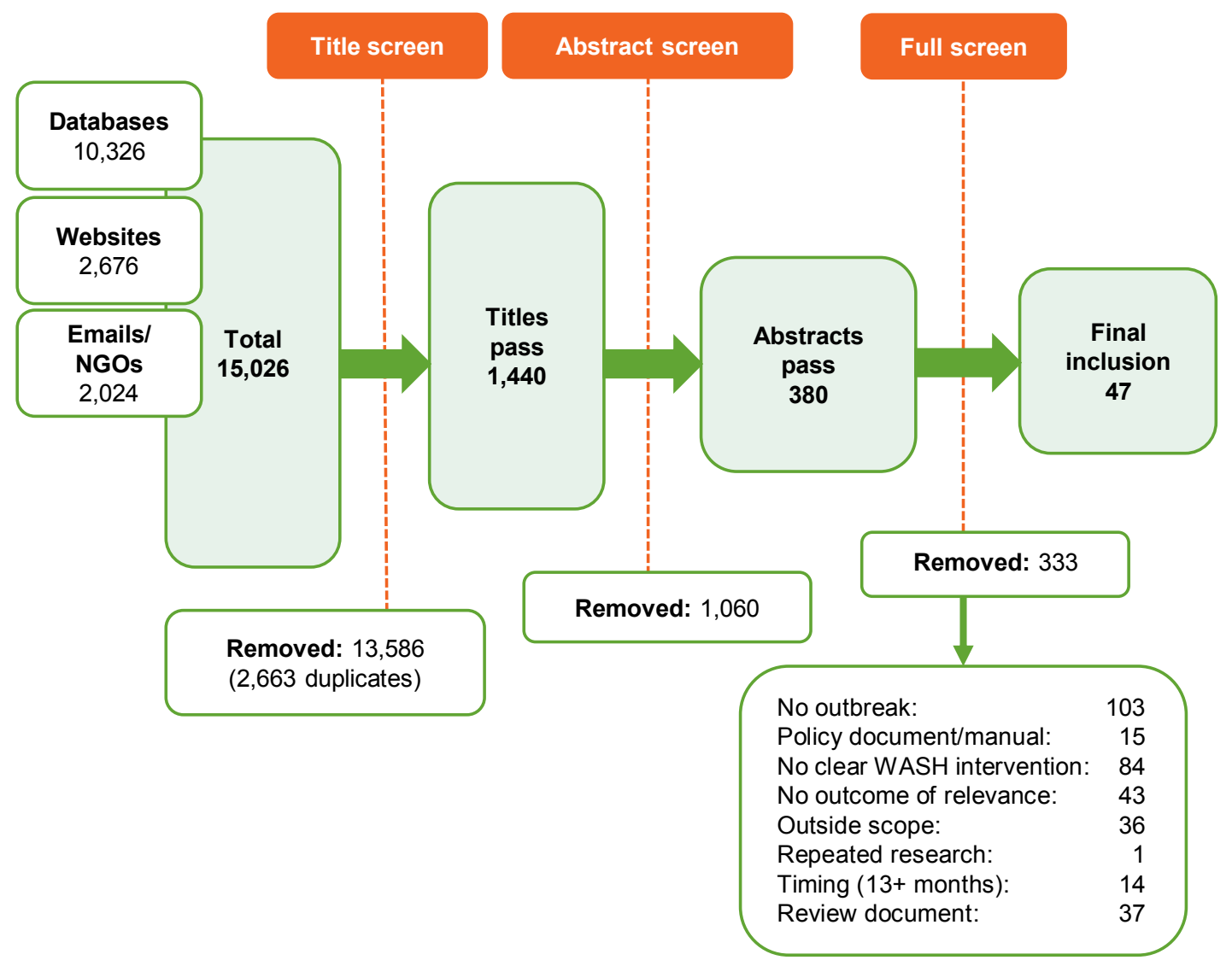

The included studies are summarized for comparison in tabular format in Appendix A.

The included studies describe WASH interventions in 19 countries, with the highest frequency of evaluations from Zimbabwe and Haiti. Cholera is the most researched and discussed disease, representing 86 percent $(44 / 51)$ of the diseases responded to in the included evaluations; Ebola (2, 4\%), acute watery diarrhoea $(3,6 \%)$, shigellosis $(1,2 \%)$ and typhoid fever $(1,2 \%)$ make up the other diseases evaluated. 
Figure 3.2: WASH component summary. Source: The research team

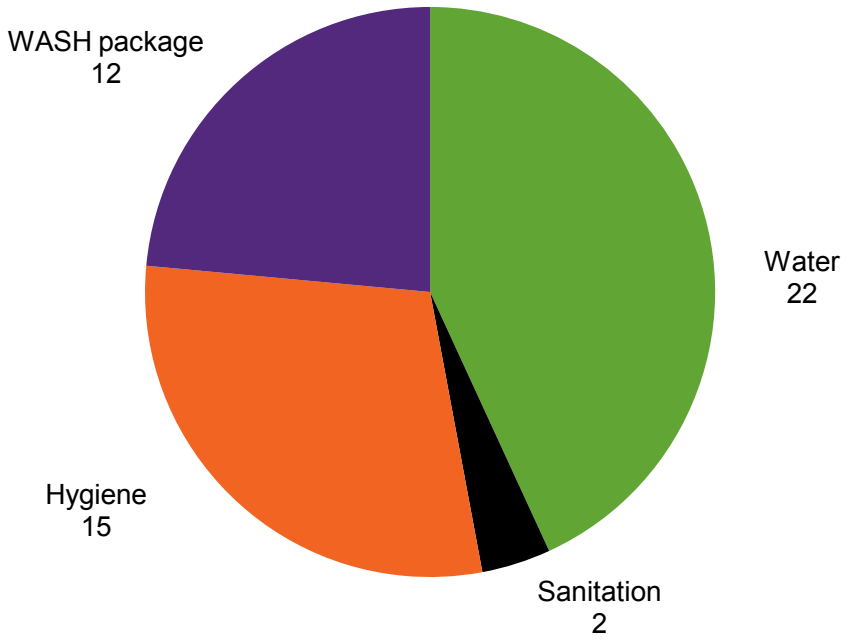

Water interventions represent the largest grouping of included evaluations ( $n=22,43 \%)$, followed by hygiene $(n=15,29 \%)$ and WASH package $(n=12,24 \%)$ (Figure 3.3). Sanitation interventions are represented by only two evaluations (4\%) (Figure 3.2).

A near equal number of evaluations were identified from the peer-reviewed $(26,51 \%)$ and grey literature $(n=25,49 \%)$ (Figure 3.3). Although the overall number of evaluations is nearly equal between published and grey literature, differences are seen by intervention, with water having more published evaluations and hygiene and WASH package having more grey literature evaluations.

Figure 3.3: Included studies by intervention, evaluation and publication

\begin{tabular}{|l|c|c|c|c|}
\hline \multicolumn{1}{|c|}{ Intervention (number) } & Quantitative & Qualitative & $\begin{array}{c}\text { Field } \\
\text { commentary }\end{array}$ & $\begin{array}{c}\text { Published or } \\
\text { grey literature } \\
\text { (P:G) }\end{array}$ \\
\hline Water & $\mathbf{1 9}$ & $\mathbf{2}$ & $\mathbf{1}$ & $\mathbf{1 8 : 4}$ \\
\hline Well disinfection (5) & 2 & 2 & 1 & $5: 0$ \\
\hline Source-based treatment (3) & 3 & 0 & 0 & $3: 0$ \\
\hline HWT - chlorine-based products (10) & 10 & 0 & 0 & $6: 4$ \\
\hline HWT - other products (4) & 4 & 0 & 0 & $4: 0$ \\
\hline Sanitation & $\mathbf{1}$ & $\mathbf{0}$ & $\mathbf{1}$ & $\mathbf{1 : 1}$ \\
\hline Community-driven sanitation (2) & 1 & 0 & 1 & $1: 1$ \\
\hline Hygiene & $\mathbf{5}$ & $\mathbf{4}$ & $\mathbf{6}$ & $\mathbf{7 : 8}$ \\
\hline Hygiene promotion (7) & 3 & 1 & 3 & $4: 3$ \\
\hline Social mobilization (3) & 0 & 1 & 2 & $0: 3$ \\
\hline Hygiene kit distribution (1) & 1 & 0 & 0 & $0: 1$ \\
\hline Environmental hygiene (4) & 1 & 2 & 1 & $3: 1$ \\
\hline WASH package & $\mathbf{0}$ & $\mathbf{3}$ & $\mathbf{9}$ & $\mathbf{0 : 1 2}$ \\
\hline WASH package (12) & 0 & 3 & 9 & $0: 12$ \\
\hline Totals & $\mathbf{2 5}$ & $\mathbf{9}$ & $\mathbf{1 7}$ & $\mathbf{2 6 : 2 5}$ \\
\hline
\end{tabular}

Note: studies are allocated to one category in the figure to avoid double-counting, but may be in more than one category when described below.

The majority of the evaluations $(70 \%, 38 / 51)$ have a high risk of bias (Figure 3.4$)$. The quantitative studies are mostly completed on water interventions, are more likely to be published and have less risk of bias. For example, published water evaluations are 47 percent low risk of bias (9/19), while no other WASH interventions have a low risk evaluation (0/32). Conversely, the WASH package evaluations are field commentary, unpublished, high risk of bias evaluations. The risk of bias for each evaluation is documented in Appendix D. 
Figure 3.4: Risk of bias summary. Source: The research team

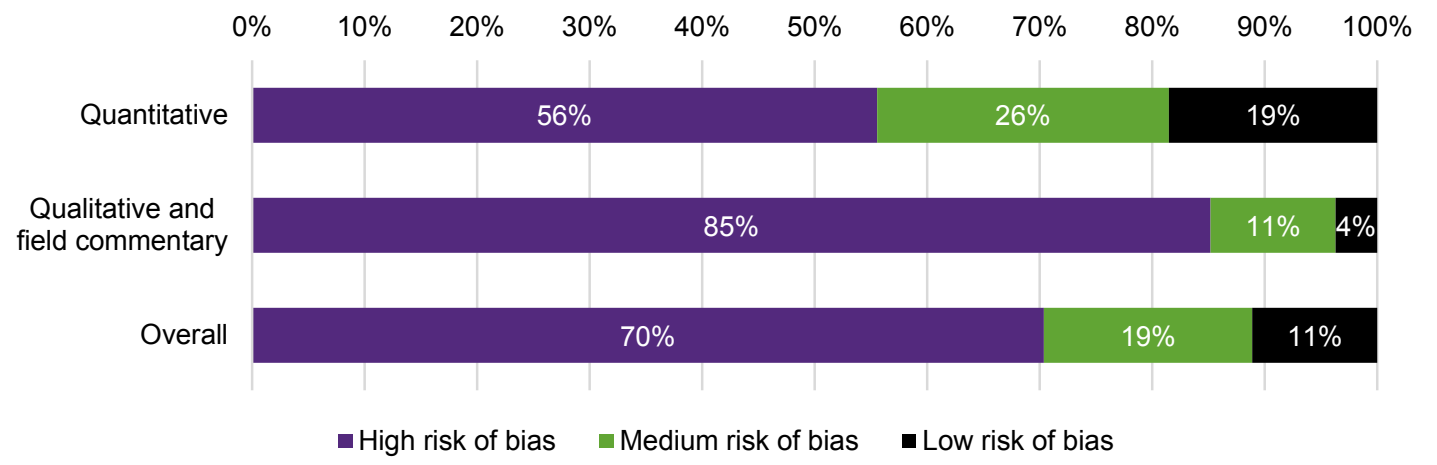

Overall, the study designs are weak, as only 14 percent of studies $(7 / 51)$ have any type of control group and less than 4 percent $(2 / 51)$ are RCTs. Diversity of outcomes is also weak, with measured health impacts in only six $(12 \%)$ of the interventions, and use is focused toward HWT interventions.

\section{Sensitivity}

The body of included evidence was sensitive to evaluation design, implementing organization and grey literature. The review is sensitive to the inclusion of low quality research designs; if they were not included the review would be limited to HWT studies, leaving the other eight interventions identified with no evidence. While studies were conducted by organizations varying from local governments to university (academics), most $(80 \%, 41)$ were by NGOs. Overall, at least 27 different agencies had provided documents that were reviewed in the identification process; however, ACF and Oxfam contributed the largest amount of studies in the identification process. This is represented in the included studies, of which documents submitted from these two organizations account for 45 percent (23) - a substantial portion of the evidence base. Lastly, grey literature contributes to nearly half $(49 \%, 25 / 51)$ of the included studies. These factors are fundamental to the review, and as such sensitivity was not investigated by individual intervention or outcome.

\section{WATER: SOURCE-BASED INTERVENTIONS}

The source-based interventions of well disinfection and chlorine dispensers are assessed in six studies in eight contexts. While well rehabilitation and water trucking were listed as outbreak activities in some documents, none of the included evaluations assess these activities.

\section{Well disinfection}

Disinfecting a contaminated well with chlorine is a common intervention in outbreak response, and is achieved through shock or pot chlorination.

- Shock chlorination - A single dose of chlorine is added directly into the well, intended to quickly clean the well. The well can be, but is not always, closed for several hours to one day to allow the chlorine to dissipate.

- Pot chlorination - A porous container filled with sand and powdered chlorine is inserted in a well, intended to slowly disperse chlorine and treat water over an extended time.

Five evaluations were identified that describe four slightly different approaches to well disinfection with chlorine (note that two studies evaluated multiple methods) (Figure 3.5):

1 a shock dose of liquid chlorine (bleach)

2 pot chlorination with powdered chlorine, sand and gravel in a pierced jerry can 
3 pot chlorination with locally pressed chlorine tablets in a perforated container

4 floating pot chlorinator (commercial plastic mushroom-shaped device used with swimming pools).

All of these approaches require an understanding of chlorine dose with respect to chlorine concentration and water volume. The amount of organic content and withdrawn water also impact the amount of chlorine needed for treatment. Ideally, the FCR for water treatment would be greater than or equal to $0.2 \mathrm{mg} / \mathrm{L}$ and less than or equal to $2.0 \mathrm{mg} / \mathrm{L}-$ which is the range ensuring water treatment but not exceeding taste or guideline thresholds.

\section{Figure 3.5: Well disinfection comparison. Source: The research team}

\begin{tabular}{|c|c|c|c|}
\hline $\begin{array}{l}\text { Author (year) } \\
\text { Country } \\
\text { Bias }\end{array}$ & $\begin{array}{l}\text { Context } \\
\text { Approach }\end{array}$ & Evaluation & Findings \\
\hline $\begin{array}{l}\text { Rowe (1998) } \\
\text { Guinea-Bissau } \\
\text { High risk }\end{array}$ & $\begin{array}{l}\text { Outbreak cholera - Urban } \\
\text { 1) Liquid chlorine: bleach added } \\
\text { to achieve } 30 \mathrm{mg} / \mathrm{L} \text { in well }\end{array}$ & $\begin{array}{l}\text { Cross-sectional } 10 \\
\text { shallow (hand dug) wells } \\
\text { monitored every } 24 \\
\text { hours until FCR } \\
\text { degraded }\end{array}$ & $\begin{array}{l}40 \% \text { of wells had FCR } \\
>0 \mathrm{mg} / \mathrm{L} \text { after } 24 \text { hours } \\
\text { (median } 24 \text { hours; range } \\
0-6 \text { days) }\end{array}$ \\
\hline $\begin{array}{l}\text { Libessart } \\
(2000) \\
\text { Somalia } \\
\text { High risk }\end{array}$ & $\begin{array}{l}\text { Endemic cholera - Urban - } \\
\text { internally displaced persons (IDP) } \\
\text { 1) Liquid chlorine: } 1 \% \text { chlorine } \\
\text { solution } \\
\text { 2) Pot chlorination: } 5 \mathrm{~L} \text { jerry can } \\
\text { with gravel, sand and chlorine } \\
\text { layers (chlorine not described). } \\
\text { 3) Pressed chlorine tablets: } 125 \mathrm{~g} \\
\text { of high test hypochlorite (HTH) } \\
\text { (75\% chlorine) pressed into a } \\
\text { tablet, inserted into a pierced pipe }\end{array}$ & $\begin{array}{l}\text { Cross-sectional FCR } \\
\text { measured at different } \\
\text { times over several } \\
\text { programming cycles: } 1 \text { ) } \\
1 \% \text { liquid chlorine: } 173 \\
\text { wells over } 1 \text { year; } 2 \text { ) } \\
\text { Jerry can pot } \\
\text { chlorination: } 919 \text { tests } \\
\text { over } 3 \text { months; } 3 \text { ) } \\
\text { Pressed tablet pot } \\
\text { chlorination: } 98 \text { tests } \\
\text { (duration not reported) }\end{array}$ & $\begin{array}{l}\text { 1) } 69 \% \text { of sample had } \\
\text { FCR }>0 \mathrm{mg} / \mathrm{L} ; \mathrm{n}=178 \\
\text { samples. FCR lasted } \\
\text { about an hour } \\
\text { 2) } 87 \% \text { of sample had } \\
\text { FCR }>0 \mathrm{mg} / \mathrm{L} ; \mathrm{n}=919 \\
\text { samples } \\
\text { 3) } 94 \% \text { of sample had } \\
\text { FCR }>0 \mathrm{mg} / \mathrm{L} ; \mathrm{n}=98 \\
\text { samples }\end{array}$ \\
\hline $\begin{array}{l}\text { Garandeau } \\
(2006) \\
\text { Liberia } \\
\text { High risk }\end{array}$ & $\begin{array}{l}\text { Cholera - Peri-urban - IDPs } \\
\text { 1) Liquid chlorine: } 5 \% \text { chlorine } \\
\text { bleach, twice per day. } \\
\text { 2) Pot chlorination: } 4 \mathrm{~L} \text { jerry can } \\
\text { with gravel, sand and powdered } \\
\text { chlorine layers ( } 0.5 \mathrm{~L} \text { calcium } \\
\text { hypochlorite granules, } 65 \% \\
\text { chlorine) } \\
\text { 3) Pot chlorination with pressed } \\
\text { chlorine tablets: } 70 \mathrm{~g} \text { calcium } \\
\text { hypochlorite ( } 65 \% \text { chlorine) } \\
\text { pressed into a tablet, } 1-2 \text { tablets } \\
\text { suspended in a pierced plastic } \\
\text { bag with } 2 \mathrm{~L} \text { of sand } \\
\text { 4) Floating pot chlorinator: } \\
\text { Floating pool chlorinator, } 200 \mathrm{~g} \\
\text { trichloroisocyanuric acid tablets }\end{array}$ & $\begin{array}{l}\text { Cross-sectional } \\
12 \text { hand dug wells ( } 3 \\
\text { protected and } 9 \\
\text { unprotected) used over } \\
9 \text { weeks with different } \\
\text { chlorination techniques, } \\
\text { FCR measured }\end{array}$ & $\begin{array}{l}\text { 1) FCR was }>0.2 \mathrm{mg} / \mathrm{L} \text { for } \\
\text { less than } 1 \text { day. } \\
\text { 2) Chlorine granules } \\
\text { dissolved too quickly, } \\
\text { spiking the well up fast } \\
\text { (FCR up to } 10 \mathrm{mg} / \mathrm{L}) \\
\text { 3) FCR stable between } \\
0.2-1.0 \mathrm{mg} / \mathrm{L} \text { in all wells } \\
\text { for } 3-6 \text { days } \\
\text { 4) FCR could be stable } \\
\text { with close monitoring but } \\
\text { pots not locally available } \\
\text { and interfered with } \\
\text { drawing water }\end{array}$ \\
\hline $\begin{array}{l}\text { Guevart } \\
(2008) \\
\text { Cameroon } \\
\text { Low risk }\end{array}$ & $\begin{array}{l}\text { Cholera outbreak - Urban } \\
\text { 1) Pot chlorination (with } \\
\text { perforated bag), including } \\
\text { powdered chlorine (calcium } \\
\text { hypochlorite, } 70 \% \text { chlorine) and } \\
\sim 1 \mathrm{~kg} \text { sand }\end{array}$ & $\begin{array}{l}\text { Cross-sectional } \\
18 \text { wells ( } 2 \text { villages - } 9 \\
\text { wells each) } 36 \\
\text { chlorinations - FCR } \\
\text { measured daily }\end{array}$ & $\begin{array}{l}\text { FCR remained }>0.2 \mathrm{mg} / \mathrm{L} \\
\text { for } 3 \text { days, after } 4 \text { days } \\
\text { half of the wells were } \\
<0.2 \mathrm{mg} / \mathrm{L}\end{array}$ \\
\hline $\begin{array}{l}\text { Cavallaro } \\
(2011) \\
\text { Guinea-Bissau } \\
\text { Low risk }\end{array}$ & $\begin{array}{l}\text { Cholera outbreak - Urban and } \\
\text { rural } \\
\text { 1) Pot chlorination in } 1.5 \mathrm{~L} \text { plastic } \\
\text { bottle with gravel, sand and } \mathrm{HTH} \text {, } \\
15 \mathrm{~g} \text { per } 1,000 \mathrm{~L} \text { of well water }(70 \% \\
\text { chlorine) }\end{array}$ & $\begin{array}{l}\text { Cross-sectional } \\
30 \text { wells - FCR and } \\
\text { TCR measured daily for } \\
1-3 \text { days after inserting } \\
\text { chlorinator }\end{array}$ & $\begin{array}{l}\text { FCR was }>0 \mathrm{mg} / \mathrm{L} \text { FCR in } \\
73 \% \text { of wells }(19 / 26) \text { after } \\
24 \text { hours; } 42 \%(11) \\
>0 \mathrm{mg} / \mathrm{L} \text { after } 48 \text { hours; } \\
31 \%(8) \text { after } 72 \text { hours }\end{array}$ \\
\hline
\end{tabular}


While all five evaluations describe well disinfection, the approach and sampling varies and thus evaluations are heterogeneous. Additionally, beneficiary use, soil and well conditions could influence results, but are not sufficiently described for sub-group comparisons. Results are described by three variations of pot chlorination (traditional, floating pot and pressed tablet) and shock chlorination.

Traditional pot chlorination - Pot chlorination with pierced jerry cans had mixed results, but did have the negative effect of spiking wells in Liberia to levels approaching 10mg/L. Pot chlorination in Somalia and Cameroon did not report spikes, but also did not detail the time frame for FCR levels. A small 1.5L pot chlorinator had limited success in Guinea-Bissau with 73 percent of wells maintaining FCR for 24 hours, and 31 percent for three days or more (Cavallaro et al., 2011). Pot chlorination was successful in providing consistent FCR for three days in Cameroon (Guevart et al., 2008), which is similar to results seen in a pot chlorination intervention in Angola that was not outbreak related and not included in the review, but did reduce microbiological contamination in wells (Godfrey et al., 2003).

Floating pot chlorinator - Floating pot chlorinators could provide consistent chlorine residual, but required regular adjustments and were not locally available.

Pressed tablet pot chlorination - Calcium hypochlorite pressed into HTH tablets are assessed as the best well treatment option by implementing agencies in both comparative evaluations (Garandeau, Trevett, and Bastable, 2006; Libessart and Hammache, 2000). Pressed tablets were locally made and maintained appropriate levels of FCR for 3-4 days.

Shock chlorination - Single and regular repeated doses of liquid chlorine solution are consistently determined by studies to be ineffective at maintaining FCR for more than a few hours (Rowe et al., 1998; Libessart and Hammache, 2000; Garandeau et al., 2006). The chlorine residual lasted only a short time, yet the community perceived (when asked) that a single dose of chlorine would protect the well for up to six months (Rowe et al., 1998).

\section{Well disinfection summary}

Shock chlorination did not provide residual protection for more than a few hours. Traditional pot chlorination inconsistently maintained measurable FCR for 1-4 days. In comparative evaluations both with high risk of bias, pressed $\mathrm{HTH}$ tablets in pot chlorination maintained FCR for 3-4 days and was the preferred mode of well disinfection by the implementing organizations (Figure 3.6). Despite variations in interventions and sampling strategies, conclusions are consistent for traditional pot chlorination, pressed tablets and shock chlorination. The disconnect between community perception and actual safe water noted in one study is an important consideration for any well disinfection intervention.

Figure 3.6: Well disinfection summary

\begin{tabular}{|l|l|l|l|}
\hline Outcomes & $\begin{array}{l}\text { Number of } \\
\text { studies }\end{array}$ & $\begin{array}{l}\text { Quality of } \\
\text { evidence }\end{array}$ & Summary \\
\hline Health & - & - & - \\
\hline Use & - & - & - \\
\hline $\begin{array}{l}\text { Barriers and } \\
\text { facilitators }\end{array}$ & 5 & Moderate & $\begin{array}{l}\text { Variations in interventions and different sampling method but } \\
\text { conclusions were consistent for each treatment group } \\
\text { Pot chlorination was evaluated with four studies of high and } \\
\text { low quality, maintaining FCR for 1-4 days } \\
\text { Pressed chlorine tablets pot chlorination was evaluated by two } \\
\text { studies of low quality but was preferred by implementing } \\
\text { agencies in comparative studies because FCR was } \\
\text { maintained for 3-4 days } \\
\text { Liquid chlorine interventions consistently provided FCR for } \\
\text { less than one day }\end{array}$ \\
\hline
\end{tabular}




\section{Source-based treatment}

Source-based treatment is water treatment that occurs at the source itself. Chlorine dispensers and bucket chlorination are two source-based water treatment interventions used in outbreak response.

- Chlorine dispensers - A chlorine 'dispenser' programme includes hardware installed next to a water source that dispenses chlorine solution, a local 'promoter' who refills the dispenser and conducts community education and a supply chain of chlorine refills. Users treat water by turning a valve that dispenses a controlled amount of chlorine solution.

- Bucket chlorination - A person is stationed near a water source and adds a known dose of chlorine directly into the recipient's water collection container.

Evaluations were identified in the review only for dispensers. Dispensers were used in three different cholera contexts: Haiti, Sierra Leone and Democratic Republic of Congo (DRC) with three different NGOs (Yates, Armitage, et al., 2015). Results over two acute evaluations (2-8 weeks after installation) and three sustained evaluations (4-7 months after installation) focused on reported use, confirmed use and effective use (Figure 3.7). Spillover effects from other water treatment options were present and assist in explaining results, as the municipal water system in DRC was functional in the sustained evaluation and 32 percent of households in Haiti reported using chlorine tablets, which is an alternative treatment method. Through regression analysis of household survey data, speaking to the promoter within the last month and collecting water from a source with a dispenser are factors consistently associated with higher use across the different contexts.

Figure 3.7: Source-based treatment comparison

\begin{tabular}{|c|c|c|c|c|c|}
\hline \multirow{2}{*}{$\begin{array}{l}\text { Author (year) } \\
\text { Country } \\
\text { Bias }\end{array}$} & \multirow{2}{*}{$\begin{array}{l}\text { Context } \\
\text { Approach }\end{array}$} & \multirow[t]{2}{*}{ Evaluation } & \multicolumn{3}{|c|}{ Use outcomes } \\
\hline & & & $\begin{array}{c}\text { Reported } \\
\text { use }\end{array}$ & $\begin{array}{c}\text { Confirmed } \\
\text { use }\end{array}$ & $\begin{array}{c}\text { Effective } \\
\text { use }\end{array}$ \\
\hline \multirow{2}{*}{$\begin{array}{l}\text { Yates, } \\
\text { Armitage } \\
(2015) \\
\text { Haiti } \\
\text { Low risk of } \\
\text { bias }\end{array}$} & \multirow{2}{*}{$\begin{array}{l}\text { Cholera outbreak - } \\
\text { Rural } \\
60 \text { dispenser sites } \\
20 \mathrm{~L} \text { and } 5 \mathrm{~L} \text { dose per } \\
\text { site } \\
1 \text { promoter/site }\end{array}$} & \multirow{2}{*}{$\begin{array}{l}\text { Cross-sectional } \\
\text { (cluster) } \\
298 \text { households }(\mathrm{HH})\end{array}$} & \multicolumn{3}{|c|}{ Sustained } \\
\hline & & & $55 \%$ & $9 \%$ & $4 \%$ \\
\hline \multirow{4}{*}{$\begin{array}{l}\text { Yates, } \\
\text { Armitage } \\
(2015) \\
\text { Sierra Leone } \\
\text { Low risk of } \\
\text { bias }\end{array}$} & \multirow{4}{*}{$\begin{array}{l}\text { Cholera outbreak - } \\
\text { Peri-urban } \\
50 \text { dispenser sites } \\
20 \text { L dose per site } \\
32 \text { promoters } / 50 \text { sites }\end{array}$} & \multirow{4}{*}{$\begin{array}{l}\text { Cross-sectional } \\
\text { (cluster) } \\
300 \mathrm{HH} \text { (initial and } \\
\text { sustained) }\end{array}$} & \multicolumn{3}{|c|}{ Initial } \\
\hline & & & $26 \%$ & $11 \%$ & $10 \%$ \\
\hline & & & & Sustained & \\
\hline & & & $31 \%$ & $18 \%$ & $10 \%$ \\
\hline \multirow{2}{*}{$\begin{array}{l}\text { Yates, } \\
\text { Armitage } \\
(2015)\end{array}$} & \multirow{4}{*}{$\begin{array}{l}\text { Endemic cholera - } \\
\text { Rural and peri-urban } \\
100 \text { dispenser sites } \\
2-20 \mathrm{~L} \text { doses per site } \\
1 \text { promoter/site }\end{array}$} & \multirow{4}{*}{$\begin{array}{l}\text { Cross-sectional } \\
\text { (cluster) } \\
300 \mathrm{HH} \text { (initial and } \\
\text { sustained) }\end{array}$} & \multicolumn{3}{|c|}{ Initial } \\
\hline & & & $76 \%$ & $34 \%$ & $28 \%$ \\
\hline \multirow{2}{*}{$\begin{array}{l}\text { DRC } \\
\text { Low risk of } \\
\text { bias }\end{array}$} & & & \multicolumn{3}{|c|}{ Sustained } \\
\hline & & & $75 \%$ & $5 \%$ & $0 \%$ \\
\hline
\end{tabular}

A fourth case study in the same evaluation was conducted in a non-outbreak situation, and had much higher results (>79\% reported use, confirmed use and effective use in initial and sustained evaluations). Acknowledging the low effective use rates in Figure 3.7, the three implementing organizations gathered at project end and reflected on factors that led to success. These included: 1 ) appropriate source selection; 2 ) chlorine solution quality and supply chain; 3 ) dispenser hardware installation and maintenance; 4) integration into a larger WASH programme; 5) promoter recruitment and remuneration; 6 ) experienced programme staff; 7) partnering with local organizations; 8) conducting ongoing monitoring; and 9) having a sustainability plan. 


\section{Source-based treatment summary}

Use rates varied, but dispensers are deemed to be an appropriate option if the certain contextual conditions, discussed previously, are met (Figure 3.8). Through low risk studies, promotion and access are consistently significant factors in use of the dispensers.

\section{Figure 3.8: Source-based treatment summary}

\begin{tabular}{|l|l|l|l|}
\hline Outcomes & $\begin{array}{l}\text { Number of } \\
\text { studies }\end{array}$ & $\begin{array}{l}\text { Quality of } \\
\text { evidence }\end{array}$ & Summary \\
\hline Health & - & - & - \\
\hline Use & 3 & Moderate & $\begin{array}{l}\text { Variation in reported, confirmed and effective use - context } \\
\text { specific, promotion and accessibility as factors }\end{array}$ \\
\hline $\begin{array}{l}\text { Barriers and } \\
\text { facilitators }\end{array}$ & 3 & Moderate & $\begin{array}{l}\text { Speaking with promoter and easy access to dispenser } \\
\text { associated with higher use }\end{array}$ \\
\hline
\end{tabular}

\section{WATER: HOUSEHOLD WATER TREATMENT AND SAFE} STORAGE

HWT products (also called point-of-use water treatment products) are interventions used in the home to improve the microbiological quality of household drinking water. These may be distributed as a sole intervention or included as one of several items in a hygiene kit. Distributions also sometimes include hygiene promotion.

Household water treatment - HWT products (chlorine products, filters, solar disinfection and boiling) disinfect, remove or inactivate harmful pathogens. HWT products are used at home, relying on the beneficiary to understand instructions and use materials correctly.

Hygiene kit distributions - Hygiene kits, a type of non-food items (NFI) distribution, provide outbreak-affected populations with materials to reduce the risks of disease transmission. HWT products, soap, water storage containers and household disinfection materials are commonly included items in hygiene kits.

Hygiene promotion - Hygiene promotion related to HWT products typically include printed instructions on how to use a product or a community health worker giving a lesson on correct use. Community health workers may also share outbreak-related information.

HWT is the most studied intervention with 16 evaluations, some of which use multiple products. Overall, ten used chlorine-based products (six with chlorine tablets, four with liquid chlorine), three used flocculant/disinfectants, two used filters, one used solar disinfection and one used boiling. Additionally, safe storage of water was evaluated in two evaluations.

\section{HWT - chlorine-based products}

Chlorine is often distributed in outbreak response, particularly in cholera response, because it effectively inactivates most bacterial and viral pathogens, leads to residual protection, is low cost and is easy to use and transport. Users add one tablet or measured amount of liquid (usually 1 capful) to low-turbidity water, wait 30 minutes and drink. Higher turbidity water can be treated by doubling the dose. There are two chlorine-based HWT options used in outbreaks: tablets and liquid.

- Chlorine tablets - Small tablets of $7-167 \mathrm{mg}$ sodium dichloroisocyanurate used to treat $1-20 \mathrm{~L}$ of water (e.g. Aquatabs $\left.{ }^{\circledR}\right)$.

- Liquid chlorine - Either a small bottle of 1-1.25 percent sodium hypochlorite, sized so one cap is used to treat $20 \mathrm{~L}$ of water (e.g. WaterGuard) or commercial bleach, where the dosage is generally in drops. 
Note: combination flocculant/disinfectants also use chlorine to disinfect drinking water, but have another chemical agent to reduce turbidity. For this review, combination flocculant/disinfectants are also considered within the HWT - chlorine-based products category and described further below in a dedicated sub-section.

Reported use, confirmed use and effective use are all outcome metrics reported for chlorinebased HWT options. Among the nine chorine-based evaluations, eight measure reported use, eight measure confirmed use and seven report both. Effective use is measured in one evaluation. Individual assessments of chlorine tablets and liquid chlorine are separated for further analysis in the following sections.

\section{Chlorine tablets}

Chlorine tablets were used in six evaluated contexts (Figure 3.10). The free distribution of chlorine tablets was through a hygiene kit in all contexts. The distributed tablets (67-167mg) were intended to treat 10-20L of water. Evaluations included both reported and confirmed use in five out of six contexts (Figure 3.9). The reported use ranges between 8 and 31 percent, while confirmed use ranges between 7 and 87 percent with a noticeable outlier Figure 3.9). The heterogeneity of context, intervention and evaluation was too high to calculate summary statistics or conduct meta-analysis.

Figure 3.9: Chlorine tablet evaluations with reported and confirmed use. Source: The research team

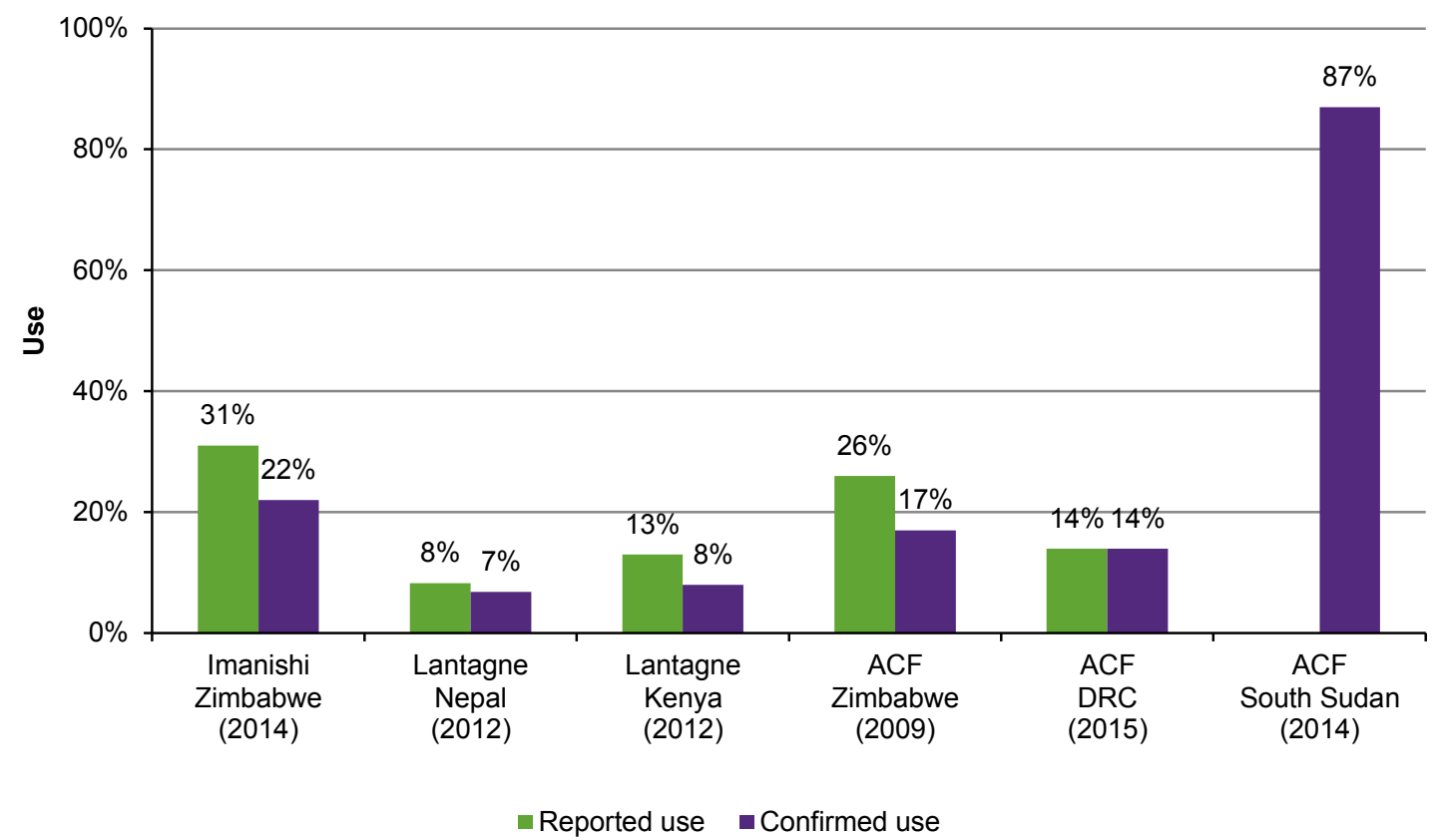

The noticeable outlier is a grey literature evaluation with a high risk of bias from a cholera response in South Sudan (ACF 2014a). A possible explanation for the outlier is that hygiene promotion was conducted before the distribution of the HWT products, and as such the beneficiary population reported high cholera knowledge. Overall, 92 percent of households reported a visit before the hygiene kits distribution and 84 percent reported attending an awareness session; additionally, 82 percent of households reported that drinking chlorinated water prevents cholera. The evaluation was also 1-3 weeks after distribution, which could explain higher recall and use. 
Figure 3.10: Chlorine tablet comparison

\begin{tabular}{|c|c|c|c|c|}
\hline \multirow{2}{*}{$\begin{array}{l}\text { Author (Year) } \\
\text { Country } \\
\text { Bias }\end{array}$} & \multirow{2}{*}{$\begin{array}{l}\text { Context } \\
\text { Approach }\end{array}$} & \multirow[t]{2}{*}{ Evaluation } & \multicolumn{2}{|l|}{ Findings } \\
\hline & & & $\begin{array}{l}\text { Reported } \\
\text { use }\end{array}$ & $\begin{array}{l}\text { Confirmed } \\
\text { use }\end{array}$ \\
\hline $\begin{array}{l}\text { Imanishi (2014) } \\
\text { Zimbabwe } \\
\text { Medium risk of } \\
\text { bias }\end{array}$ & $\begin{array}{l}\text { Cholera outbreak - Large geographic area } \\
\text { Three chlorine tablets distributed by } \\
\text { different organizations: Oasis } 67 \mathrm{mg} \text {, } \\
\text { Aquatabs } 67 \mathrm{mg} \text {, Aquatabs } 167 \mathrm{mg} \text { in } \\
\text { hygiene kits with door-to-door promotion } \\
\text { and information, education and } \\
\text { communication materials to } 51,000 \mathrm{HH}\end{array}$ & $\begin{array}{l}\text { Cross-sectional } \\
458 \mathrm{HH}\end{array}$ & $\begin{array}{l}31 \% \text { of } \mathrm{HH} \\
\text { reported } \\
\text { use }\end{array}$ & $\begin{array}{l}22 \% \text { of } \mathrm{HH} \\
\text { confirmed } \\
\text { use }(\mathrm{FCR} \\
>0.0 \mathrm{mg} / \mathrm{L})\end{array}$ \\
\hline $\begin{array}{l}\text { Lantagne }(2012) \\
\text { Nepal } \\
\text { Low risk of bias }\end{array}$ & $\begin{array}{l}\text { Cholera outbreak - Extreme rural } \\
\text { Local NGOs using pre-positioned hygiene } \\
\text { kits. } 1,565 \mathrm{HH} \text { received Aquatabs } ® \text { and } \\
\text { also liquid chlorine (WaterGuard, Piyush) } \\
\text { with hygiene promotion }\end{array}$ & $\begin{array}{l}\text { Cross-sectional } \\
400 \mathrm{HH}\end{array}$ & $\begin{array}{l}8.3 \% \text { of } \mathrm{HH} \\
\text { reported } \\
\text { use }\end{array}$ & $\begin{array}{l}6.8 \% \text { of } \mathrm{HH} \\
\text { confirmed } \\
\text { use }(\mathrm{FCR} \\
\geq 0.2 \mathrm{mg} / \mathrm{L})\end{array}$ \\
\hline $\begin{array}{l}\text { Lantagne }(2012) \\
\text { Kenya } \\
\text { Low risk of bias }\end{array}$ & $\begin{array}{l}\text { Cholera and flooding - Extreme rural } \\
\text { Pre-positioned hygiene kits. Aquatabs }{ }^{\circledR} \\
\text { and PUR® Purifier of Water included to } \\
5,592 \mathrm{HH}\end{array}$ & $\begin{array}{l}\text { Cross-sectional } \\
409 \mathrm{HH}\end{array}$ & $\begin{array}{l}13 \% \text { of } \mathrm{HH} \\
\text { reported } \\
\text { use }\end{array}$ & $\begin{array}{l}7.9 \% \text { of } \mathrm{HH} \\
\text { confirmed } \\
\text { use (FCR } \\
\geq 0.2 \mathrm{mg} / \mathrm{L} \text { ) } \\
\text { (Effective } \\
\text { use: } 5.3 \% \\
\text { of } \mathrm{HH} \text { ) }\end{array}$ \\
\hline $\begin{array}{l}\text { ACF (2009) } \\
\text { Household } \\
\text { Zimbabwe } \\
\text { High risk of bias }\end{array}$ & $\begin{array}{l}\text { Cholera outbreak - Large geographic area } \\
\text { Aquatabs } ® \text { distributed } \mathrm{HH} \text { as part of an NFI } \\
\text { kit with bucket and lid }(\sim 33,000 \text { - kits, other } \\
\text { contents not described) }\end{array}$ & $\begin{array}{l}\text { Cross-sectional } \\
218 \mathrm{HH}\end{array}$ & $\begin{array}{l}26 \% \text { of } \mathrm{HH} \\
\text { reported } \\
\text { use }\end{array}$ & $\begin{array}{l}17 \% \text { of } \mathrm{HH} \\
\text { confirmed } \\
\text { use }(\mathrm{FCR} \\
>0.5 \mathrm{mg} / \mathrm{L})\end{array}$ \\
\hline $\begin{array}{l}\text { ACF - Tokplo } \\
(2015) \\
\text { DRC } \\
\text { High risk of bias }\end{array}$ & $\begin{array}{l}\text { Endemic outbreak - Large geographic area } \\
\text { Distribution of chloramine tablets in } \\
\text { hygiene kits with promotion to } 3,000 \mathrm{HH}\end{array}$ & $\begin{array}{l}\text { Cross-sectional } \\
384 \mathrm{HH}\end{array}$ & $\begin{array}{l}14 \% \text { of } \mathrm{HH} \\
\text { reported } \\
\text { use }\end{array}$ & $\begin{array}{l}14 \% \text { of } \mathrm{HH} \\
\text { confirmed } \\
\text { use (FCR } \\
0.3- \\
0.6 \mathrm{mg} / \mathrm{L})\end{array}$ \\
\hline $\begin{array}{l}\text { ACF }(2014) \\
\text { Hygiene kits } \\
\text { post distribution } \\
\text { monitoring } \\
\text { (PDM) report } \\
\text { South Sudan } \\
\text { High risk of bias }\end{array}$ & $\begin{array}{l}\text { Cholera outbreak - Large geographic area } \\
7,348 \text { hygiene kits with promotion } \\
\text { including: Aquatabs, filter cloth, PUR } \\
\text { packets and bucket }\end{array}$ & $\begin{array}{l}\text { Cross-sectional } \\
351 \mathrm{HH}\end{array}$ & $\begin{array}{l}\text { Reported } \\
\text { use not } \\
\text { measured }\end{array}$ & $\begin{array}{l}87 \% \text { of } \mathrm{HH} \\
\text { confirmed } \\
\text { use }(\mathrm{FCR} \\
>0.1 \mathrm{mg} / \mathrm{L})\end{array}$ \\
\hline
\end{tabular}

The taste and smell of chlorine tablets was reported as a barrier to use in five contexts within three countries (ACF, 2009; Lantagne and Clasen, 2012; Imanishi et al., 2014; Ruiz-Roman, 2009). Part of the reason for the taste and smell objections may have been confusion between the appropriate tablet dose and water storage container size, as some respondents did not have the appropriate water storage container for the tablet size distributed and this may have led to high doses and unfavourable taste (Imanishi et al., 2014; ACF, 2009). Additionally, sometimes multiple tablets were distributed, leading to confusion in users. Knowing an HWT method before the outbreak was an indicator of use in Zimbabwe (Imanishi et al., 2014) and Nepal (Lantagne and Clasen, 2012), where familiarity and easeof-use of chlorine tablets were also described.

\section{Chlorine tablet summary}

The quality of evidence for individual studies is mixed, but reported and confirmed use are consistently low, with one outlier with high bias (Figure 3.11). Hygiene promotion and alternative treatment methods could also factor into the low use. Although the simplicity and ease-of-use of tablets were appreciated, it is noted that having a storage container of appropriate size for the tablet is helpful and having multiple tablets distributed in the same emergency could be confusing. 
Figure 3.11: Chlorine tablet summary

\begin{tabular}{|l|l|l|l|}
\hline Outcomes & $\begin{array}{l}\text { Number of } \\
\text { studies }\end{array}$ & $\begin{array}{l}\text { Quality of } \\
\text { evidence }\end{array}$ & Summary \\
\hline Health & - & - & - \\
\hline Use & 6 & Moderate & $\begin{array}{l}\text { Reported use ranged between 8-31\% and confirmed use } \\
\text { ranged between 7-87\%; with the outlier from South Sudan } \\
\text { removed the range is 7-22\% }\end{array}$ \\
\hline $\begin{array}{l}\text { Barriers and } \\
\text { facilitators }\end{array}$ & 5 & Moderate & $\begin{array}{l}\text { Chlorine taste/smell, ease-of-use and familiarity influence use } \\
\text { and acceptance }\end{array}$ \\
\hline
\end{tabular}

\section{Liquid chlorine}

Liquid chlorine is evaluated in four contexts in three countries (Figure 3.13). Reported use ranges between 20 and 88 percent, and confirmed use ranges between 12 and 69 percent (Figure 3.12). As heterogeneity and bias of the studies is high, meta-analysis was not conducted.

\section{Figure 3.12: Liquid chlorine evaluations with reported and confirmed use. Source:} The research team

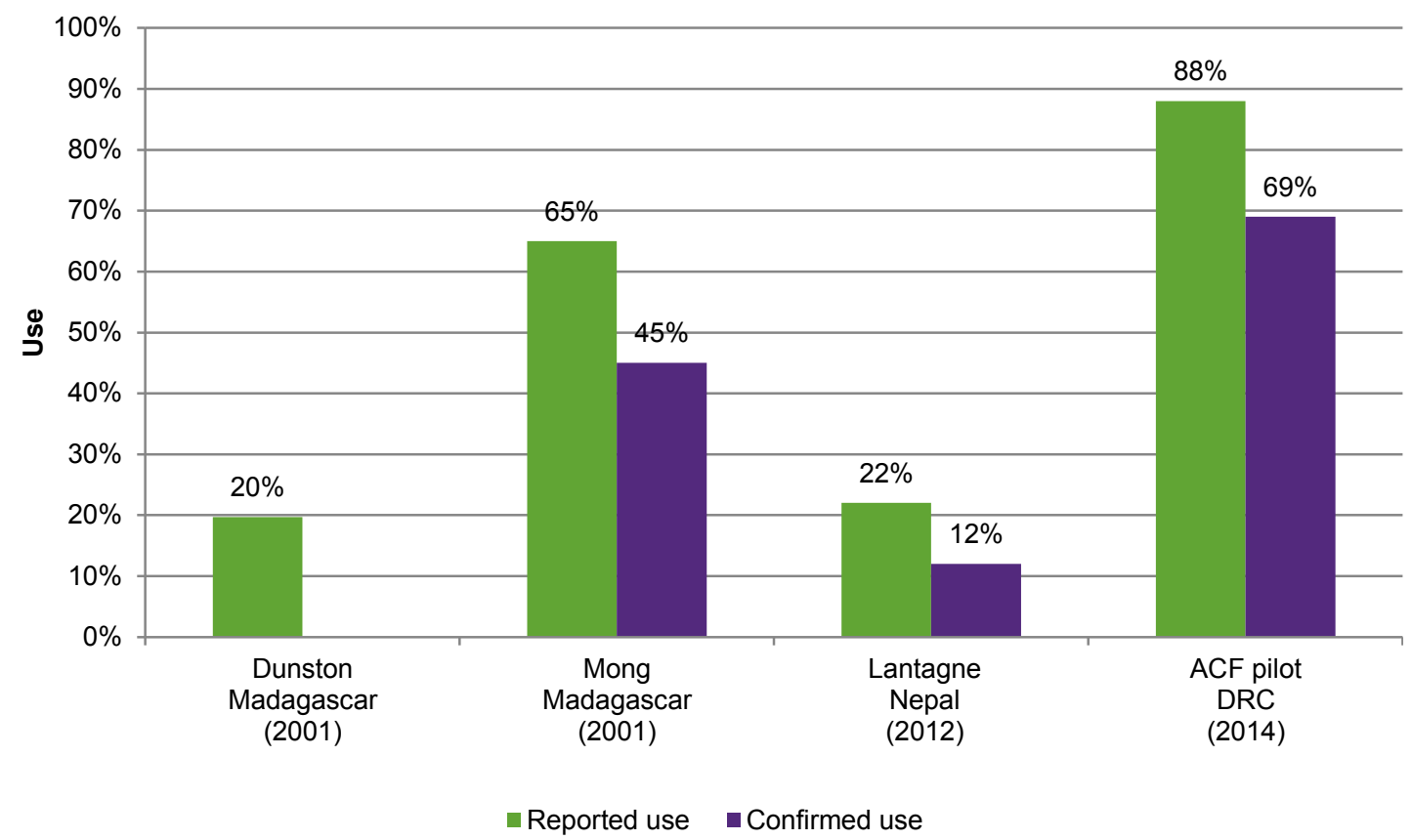

Some of the heterogeneity could be explained by the active promotion of liquid chlorine before the outbreaks in the two studies with higher use rates in the DRC (Tokplo, 2015) and Madagascar (Mong et al., 2001). Cost may explain the low use in Madagascar (Dunston et al., 2001) as the free distribution of the same product had much higher rates in the same area (Mong et al., 2001). Excessive dosing is observed in Madagascar (FCR $>3.5 \mathrm{mg} / \mathrm{L}$ ) (Mong et al., 2001) and taste is only noted as a hindrance to use in Nepal (Lantagne and Clasen, 2012). 
Figure 3.13: Liquid chlorine comparison

\begin{tabular}{|c|c|c|c|c|}
\hline \multirow{2}{*}{$\begin{array}{l}\text { Author } \\
\text { (Year) } \\
\text { Country } \\
\text { Bias }\end{array}$} & \multirow{2}{*}{$\begin{array}{l}\text { Context } \\
\text { approach }\end{array}$} & \multirow[t]{2}{*}{ Evaluation } & \multicolumn{2}{|l|}{ Use outcomes } \\
\hline & & & Reported use & Confirmed use \\
\hline $\begin{array}{l}\text { Mong (2001) } \\
\text { Madagascar } \\
\text { High risk of } \\
\text { bias }\end{array}$ & $\begin{array}{l}\text { Cholera outbreak and cyclone - } \\
\text { Peri-urban } \\
\text { Liquid chlorine and } 5 \text { gallon flexible } \\
\text { jerry can distributed to } 11,700 \mathrm{HH} \\
\text { with some education about use. } \\
\text { Distribution in area with programme } \\
\text { before emergency }\end{array}$ & $\begin{array}{l}\text { Cross-sectional } \\
123 \mathrm{HH}\end{array}$ & $\begin{array}{l}65 \% \text { of } \mathrm{HH} \\
\text { reported use }\end{array}$ & $\begin{array}{l}45 \% \text { of } \mathrm{HH} \\
\text { confirmed use } \\
(\mathrm{FCR} \geq 0.2 \mathrm{mg} / \mathrm{L})\end{array}$ \\
\hline $\begin{array}{l}\text { Lantagne } \\
(2012) \\
\text { Nepal } \\
\text { Low risk of } \\
\text { bias }\end{array}$ & $\begin{array}{l}\text { Cholera outbreak - Extreme rural } \\
\text { Local NGOs using pre-positioned } \\
\text { hygiene kits. } 1,565 \mathrm{HH} \text { received } \\
\text { liquid chlorine (WaterGuard } \circledast \text {, } \\
\text { Piyush } \circledast) \text { but also Aquatabs } ₫ \text { with } \\
\text { hygiene promotion }\end{array}$ & $\begin{array}{l}\text { Cross-sectional } \\
400 \mathrm{HH}\end{array}$ & $\begin{array}{l}22.2 \% \text { reported } \\
\text { use }(2 \text { products: } \\
\text { WaterGuard } \AA \\
6.3 \% ; \text { Piyush } \AA \\
15.8 \%)\end{array}$ & $\begin{array}{l}11.8 \% \text { of } \mathrm{HH} \\
\text { confirmed use } \\
\text { ( } 2 \text { products: } \\
\text { WaterGuard® } \\
3.5 \% \text {; Piyush } \AA \\
8.3 \% \text { ) (FCR } \\
\geq 0.2 \mathrm{mg} / \mathrm{L})\end{array}$ \\
\hline $\begin{array}{l}\text { Dunston } \\
\text { (2001) } \\
\text { Madagascar } \\
\text { High risk of } \\
\text { bias }\end{array}$ & $\begin{array}{l}\text { Cholera outbreak - Urban } \\
\text { Liquid chlorine marketed to } \\
\text { community. Jerry cans available but } \\
\text { not distributed }\end{array}$ & $\begin{array}{l}\text { Cross-sectional } \\
375 \mathrm{HH}\end{array}$ & $\begin{array}{l}19.7 \% \text { of } \mathrm{HH} \\
\text { reported use }\end{array}$ & $\begin{array}{l}\text { No confirmed } \\
\text { use measured }\end{array}$ \\
\hline $\begin{array}{l}\text { ACF (2014) } \\
\text { DRC } \\
\text { High risk of } \\
\text { bias }\end{array}$ & $\begin{array}{l}\text { Endemic cholera - Large } \\
\text { geographic area } \\
\text { Distribution and promotion of liquid } \\
\text { chlorine with vouchers to } 834 \mathrm{HH}\end{array}$ & $\begin{array}{l}\text { Cross-sectional } \\
32 \mathrm{HH}\end{array}$ & $\begin{array}{l}88 \% \text { of } \mathrm{HH} \\
\text { redeemed } \\
\text { voucher (proxy } \\
\text { for use) }\end{array}$ & $\begin{array}{l}69 \% \text { of } \mathrm{HH} \\
\text { confirmed use }\end{array}$ \\
\hline
\end{tabular}

Liquid chlorine is more often linked to long-term development approaches, including promotion (compared with distribution), cost-recovery, social marketing (Dunston et al., 2001), local production (Date et al., 2013) and vouchers (ACF, 2014b). These programme types were all used in liquid chlorine programming, and not described in other interventions. Liquid chlorine was also more regularly used in endemic situations, as areas with endemic or repeated outbreaks are responded to like a development project, occasionally scaling up ongoing interventions.

\section{Liquid chlorine summary}

Liquid chlorine interventions include programmes that promote, distribute, market and redeem vouchers for chlorine solutions. Previous exposure to liquid chlorine in development settings before an outbreak and products distributed at no cost could explain some of the heterogeneity in use, although three of the four studies are high bias. Links to development programming may have contributed to relatively higher use of liquid chlorine than chlorine tablets, which were predominantly distributed in NFI kits (Figure 3.14).

Figure 3.14: Liquid chlorine summary

\begin{tabular}{|l|l|l|l|}
\hline Outcomes & $\begin{array}{l}\text { Number of } \\
\text { studies }\end{array}$ & $\begin{array}{l}\text { Quality of } \\
\text { evidence }\end{array}$ & Summary \\
\hline Health & - & - & - \\
\hline Use & 4 & Low & $\begin{array}{l}\text { Reported use ranged between } 20-88 \% \\
\text { Confirmed use ranged between 12-69\% }\end{array}$ \\
\hline $\begin{array}{l}\text { Barriers and } \\
\text { facilitators }\end{array}$ & 4 & Low & $\begin{array}{l}\text { Exposure to liquid chlorine in non-emergency setting } \\
\text { (familiarity), free distribution, flexibility of intervention } \\
\text { programming }\end{array}$ \\
\hline
\end{tabular}




\section{Combination flocculant/disinfectants}

Combination flocculant/disinfectants, such as P\&G Purifier of Water (formally PUR® and referred to as 'PUR' for this report), are well suited to treat turbid water. To use the sachet, users add the contents to $10 \mathrm{~L}$ of water, stir for five minutes, wait five minutes for the solids to settle, filter the water through a cloth into a second bucket and wait 20 minutes before drinking.

PUR is evaluated in three evaluations, with intermediate outcomes and health impact evaluated. Reported use from two studies ranges between 6 and 78 percent, while confirmed use ranges between 4 and 95 percent. Only one evaluation measured both reported and confirmed use, which were 6 percent and 4 percent respectively (Lantagne and Clasen 2012) (Figure 3.15).

Household knowledge is a factor that may explain some of the variability in use and is commented on in all three studies. High use is attributed to high knowledge of correct use of PUR in South Sudan, as 78 percent of households could demonstrate all the steps required to use PUR. It is noted that while $>90$ percent had confirmed use, PUR use could not be separated from Aquatab® use as both were distributed in the same hygiene kit (ACF 2014a). High use rates (95\%) are also reported from an RCT in Liberia where households were also provided all materials necessary to use PUR at no cost, received extensive training and were visited weekly. High use is also attributed to beneficiaries acknowledging improved water quality, taste and health. However, in a study in Kenya, PUR was distributed through an NFI distribution with minimal promotion. Only 2.3 percent of households could describe the five steps necessary for PUR, translating to similarly low reported use of 5.9 percent, confirmed use of 3.7 percent and effective use of 2.3 percent (Lantagne and Clasen 2012).

Health impact is reported in one evaluation (with high use, in Liberia) where PUR reduced diarrhoea incidence by 67 percent (adjusted RR 0.33; 95\% Cl 0.30-0.37) and diarrhoea prevalence by 77 percent (adjusted RR 0.23; 95\% Cl 0.21-0.25) (Doocy and Burnham 2006).

\section{Figure 3.15: PUR comparison}

\begin{tabular}{|c|c|c|c|c|}
\hline \multirow{2}{*}{$\begin{array}{l}\text { Author (Year) } \\
\text { Country } \\
\text { Bias }\end{array}$} & \multirow{2}{*}{$\begin{array}{l}\text { Context } \\
\text { Approach }\end{array}$} & \multirow[t]{2}{*}{ Evaluation } & \multicolumn{2}{|l|}{ Use outcomes } \\
\hline & & & Reported use & Confirmed use \\
\hline $\begin{array}{l}\text { Doocy }(2006) \\
\text { Liberia } \\
\text { Low risk of } \\
\text { bias }\end{array}$ & $\begin{array}{l}\text { Cholera outbreak - IDP camp } \\
\text { PUR with all necessary equipment } \\
\text { compared with distribution of } 10 \mathrm{~L} \\
\text { buckets only }\end{array}$ & $\begin{array}{l}\text { RCT } \\
200 \mathrm{HH} \text { in } \\
\text { intervention } \\
\text { and } 200 \mathrm{HH} \\
\text { in control } \\
\text { group. }\end{array}$ & Not measured & $\begin{array}{l}95 \% \text { of } \mathrm{HH} \\
\text { confirmed use } \\
(\mathrm{FCR}>0 \mathrm{mg} / \mathrm{L})\end{array}$ \\
\hline $\begin{array}{l}\text { Lantagne } \\
(2012) \\
\text { Kenya } \\
\text { Low risk of } \\
\text { bias }\end{array}$ & $\begin{array}{l}\text { Cholera outbreak - Extreme rural } \\
\text { Pre-positioned stock. Distribution of } \\
\text { Aquatabs } \AA \text { and PUR } ® \text { Purifier of } \\
\text { Water in an NFI kit to } 5,592 \mathrm{HH}\end{array}$ & $\begin{array}{l}\text { Cross- } \\
\text { sectional } \\
409 \mathrm{HH}\end{array}$ & $\begin{array}{l}5.9 \% \text { of } \mathrm{HH} \\
\text { reported use }\end{array}$ & $\begin{array}{l}3.7 \% \text { of } \mathrm{HH} \\
\text { confirmed use } \\
\text { (FCR } \geq 0.2 \mathrm{mg} / \mathrm{L} \text { ) } \\
\text { (Effective use: } \\
2.3 \%)\end{array}$ \\
\hline $\begin{array}{l}\text { ACF (2014) } \\
\text { South Sudan } \\
\text { High risk of } \\
\text { bias }\end{array}$ & $\begin{array}{l}\text { Cholera outbreak - Urban/peri-urban } \\
\text { Aquatabs® distributed in NFI kits to } \\
7,348 \mathrm{HH} \text {. Kit also included: bucket, } \\
\text { PUR® Purifier of Water packets and } \\
\text { filter cloth }\end{array}$ & $\begin{array}{l}\text { Cross- } \\
\text { sectional } \\
351 \mathrm{HH}\end{array}$ & $\begin{array}{l}78 \% \text { of } \mathrm{HH} \\
\text { could } \\
\text { demonstrate } \\
\text { correct use of } \\
\text { PUR }\end{array}$ & $\begin{array}{l}\text { Aquatabs } \\
\text { and/or PUR, } \\
>90 \% \text { of } \mathrm{HH} \\
\text { had FCR (range } \\
83-100 \% \text { ) }\end{array}$ \\
\hline
\end{tabular}

\section{Flocculant/disinfectant summary}

High rates of use correspond with significant diarrheal disease reduction in one low risk intervention. The wide range of use is attributed to the availability and amount of hygiene promotion given to beneficiaries; this is consistent across all interventions (Figure 3.16). 
Figure 3.16: PUR summary

\begin{tabular}{|l|l|l|l|}
\hline Outcomes & $\begin{array}{l}\text { Number } \\
\text { of studies }\end{array}$ & $\begin{array}{l}\text { Quality of } \\
\text { evidence }\end{array}$ & Summary \\
\hline Health & 1 & Low & $\begin{array}{l}67 \% \text { reduced diarrhea incidence and } 77 \% \text { reduced diarrhea } \\
\text { prevalence }\end{array}$ \\
\hline Use & 3 & Low & $\begin{array}{l}\text { Reported use ranged between } 6-78 \%, \mathrm{n}=2 \\
\text { Confirmed use ranged between 4-95\%, } \mathrm{n}=2\end{array}$ \\
\hline $\begin{array}{l}\text { Barriers and } \\
\text { facilitators }\end{array}$ & 3 & Low & Knowledge (promotion) influenced use, improved the taste \\
\hline
\end{tabular}

\section{HWT - other products}

Fewer non-chlorine HWT interventions were identified in the review. Studies documenting filtration, solar disinfection, safe storage and boiling HWT interventions are described in the following sections.

\section{Filtration}

HWT filter types include simple screens, ceramic, sand and hollow-fibre filters. All these filters are generally effective at removing protozoa and bacteria, and some hollow-fibre filters can also remove viruses.

In a large study of $>40,000$ people in an endemic cholera area in Bangladesh, two simple filters (a small nylon screen of $150 \mu \mathrm{m}$ mesh size and a folded piece of sari cloth) were used with intervention group participants and compared with a control group (Colwell et al., 2003). Hospital-recorded cholera morbidity was reduced by approximately 40 percent in both the nylon and sari cloth filter groups (nylon filter RR: 0.59; sari cloth RR: 0.52), with more than 90 percent following the filtering instructions. After five years, participants were revisited, and households in the sari cloth group were more likely to report use of some method of water treatment (35\% compared with control at $23 \%$ and nylon group at $26 \%$ ). Sari filter use was also identified to have a protective reduction in morbidity that extended to neighbours of filter users (Huq et al., 2010). Filter use was identified as simple, improved water appearance, was culturally acceptable and led to improved water appearance and taste (Huq et al., 2010; Colwell et al., 2003).

\section{SODIS}

Solar disinfection (SODIS) uses heat and ultra-violet (UV) radiation from the sun to inactivate bacteria, viruses and protozoa in drinking water. Users place a clear container (i.e. 1.5L plastic bottle) on their roof in the sun for 6-48 hours, depending on amount of direct sunlight, and then drink the water.

SODIS is evaluated in one study in a development context in Kenya that led into an outbreak evaluation when cholera began in the project area (Conroy et al., 2001). The intervention consisted of the distribution of $1.5 \mathrm{~L}$ clear plastic bottles with instructions to give children under 5 years old only SODIS-treated water. SODIS was effective at reducing self-reported cholera rates by 88 percent in these children $(\mathrm{OR}=0.12 ; 95 \% \mathrm{Cl} 0.02-0.65 ; \mathrm{p}=0.014)$.

\section{Safe water storage}

Safe water storage is storing water in a way that reduces the risk of contaminants in the water (i.e. a bucket with a lid and spigot or a narrow-mouthed jerry can rather than an open container where water is accessed with a ladle).

Two evaluations isolating safe water storage were identified in the review; both of these are low bias. The control group in the PUR evaluation in Liberia received jerry cans, and this alone significantly reduced diarrhoea rates by 16 percent from the preceding week $(\mathrm{OR}=0.84,95 \%$ $\mathrm{Cl}$ 0.82-0.86) (Doocy and Burnham, 2006). The second evaluation is from a Malawi refugee camp. 'Improved buckets' with a spout and a permanent partial lid were provided as the intervention in an RCT and compared with regular open buckets as the control (Roberts et al., 
2001). Diarrhoea rates were reduced by 31 percent in children under 5 years and 8 percent overall for the intervention group; however; neither reduction was statistically significant $(p=0.06$ and $p=0.26)$. Improved buckets were effective at reducing bacterial contamination; geometric mean faecal coliforms were reduced by 69 percent in improved buckets compared with regular buckets over six hours after storage. The community preferred the improved buckets to chlorination, as chlorine was associated with a bad taste and smell.

\section{Boiling}

Promotion of boiling is not generally a common outbreak response strategy as it is energy intensive and does not provide residual protection. However, the materials for boiling are often available in the household, and previous education campaigns mean beneficiaries are often aware of boiling. The baseline awareness and reported practice of boiling varies quite widely in the HWT evaluations so far described. For example, boiling was not a promotional activity, but 14 percent of households reported boiling in DRC (Tokplo, 2015) compared with 81 percent in Madagascar (Mong et al., 2001). Only one high risk evaluation included in this review promoted boiling as a response intervention as part of a hygiene campaign for cholera in Guinea-Bissau (Einarsdóttir et al., 2001). After the campaign, 40 percent of households reported boiling water; however, 66 percent reported using lemon to treat water, no households reported consistent use of either method, and no confirmed use evidence was collected.

\section{Summary of other HWT interventions}

Filtration, SODIS, safe storage and boiling HWT interventions were all implemented in nonacute endemic outbreak contexts. The quality of evaluation design is higher than that of chlorine or PUR studies, but is not generalizable for other contexts without multiple studies of the same intervention (Figure 3.17). HWT interventions are consistently reported to be simple, sustainable and accepted by the communities.

Figure 3.17: HWT - other products summary

\begin{tabular}{|l|l|l|l|}
\hline Outcomes & $\begin{array}{l}\text { Number of } \\
\text { studies }\end{array}$ & $\begin{array}{l}\text { Quality of } \\
\text { evidence }\end{array}$ & Summary \\
\hline Health & 4 & Low & $\begin{array}{l}\text { Simple filters, SODIS and safe storage led to significant } \\
\text { reduction in diarrhea in some populations }\end{array}$ \\
\hline Use & 2 & Very low & $\begin{array}{l}\text { Simple filters and boiling had relatively high use, but was limited } \\
\text { to self-reported measures }\end{array}$ \\
\hline $\begin{array}{l}\text { Barriers and } \\
\text { facilitators }\end{array}$ & 3 & Low & $\begin{array}{l}\text { Simple interventions had little to no promotion or instructions but } \\
\text { had relatively high reported use and acceptability }\end{array}$ \\
\hline
\end{tabular}

The goal of sanitation programmes in outbreak response is to break transmission by isolating faeces from the environment, either using output-driven approaches (such as latrine construction) or community-driven approaches.

Output driven - Latrines are designed and built by responders according to a pre-planned number to meet guidelines or based on budget (Sphere Project, 2011). Community involvement in these programmes generally varies from no involvement to volunteering labour/materials, or community members being engaged through a cash-for-work project.

Community driven - Community-driven approaches focus on specific promotion to 'trigger' the community to address its sanitation needs with local materials. Community-Led Total Sanitation (CLTS), Community Approach to Total Sanitation (CATS) and Participatory Hygiene and Sanitation Transformation (PHAST) are all community-driven approaches. Communities are engaged through a facilitator with a specific process and encouraged to build their own latrines from locally available materials. CLTS is a sanitation strategy that focuses on hygiene education and community mobilization to stop open defecation. Similarly, CATS and PHAST use community mobilization, but also provide some material assistance to help build latrines. 
Please note, no evaluations of output-driven sanitation were identified in the review. In some documents and evaluations seen in the review, particularly in community mobilization and WASH package interventions, sanitation is listed only as an activity and not evaluated.

\section{Community-driven sanitation}

Two community-driven sanitation interventions were identified in the review: one CLTS and one PHAST intervention (Figure 3.18).

A CLTS programme in Liberia was implemented for five years before Ebola erupted in Liberia; the CLTS programme continued throughout the outbreak. In a mixed-methods medium bias survey that included 551 household surveys, households in villages that achieved 'open defecation free' through CLTS were 17 times less likely to have cases of Ebola than non-CLTS communities (OR=0.06, $p<0.001)$ (Meyer Capps and Njiru, 2015). Additionally, villages that were triggered by CLTS but had not yet accomplished the open defecation free goal had eight times fewer Ebola cases than communities not in the project.

In a Northern Uganda camp for internally displaced persons (IDP), a PHAST approach including community health clubs was trialled in the midst of a cholera outbreak (Waterkeyn et al., 2005). The evaluation is a high bias field commentary. It is reported that the programme led to more than 8,000 latrines and 6,000 bath shelters constructed in less than four months. Overall, 15,000 people attended weekly hygiene meetings, and group cohesion and peer pressure were noted as mechanisms effective in changing behaviour.

Figure 3.18: Community-driven sanitation comparison

\begin{tabular}{|c|c|c|c|}
\hline $\begin{array}{l}\text { Author (Year) } \\
\text { Country } \\
\text { Bias }\end{array}$ & $\begin{array}{l}\text { Context } \\
\text { Approach }\end{array}$ & Evaluation & Findings \\
\hline $\begin{array}{l}\text { Meyer-Capps (2015) } \\
\text { Liberia } \\
\text { Medium risk of bias }\end{array}$ & $\begin{array}{l}\text { Ebola outbreak - large } \\
\text { geographic area } \\
\text { CLTS project (running for } 5 \\
\text { years - carried on through Ebola } \\
\text { outbreak) in } 6,865 \mathrm{HH}\end{array}$ & $\begin{array}{l}\text { Mixed } \\
\text { methods } \\
\text { Retrospective } \\
\text { control groups } \\
\text { matched } \\
239 \mathrm{HH} \text { in } \\
\text { intervention } \\
\text { and } 312 \mathrm{HH} \text { in } \\
\text { control group } \\
16 \text { focus } \\
\text { groups }\end{array}$ & $\begin{array}{l}\text { HH in CLTS communities } 17 \\
\text { times less likely to have cases } \\
\text { of Ebola than non-CLTS } \\
\text { communities (OR=0.06, } \\
\text { p<0.001) } \\
\text { 'Trust' important feature in } \\
\text { programming } \\
\text { Beneficiaries trusted: } 1 \text { ) health } \\
\text { workers, } 2 \text { ) radio, then } 3 \text { ) NGOs } \\
\text { for sources of information by } \\
\text { both CLTS and non-CLTS } \\
\text { communities }\end{array}$ \\
\hline $\begin{array}{l}\text { Waterkeyn (2005) } \\
\text { Uganda } \\
\text { High risk of bias }\end{array}$ & $\begin{array}{l}\text { Cholera outbreak - IDP camps } \\
\text { Community mobilization through } \\
\text { community health club and } \\
\text { PHAST approaches. Community } \\
\text { trainers, drama presentations, } \\
20 \text { hygiene topics, delivered in } \\
\text { groups, peer pressure to keep } \\
\text { them. Certificate if attended } 20 \\
\text { sessions. Community provided } \\
\text { own materials but would receive } \\
\text { a concrete 'sanplat' (latrine floor) }\end{array}$ & $\begin{array}{l}\text { Field } \\
\text { commentary }\end{array}$ & $\begin{array}{l}\text { Group cohesion and peer } \\
\text { pressure adjusted hygiene } \\
\text { behaviour and improve hygiene } \\
\text { practices } \\
\text { Motivation of }>15,000 \\
\text { beneficiaries: built } 8,500 \\
\text { latrines, } 6,000 \text { bath shelters, } \\
3,400 \text { drying racks and } 1,550 \\
\text { handwashing stations in a } 4- \\
\text { month time frame } \\
\text { Rapid, scalable and cost- } \\
\text { effective }\end{array}$ \\
\hline
\end{tabular}

\section{Sanitation summary}

While output-driven sanitation evaluations are not identified in the review, outcomes of community-driven sanitation interventions were associated with 'trust' and 'cohesion' developed by engaging the communities (this is further described in Section 3.5); albeit the evidence is limited to only two studies, one with high bias. As outbreaks affect entire communities, a community-driven response could be well suited for outbreak response (Figure 3.19). 
Figure 3.19: Community-driven sanitation summary

\begin{tabular}{|l|l|l|l|}
\hline Outcomes & $\begin{array}{l}\text { Number of } \\
\text { studies }\end{array}$ & $\begin{array}{l}\text { Quality of } \\
\text { evidence }\end{array}$ & Summary \\
\hline Health & 1 & Low & $\begin{array}{l}\text { Ebola rates 17 times less in open-defecation-free } \\
\text { communities than in communities with no CLTS intervention }\end{array}$ \\
\hline Use & - & - & - \\
\hline $\begin{array}{l}\text { Barriers and } \\
\text { facilitators }\end{array}$ & 2 & Low & $\begin{array}{l}\text { Trust, cohesion and peer-pressure were positive facilitators } \\
\text { for community-driven intervention }\end{array}$ \\
\hline
\end{tabular}

\section{$3.5 \quad$ HYGIENE}

In the following sections, hygiene interventions are sub-categorized as hygiene promotion (including hygiene education and social mobilization), distribution of hygiene kits and environmental hygiene (jerry can disinfection, household disinfection and environmental clean-up).

\section{Hygiene promotion}

Hygiene promotion is the sharing of personal and environmental hygiene-related information to educate emergency-affected populations with the goal of reinforcing or changing behaviour. In an outbreak context, hygiene promotion must provide accurate information, adapt to changing conditions and appropriately address concerns and fears of the community. Hygiene promotion is separated into two approaches: giving hygiene education messages and facilitating social mobilization.

\section{Hygiene education}

Hygiene education is the delivery of hygiene messages by responders to outbreak-affected populations to improve knowledge and encourage practices (i.e. instructions on using HWT products; messages about handwashing with soap). Eight documents were identified in the review that evaluate hygiene education with preferred message delivery and health impacts (Figure 3.20).

\section{Figure 3.20: Hygiene education comparison}

\begin{tabular}{|c|c|c|c|}
\hline $\begin{array}{l}\text { Author (Year) } \\
\text { Country } \\
\text { Bias }\end{array}$ & $\begin{array}{l}\text { Context } \\
\text { Approach }\end{array}$ & Evaluation & Findings \\
\hline $\begin{array}{l}\text { Einarsóbttir } \\
\text { (2001) } \\
\text { Guinea-Bissau } \\
\text { High risk of } \\
\text { bias }\end{array}$ & $\begin{array}{l}\text { Cholera outbreak - Rural } \\
\text { Hygiene promotion to support } \\
\text { treating water (and other hygiene } \\
\text { practices). Radio, TV, health staff, } \\
\text { poster, word-of-mouth, song, } \\
\text { theatre group; } 53 \mathrm{HH} \text { surveyed }\end{array}$ & $\begin{array}{l}\text { Cross-sectional } \\
53 \mathrm{HH}\end{array}$ & $\begin{array}{l}\text { Received communication: } 94 \% \\
\text { report hearing at least one } \\
\text { message: } 1 \text { ) Radio (45\%); } 2) \\
\text { Word of mouth ( } 41 \% \text {, despite no } \\
\text { door-to-door messaging); } 3 \text { ) } \\
\text { poster (24\%) } \\
\text { Barriers: Language issue with } \\
\text { radio messages; posters not } \\
\text { effective as many people were } \\
\text { illiterate; transmission routes not } \\
\text { well described. Many thought } \\
\text { transmission was through the air; } \\
\text { spirit sacrifices done frequently }\end{array}$ \\
\hline $\begin{array}{l}\text { Date (2013) } \\
\text { Kenya } \\
\text { High risk of } \\
\text { bias }\end{array}$ & $\begin{array}{l}\text { Cholera outbreak - Rural } \\
\text { Evaluation of promotional activities } \\
\text { with distribution of HWT and } \\
\text { hygiene kits (not described); } 723 \\
\text { HH surveyed }\end{array}$ & $\begin{array}{l}\text { Cross-sectional } \\
\text { with comparison } \\
\text { group } \\
358 \text { intervention } \\
\mathrm{HH} \text { and } 365 \\
\text { control HH }\end{array}$ & $\begin{array}{l}\text { Social contacts (friends, family } \\
\text { and neighbours) primary } \\
\text { information source of HH aware } \\
\text { of the outbreak }\end{array}$ \\
\hline
\end{tabular}




\begin{tabular}{|c|c|c|c|}
\hline $\begin{array}{l}\text { Author (Year) } \\
\text { Country } \\
\text { Bias }\end{array}$ & $\begin{array}{l}\text { Context } \\
\text { Approach }\end{array}$ & Evaluation & Findings \\
\hline $\begin{array}{l}\text { Contzen- } \\
\text { Mosler (2013) } \\
\text { Haiti } \\
\text { Medium risk of } \\
\text { bias }\end{array}$ & $\begin{array}{l}\text { Cholera outbreak - Urban } \\
\text { Evaluation of communication } \\
\text { strategies after cholera intervention } \\
\text { (not specific to one intervention) }\end{array}$ & $\begin{array}{l}\text { Cross-sectional } \\
811 \mathrm{HH} \text { survey }\end{array}$ & $\begin{array}{l}\text { For both faeces and food-related } \\
\text { handwashing, the most effective } \\
\text { modes of hygiene were: material } \\
\text { distributions with demonstrations } \\
\text { and radio spots. Spontaneous/ } \\
\text { unplanned promotions by friends } \\
\text { and neighbours also influential } \\
\text { Focus groups, hygiene days and } \\
\text { stickers/posters/paintings were } \\
\text { rated as less likeable, less } \\
\text { convincing and less trustworthy } \\
\text { than other methods }\end{array}$ \\
\hline $\begin{array}{l}\text { Williams } \\
(2015) \\
\text { Haiti } \\
\text { Medium risk of } \\
\text { bias }\end{array}$ & $\begin{array}{l}\text { Cholera outbreak - Large } \\
\text { geographic area } \\
\text { Evaluation of communication } \\
\text { strategies after cholera } \\
\text { interventions (not specific to one } \\
\text { intervention) }\end{array}$ & $\begin{array}{l}\text { Qualitative } \\
18 \text { focus groups } \\
\text { assess regional } \\
\text { preferences }\end{array}$ & $\begin{array}{l}\text { Community health worker and } \\
\text { megaphone going house to } \\
\text { house were the best way to reach } \\
\text { the communities } \\
\text { Most 'trusted' vender of HWT } \\
\text { products was pharmacies } \\
\text { Self-reported increase in } \\
\text { handwashing as a result of } \\
\text { messaging } \\
\text { Self-perceived reduction in } \\
\text { diarrhea reported from community } \\
\text { in focus groups }\end{array}$ \\
\hline $\begin{array}{l}\text { Wall (2011) } \\
\text { Haiti } \\
\text { Medium risk of } \\
\text { bias }\end{array}$ & $\begin{array}{l}\text { Cholera outbreak - Large } \\
\text { geographic area } \\
\text { Evaluation of communication after } \\
\text { cholera and earthquake (not } \\
\text { specific to one intervention) }\end{array}$ & $\begin{array}{l}\text { Qualitative } \\
15 \text { focus groups }\end{array}$ & $\begin{array}{l}\text { Multiple channels of } \\
\text { communication to share and } \\
\text { listen, reinforcing and listening in } \\
\text { complementary ways } \\
\text { Cholera treatment centres were } \\
\text { initially rejected by population due } \\
\text { to fears about the origin and } \\
\text { response to the disease } \\
\text { The assessments of overall effect } \\
\text { on communication efforts on } \\
\text { cholera, as 'too many } \\
\text { organizations were involved and } \\
\text { too many techniques used' }\end{array}$ \\
\hline $\begin{array}{l}\text { WHO (no date) } \\
\text { Guidance on } \\
\text { Communication } \\
\text { - Case study } \\
\text { South Africa } \\
\text { High risk of } \\
\text { bias }\end{array}$ & $\begin{array}{l}\text { Cholera outbreak - Large } \\
\text { geographic area } \\
\text { Hygiene campaign, messages: } \\
\text { water storage, personal hygiene, } \\
\text { safe refuse disposal, food handling, } \\
\text { use of HWT } \\
\text { Mode: health workers, schools, } \\
\text { religious leaders; some religious } \\
\text { services use to recruit volunteers }\end{array}$ & $\begin{array}{l}\text { Field } \\
\text { commentary }\end{array}$ & $\begin{array}{l}\text { Red Cross (working in specific } \\
\text { areas) reported (unverified) a } \\
\text { sharp decline in mortality rates } \\
\text { following education programme }\end{array}$ \\
\hline $\begin{array}{l}\text { WHO (no date) } \\
\text { Zimbabwe } \\
\text { High risk of } \\
\text { bias }\end{array}$ & $\begin{array}{l}\text { Cholera outbreak - Large } \\
\text { geographic area } \\
\text { Messages: Cholera prevention, } \\
\text { control, food preparation, } \\
\text { handwashing, use of HWT } \\
\text { (tablets/sachets) } \\
\text { Mode: T-shirts and drama } \\
\text { presentations used, } 310,000 \text { flyers, } \\
14,000 \text { posters in three languages } \\
\text { distributed to } 250,000 \text { people }\end{array}$ & $\begin{array}{l}\text { Field } \\
\text { commentary }\end{array}$ & $\begin{array}{l}\text { Reported change in behaviour - } \\
\text { not attending funerals, reducing } \\
\text { physical contact (hugs, shaking } \\
\text { hands) } \\
\text { Response built on existing } \\
\text { programming } \\
\text { Unwillingness to drink chlorinated } \\
\text { water } \\
\text { Lack of resources and devaluing } \\
\text { currency }\end{array}$ \\
\hline $\begin{array}{l}\text { ACF - } \\
\text { Matemo } \\
(2014) \\
\text { Kenya } \\
\text { High risk of } \\
\text { bias }\end{array}$ & $\begin{array}{l}\text { Cholera and hepatitis E outbreak - } \\
\text { Refugee camp } \\
\text { Hydrogen sulfide test used as part } \\
\text { of hygiene promotion as a visual } \\
\text { aid to assist hygiene messaging as } \\
\text { well as test water samples }\end{array}$ & $\begin{array}{l}\text { Field } \\
\text { commentary }\end{array}$ & $\begin{array}{l}\text { Communication improved. } \\
\text { Feedback to communities with } \\
\text { tangible explanations that 'clear } \\
\text { doesn't mean safe' }\end{array}$ \\
\hline
\end{tabular}


Hygiene message delivery is assessed in five evaluations through quantitative and qualitative evaluation methods. The studies' biases are medium to high in all studies, but findings are consistent across multiple countries and contexts. Common factors that were evaluated are:

- person sharing the message (i.e. community health worker, NGO, friend, neighbour, family member, local leader)

- how it was shared (i.e. radio, TV, posters/pamphlets, theatrical skits, face to face)

- location (i.e. home, school, place of worship, community).

Some form of face-to-face communication was highlighted as positive by beneficiaries in all five evaluations (Williams et al., 2015; Matemo, 2014; Contzen and Mosler, 2013; Date et al., 2013; Einarsdóttir et al., 2001; Wall and Chéry, 2011). Additionally, material demonstrations (i.e. instruction on HWT), visits by community health workers and conversations with friends and family were consistently highlighted as positive. Short radio 'spots' or radio communication were also consistently preferred or trusted by communities.

Delivering simple, clear messages was a notable challenge in four studies. Different and conflicting messages undermined the response in the Haiti cholera and Liberia Ebola response (Wall and Chéry, 2011; Meyer Capps and Njiru, 2015). There were also doubts if hearing a message on the radio translates to a realistic understanding of the local situation (Wall and Chéry, 2011). Difficulties with language, dialect differences (Einarsdóttir et al., 2001) and errors in printed information were additional challenges noted (Neseni and Guzha, 2009).

Health impact is qualitatively described as an observed sharp decline in morbidity following the education programme in South Africa and a community-perceived reduction in diarrhoea rate in Haiti (WHO, no date; Williams et al., 2015). Differences in behaviour are also noted with an increase in HWT use in Kenya (Date et al., 2013) and reducing physical contact (i.e. hugs, shaking hands) in Zimbabwe during a cholera outbreak (WHO, no date).

\section{Hygiene education summary}

Hygiene education is assessed through a combination of quantitative, qualitative and field commentary approaches. Despite high bias, the same modes of communication (face to face and radio) were consistently found to be preferred (Figure 3.21). Impact on health and use were also reported with weak evaluations.

\section{Figure 3.21: Hygiene education summary}

\begin{tabular}{|l|l|l|l|}
\hline Outcomes & $\begin{array}{l}\text { Number of } \\
\text { studies }\end{array}$ & $\begin{array}{l}\text { Quality of } \\
\text { evidence }\end{array}$ & Summary \\
\hline Health & 2 & Low & $\begin{array}{l}\text { Anecdotal descriptions of disease or disease risk } \\
\text { reductions }\end{array}$ \\
\hline Use & 1 & Very low & Reported use of HWT increased \\
\hline $\begin{array}{l}\text { Barriers and } \\
\text { facilitators }\end{array}$ & 8 & Moderate & $\begin{array}{l}\text { Face-to-face communication and radio are preferred } \\
\text { and trusted by the community }\end{array}$ \\
\hline
\end{tabular}

\section{Social mobilization}

'Social mobilization' is a term to describe strategies for involving or engaging communities in the outbreak response, with responders facilitating communities to address identified risks with local solutions. Six documents in five countries use a social mobilization approach in their outbreak response (Figure 3.22). Risk of bias is high, with two-thirds of the studies being field commentaries. 
Figure 3.22: Social mobilization comparison

\begin{tabular}{|c|c|c|c|}
\hline $\begin{array}{l}\text { Author (Date) } \\
\text { Country } \\
\text { Bias }\end{array}$ & $\begin{array}{l}\text { Context } \\
\text { Approach }\end{array}$ & Evaluation & Findings \\
\hline $\begin{array}{l}\text { Meyer Capps } \\
(2015) \\
\text { Liberia } \\
\text { Medium risk of } \\
\text { bias }\end{array}$ & $\begin{array}{l}\text { Ebola outbreak - Large } \\
\text { geographic area } \\
\text { CLTS }\end{array}$ & $\begin{array}{l}\text { Matched controls. } \\
239 \text { project } \mathrm{HH}: 312 \\
\text { non-project } \mathrm{HH}\end{array}$ & $\begin{array}{l}\text { HH in CLTS communities } 17 \\
\text { times less likely to have cases } \\
\text { of Ebola than non-CLTS } \\
\text { communities (OR=0.06, } \\
\text { p<0.001) } \\
\text { Beneficiaries trusted: } 1 \text { ) health } \\
\text { workers, } 2 \text { ) radio, then } 3 \text { ) NGOs } \\
\text { as sources of information }\end{array}$ \\
\hline $\begin{array}{l}\text { Waterkeyn (2005) } \\
\text { Uganda } \\
\text { High risk of bias }\end{array}$ & $\begin{array}{l}\text { Cholera and hepatitis E } \\
\text { outbreak - IDP camps } \\
\text { Community health clubs } \\
\text { and PHAST }\end{array}$ & Field commentary & $\begin{array}{l}\text { Group cohesion and peer } \\
\text { pressure adjusted hygiene } \\
\text { behaviour and improve hygiene } \\
\text { practices } \\
\text { Motivation of }>15,000 \\
\text { beneficiaries built } 8,500 \text { latrines, } \\
6,000 \text { bath shelters, } 3,400 \\
\text { drying racks and } 1,550 \\
\text { handwashing stations in a four- } \\
\text { month time frame }\end{array}$ \\
\hline $\begin{array}{l}\text { Wall (2011) } \\
\text { Haiti } \\
\text { Medium risk of } \\
\text { bias }\end{array}$ & $\begin{array}{l}\text { Cholera outbreak - Large } \\
\text { geographic area } \\
\text { Various communication } \\
\text { strategies from many } \\
\text { organizations }\end{array}$ & $\begin{array}{l}\text { Qualitative } \\
15 \text { focus group } \\
\text { discussions }\end{array}$ & $\begin{array}{l}\text { Maintaining relationships and } \\
\text { sharing difficult information, } \\
\text { open channels of } \\
\text { communication }\end{array}$ \\
\hline $\begin{array}{l}\text { Institute of Water } \\
\text { and Sanitation } \\
\text { Development - } \\
\text { Neseni (2009) } \\
\text { Zimbabwe } \\
\text { High risk of bias }\end{array}$ & $\begin{array}{l}\text { Cholera outbreak - Large } \\
\text { geographic area } \\
\text { Social mobilization, WASH } \\
\text { activities }\end{array}$ & Field commentary & $\begin{array}{l}\text { Social mobilization considered } \\
\text { most impactful to reduce } \\
\text { disease transmission }\end{array}$ \\
\hline $\begin{array}{l}\text { International } \\
\text { Federation of Red } \\
\text { Cross and Red } \\
\text { Crescent } \\
\text { Societies - Rees- } \\
\text { Gildea (2013) } \\
\text { Sierra Leone } \\
\text { High risk of bias }\end{array}$ & $\begin{array}{l}\text { Cholera outbreak - Large } \\
\text { geographic area } \\
\text { Social mobilization } \\
\text { Sensitization programme } \\
\text { to } 350,000 \text { people }\end{array}$ & Field commentary & $\begin{array}{l}\text { Decrease in case fatality rate } \\
\text { assessed to be more influenced } \\
\text { by social mobilization than case } \\
\text { management }\end{array}$ \\
\hline $\begin{array}{l}\text { ACF (2015) } \\
\text { Sierra Leone } \\
\text { High risk of bias }\end{array}$ & $\begin{array}{l}\text { Ebola outbreak - Peri- } \\
\text { urban } \\
\text { Community-Led Ebola } \\
\text { Management and } \\
\text { Eradication (CLEME), as } \\
\text { modified CLTS approach } \\
\text { with community-driven } \\
\text { action. ACF also involved } \\
\text { in other aspects of the } \\
\text { response }\end{array}$ & Field commentary & $\begin{array}{l}\text { Social mobilization better than } \\
\text { case management } \\
\text { - Community ownership and trust } \\
\text { - } 80 \% \text { of communities planned } \\
\text { isolation rooms; 'tippy tap' } \\
\text { handwashing widely promoted }\end{array}$ \\
\hline
\end{tabular}

Through a mixture of research methods that are high and medium risk of bias, community mobilizers were engaged with the community to have a conversation and ask questions. Compared with a purely education campaign that is 'top-down,' designed to deliver or extract information (Contzen and Mosler, 2013), community-mobilization (engagement) approaches were conducive to NGOs: listening to communities, dispelling fears and stigmas and learning how to adapt to the context. For example, a 'dialogue-based' approach by NGOs led to an improved understanding of the community, leading to a better response as viewed by the community (Wall and Chéry, 2011). 
Social mobilization is qualitatively assessed in high risk of bias studies to reduce disease transmission better than disease case management (ACF, 2015; Rees-Gildea, 2013; Neseni and Guzha, 2009). The CLTS programme in Liberia Ebola response (described in Section 3.4) had a strong and significant reduction in disease risk (Meyer Capps and Njiru, 2015).

Stronger community relationships are also described in three of the social mobilization evaluations (Wall and Chéry, 2011; Waterkeyn et al., 2005; ACF, 2015). For example, an NGO piloted a community mobilization project based on CLTS methodology tailored to Ebola management (ACF CLEME). Isolation rooms and handwashing stations were most commonly constructed by the community, but community ownership and trust are also noted as important project results. A combined community health club and PHAST approach was trialled in the midst of a cholera outbreak in Northern Uganda IDP camps with 'group cohesion' as a factor to success (Waterkeyn et al., 2005).

Policy documents (not included in the review) also describe strong support for community engagement. A learning document for haemorrhagic fever outbreaks notes that, 'community engagement and social mobilization are key aspects of reducing transmission rates' (Oxfam, 2014).

\section{Social mobilization summary}

Hygiene education and social mobilization are not mutually exclusive, but interventions that use community engagement approaches were consistently supported in outbreak contexts by beneficiaries and NGOs (Figure 3.23). Community empowerment and trust led to reductions in disease risk through adaptable approaches.

\section{Figure 3.23: Social mobilization summary}

\begin{tabular}{|l|l|l|l|}
\hline Outcomes & $\begin{array}{l}\text { Number of } \\
\text { studies }\end{array}$ & $\begin{array}{l}\text { Quality of } \\
\text { evidence }\end{array}$ & Summary \\
\hline Health & 4 & Low & $\begin{array}{l}\text { Anecdotal descriptions of disease impact and significant } \\
\text { quantitative approaches that reduced risk of Ebola } \\
\text { evaluated (Meyer-Capps) }\end{array}$ \\
\hline Use & - & - & - \\
\hline $\begin{array}{l}\text { Barriers and } \\
\text { facilitators }\end{array}$ & 4 & Low & Trust and ownership consistently documented \\
\hline
\end{tabular}

\section{Hygiene kit distribution}

Hygiene kit distributions (e.g. NFIs) are mentioned in 17 evaluations. HWT products, soap and safe water storage containers are most commonly included. The primary goal of most hygiene kit distributions is to deliver HWT products and/or support hygiene activities addressed in other sections of this report. There are two hygiene kit interventions not described in other sections but included in the review (Figure 3.24). 
Figure 3.24: Hygiene kit comparison

\begin{tabular}{|c|c|c|c|}
\hline $\begin{array}{l}\text { Author (Year) } \\
\text { Country } \\
\text { Bias }\end{array}$ & Activities & Evaluation & Findings \\
\hline $\begin{array}{l}\text { UNICEF - } \\
\text { Ruiz Roman } \\
\text { (2009) } \\
\text { Zimbabwe } \\
\text { High risk of } \\
\text { bias }\end{array}$ & $\begin{array}{l}\text { Cholera outbreak - Large } \\
\text { geographic area } \\
\sim 200,000 \mathrm{HH} \text { hygiene kit } \\
\text { distribution from several } \\
\text { organizations; recommended } \\
\text { kit included: One } 20 \mathrm{~L} \text { bucket, } \\
\text { one } 20 \mathrm{~L} \text { bucket with tap, one } \\
\text { bar of soap, } 30 \text { water } \\
\text { purification tablets, three ORS } \\
\text { sachets, and one pack of } \\
\text { information, education and } \\
\text { communication materials }\end{array}$ & $\begin{array}{l}\text { Mixed- } \\
\text { methods } \\
307 \mathrm{HH}, 6 \\
\text { focus group } \\
\text { discussion, } 23 \\
\text { key informant } \\
\text { interviews }\end{array}$ & $\begin{array}{l}87 \% \text { of } \mathrm{HH} \text { reported receiving a } \\
\text { hygiene kit; only } 33 \% \text { reported } \\
\text { receiving all } 5 \text { recommended items } \\
\text { (differences in kits) } \\
59 \% \text { of } \mathrm{HH} \text { requested additional } \\
\text { quantities - mostly from families of } 6 \text { or } \\
\text { more } \\
\text { Soap was reported to be the most used } \\
\text { item (not quantified) }\end{array}$ \\
\hline $\begin{array}{l}\text { CRS - } \\
\text { Pennacchia } \\
(2011) \\
\text { DRC } \\
\text { High risk of } \\
\text { bias }\end{array}$ & $\begin{array}{l}\text { Endemic cholera - Urban and } \\
\text { rural } \\
\mathrm{NFI} \text { fair: US } \$ 70 \text { voucher for } \\
2,184 \text { beneficiaries }(\mathrm{HH})- \\
\text { special NFI market created for } \\
\text { voucher programme } \\
\text { Also WASH activities } \\
\text { described in Figure } 3.28, \\
\text { including } \\
\text { construction/rehabilitation of } \\
\text { water sources and hygiene } \\
\text { stations and hygiene } \\
\text { promotion }\end{array}$ & $\begin{array}{l}\text { Cross- } \\
\text { sectional } \\
332 \mathrm{HH} \\
\text { surveyed for } \\
\text { voucher } \\
\text { impact }\end{array}$ & $\begin{array}{l}\text { Vulnerability score dropped from } 3.2 \text { to } \\
1.6 \text { three months after voucher } \\
\text { programme, } \geq 2.9 \text { is the threshold for } \\
\text { emergency intervention } \\
\text { Voucher - beneficiaries 'empowered' to } \\
\text { choose their own needs } \\
\text { More than US } \$ 150,000 \text { spent in local } \\
\text { markets } \\
\text { Beneficiaries thought prices (via } \\
\text { voucher market) were competitive, } \\
80 \% \text { thought prices were at or below } \\
\text { market } \\
85 \% \text { of vendors said they reduced } \\
\text { prices through negotiation }\end{array}$ \\
\hline
\end{tabular}

Also referencing other documents included in this review, hygiene kits facilitate HWT products, hygiene promotion and are common to outbreak response. Hygiene kits are not often evaluated as standalone interventions, but barriers and facilitators of hygiene kits are described throughout studies included in this review. Interventions were facilitated when supplies were pre-positioned (Simpson et al., 2009; DeGabriele and Musa, 2009; Neseni and Guzha, 2009; Ruiz-Roman, 2009; Lantagne and Clasen, 2012) and when supplies were distributed in a timely manner (Neseni and Guzha, 2009; ACF, 2007). Vouchers were used to offer flexibility and choice to beneficiaries (Pennacchia et al., 2011), whereas standardized kits were barriers to families with different sizes and needs (Gauthier, 2014; Simpson et al., 2009).

\section{Hygiene kit summary}

Hygiene kits are an intervention to equip outbreak affected populations with materials necessary to improve hygiene practices. Most NFI interventions are assessed as HWT interventions, quality of bias is high, but barrier and facilitating factors are consistent. Contents, quantity and timely distribution are important factors (Figure 3.25).

Figure 3.25: Hygiene kit summary

\begin{tabular}{|l|l|l|l|}
\hline Outcomes & $\begin{array}{l}\text { Number } \\
\text { of studies }\end{array}$ & $\begin{array}{l}\text { Quality of } \\
\text { evidence }\end{array}$ & Summary \\
\hline Health & - & - & - \\
\hline Use & - & - & - \\
\hline $\begin{array}{l}\text { Barriers and } \\
\text { facilitators }\end{array}$ & 8 & Low & $\begin{array}{l}\text { Quantity of materials not adequate or adaptable, and } \\
\text { timeliness of delivery are important factors - especially to } \\
\text { enable HWT and hygiene messages pre-positioning }\end{array}$ \\
\hline
\end{tabular}




\section{Environmental hygiene}

Environmental hygiene efforts aim to protect populations by reducing environmental transmission of disease. In outbreak response, environmental hygiene includes:

- jerry can disinfection - cleaning jerry cans with chlorine solution

- household disinfection - sanitizing a home or building that is potentially contaminated with chlorine solution (i.e. an Ebola patient's home)

- environment clean-up - rubbish collection, drainage and landscape improvements that aim to remove contaminated solid and liquid wastes.

Environmental hygiene interventions are discussed in four evaluations included in the review, evaluating jerry can disinfection and household disinfection hygiene kit interventions.

\section{Jerry can disinfection}

Jerry can disinfection is investigated in three evaluations, all in camp settings and all assessed with no beneficiary input (Figure 3.26).

\section{Figure 3.26: Jerry can disinfection comparison}

\begin{tabular}{|c|c|c|c|}
\hline $\begin{array}{l}\text { Author (Year) } \\
\text { Country } \\
\text { Bias }\end{array}$ & $\begin{array}{l}\text { Context } \\
\text { Approach }\end{array}$ & Evaluation & Findings \\
\hline $\begin{array}{l}\text { Steele (2008) } \\
\text { Uganda } \\
\text { High risk of } \\
\text { bias }\end{array}$ & $\begin{array}{l}\text { Endemic cholera - IDP camp } \\
\text { Disinfecting jerry cans with } 3 \% \\
\text { sodium hypochlorite solution } \\
\text { using two different cleaning } \\
\text { methods: } \\
\text { 1) Fill halfway with disinfectant } \\
\text { solution, seal, shake for } 1 \\
\text { minute, decant back into stock } \\
\text { solution; } n=9 \\
\text { 2) Fill with stock solution, let sit } \\
\text { for } 1-5 \text { minutes, decant back } \\
\text { into stock solution; } n=4\end{array}$ & $\begin{array}{l}\text { Quantitative } \\
\text { Jerry cans from } 13 \\
\mathrm{HH} \text { borrowed then } \\
\text { revisited } 3-5 \text { days } \\
\text { after cleaning }\end{array}$ & $\begin{array}{l}\text { Data indicates that both methods } \\
\text { are equally effective (low sample } \\
\text { size); Method } 1 \text { had more } \\
\text { consistent lower coliform counts } \\
\text { than Method } 2 \\
\text { Overall: } 92 \%(11 / 12) \text { had } \\
\text { reduced Escherichia coli bacteria } \\
\text { (E. coli) after cleaning; } 75 \% \\
\text { (9/12) had }<5 \text { E. coli after } \\
\text { cleaning; } 42 \%(5 / 12) \text { had }<1 \\
\text { E. coli after cleaning } \\
\text { One-time disinfection did not } \\
\text { affect recontamination } 3-5 \text { days } \\
\text { later }\end{array}$ \\
\hline $\begin{array}{l}\text { Walden (2005) } \\
\text { Sudan } \\
\text { High risk of } \\
\text { bias }\end{array}$ & $\begin{array}{l}\text { Shigellosis - IDP camp } \\
\text { Disinfecting jerry cans with } 5 \% \\
\text { chlorine solution: } \\
100-150 \mathrm{~mL} \text { added to each } \\
\text { bucket with stones (as } \\
\text { abrasives), sealed, shaken } \\
\text { vigorously, dumped, refilled } \\
\text { with } 1 \% \text { chlorine solution; } 15- \\
20 \text { minutes/container }\end{array}$ & $\begin{array}{l}\text { Field commentary } \\
\text { Case report }\end{array}$ & $\begin{array}{l}\text { On average, the FCR remaining } \\
\text { in the containers was } 0.2 \mathrm{mg} / \mathrm{L} \text {, } \\
\mathrm{n}=172 \\
\text { Number of watery and bloody } \\
\text { cases of diarrhea continued to } \\
\text { decline after the disinfection } \\
\text { One week later, observations } \\
\text { were that people were keeping } \\
\text { containers clean }\end{array}$ \\
\hline $\begin{array}{l}\text { Roberts (2001) } \\
\text { Malawi } \\
\text { High risk of } \\
\text { bias }\end{array}$ & $\begin{array}{l}\text { Cholera outbreaks - refugee } \\
\text { camp } \\
\text { Buckets were chlorinated with } \\
2.5 \mathrm{mg} / \mathrm{L} \text { solution } 8 \text { times over } \\
2 \text { months }\end{array}$ & $\begin{array}{l}\text { Cross-sectional } \\
24 \text { buckets }\end{array}$ & $\begin{array}{l}\text { Faecal coliform virtually } \\
\text { eliminated for } 4 \text { hours, but } \\
\text { increased after } 6 \text { hours } \\
\text { Stock solution concentrations } \\
\text { were considerably lower than } \\
\text { intended on several occasions, } \\
\text { leading to inadequate } \\
\text { chlorination }\end{array}$ \\
\hline
\end{tabular}

All three jerry can cleaning methods were assessed to reduce disease risk with very weak evaluation methods. Chlorine concentration degradation is noted in all three documents (Steele et al., 2008; Walden et al., 2005; Roberts et al., 2001), although the chlorine residual reported in Roberts et al (2001) is not a suitable chlorine concentration for cleaning inanimate objects; however, the evaluation focused on HWT, not cleaning. One-time disinfection did not have a long-term impact on re-contamination. 


\section{Household disinfection}

Household spraying is described as an activity in five documents (Neseni and Guzha, 2009; Gauthier, 2014; Grayel 2014, 2011, 2012) but is not assessed. A known outbreak activity, household or community spraying has several drawbacks, as described in Box, 'Household spraying with chlorine solution' below.

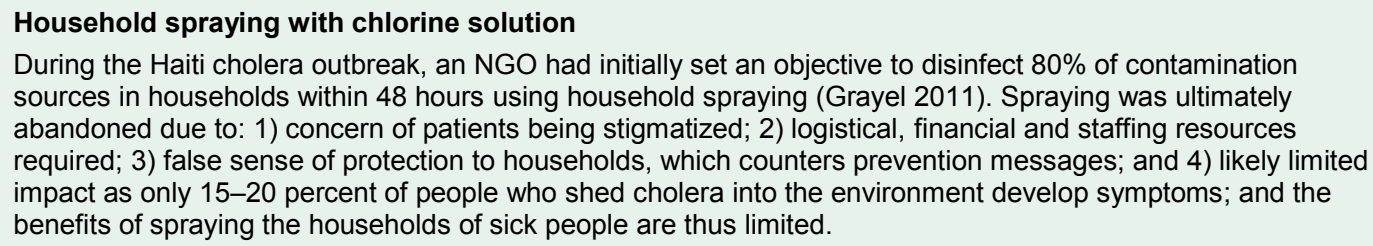
sources in households within 48 hours using household spraying (Grayel 2011). Spraying was ultimately abandoned due to: 1) concern of patients being stigmatized; 2) logistical, financial and staffing resources required; 3 ) false sense of protection to households, which counters prevention messages; and 4) likely limited impact as only 15-20 percent of people who shed cholera into the environment develop symptoms; and the benefits of spraying the households of sick people are thus limited.

Documents not included in the review also describe the limitations of household spraying. In the Ebola response in West Africa, household spraying did not include bedding and other possible routes of transmission, thus spraying was 'incomplete' and likely ineffective (Nielsen et al., 2015). The UNICEF Cholera Toolkit also suggests that one-time household spraying is often carried out too late, is resource intensive, has no evidence of effectiveness and can stigmatize the household (UNICEF, 2013); however, it is recommended that families should thoroughly clean the house with soap and chlorine solution.

As an alternative to household spraying by sending disinfection teams to patients' households, Médecins Sans Frontières provided cholera patients with a self-disinfection kit for the household in the cholera outbreak in Haiti. After a 30-40 minute group hygiene session, kits were given to the patient or caretaker, including: $0.5-1 \mathrm{~kg}$ of soap, a $14 \mathrm{~L}$ bucket, a $10 \mathrm{~L}$ jerry can, $3.8 \mathrm{~L}$ of bleach, a cloth, a scrubbing brush and an instruction book (Gartley et al., 2013). In this high bias evaluation, self-reported use of the disinfection kits is 98 percent, with 94 percent of recipients reporting the instructions were clear and simple; however, no verification on correct use or reduced transmission was reported. A significant increase in use $(p<0.05)$ is reported when the hygiene session explained how to use the contents together and encouraged sharing with friends and family.

\section{Environment clean-up}

No evaluation on improving local environment conditions is identified in the review, although several organizations report activities or results such as 'improved garbage practices' (Dinku, 2011), construction of solid waste areas and drainage improvements (Pennacchia et al., 2011), and decongestion and rehabilitation of sewer pipes (Neseni and Guzha, 2009).

\section{Environmental hygiene summary}

Jerry can disinfection interventions are assessed with very weak research designs, but consistent results (Figure 3.27). Household disinfection and environment clean-up are common emergency response activities, but no evaluations of these interventions is identified in the review except for one evaluation of household disinfection kit distribution with only self-reported outcomes where families cleaned their homes themselves.

Figure 3.27: Environmental hygiene summary

\begin{tabular}{|l|l|l|l|}
\hline Outcomes & $\begin{array}{l}\text { Number of } \\
\text { studies }\end{array}$ & $\begin{array}{l}\text { Quality of } \\
\text { evidence }\end{array}$ & Summary \\
\hline Health & 4 & Very low & $\begin{array}{l}\text { Very weak evaluation methods consistently reportedly } \\
\text { reduced disease transmission from chlorine disinfection }\end{array}$ \\
\hline Use & 1 & Very low & Use of distributed hygiene kit is high bias with high use rates \\
\hline $\begin{array}{l}\text { Barriers and } \\
\text { facilitators }\end{array}$ & 3 & Low & $\begin{array}{l}\text { Chlorine solution needs constant monitoring for jerry can } \\
\text { disinfection campaigns - consistently reported }\end{array}$ \\
\hline
\end{tabular}


WASH interventions are regularly implemented in combination by responders to address multiple possible transmission routes and provide comprehensive protection to beneficiaries. Overall, 13 WASH package evaluations from eight countries were identified in this review; all 13 are high bias grey literature documents and 11 are field commentary documents.

The specific interventions included in the WASH package mirror the results already described, with more water and hygiene interventions evaluated than sanitation interventions (Figure 3.28). However, the water interventions included in WASH package are not source or water treatment, as seen in the individual intervention evaluations, but well rehabilitation and water trucking. While well rehabilitation and water trucking are described as activities in WASH package interventions, they were not evaluated either as individual activities or within WASH package interventions.

\section{Figure 3.28: WASH package comparison}

\begin{tabular}{|c|c|c|c|c|c|c|c|}
\hline & 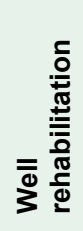 & 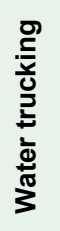 & $\begin{array}{l}\frac{0}{0} \\
\frac{2}{0} \\
\frac{0}{0} \\
\frac{0}{3} \\
z \\
\text { z }\end{array}$ & 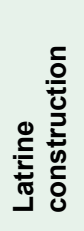 & 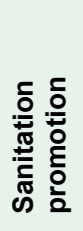 & 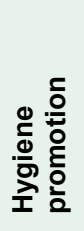 & 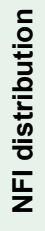 \\
\hline $\begin{array}{l}\text { DeGabriele (2009) } \\
\text { Zimbabwe }\end{array}$ & $\checkmark$ & $\checkmark$ & - & - & $\checkmark$ & - & $\checkmark$ \\
\hline $\begin{array}{l}\text { Neseni (2009) } \\
\text { Zimbabwe }\end{array}$ & $\checkmark$ & $\checkmark$ & - & $\checkmark$ & - & $\checkmark$ & $\checkmark$ \\
\hline $\begin{array}{l}\text { El-Mahmid (2009) } \\
\text { Zimbabwe }\end{array}$ & $\checkmark$ & $\checkmark$ & - & - & - & $\checkmark$ & $\checkmark$ \\
\hline $\begin{array}{l}\text { ACF }(2007) \\
\text { Somalia }\end{array}$ & $\checkmark$ & $\checkmark$ & - & - & - & $\checkmark$ & $\checkmark$ \\
\hline $\begin{array}{l}\text { ACF (2012) } \\
\text { Chad }\end{array}$ & $\checkmark$ & - & - & - & - & $\checkmark$ & $\checkmark$ \\
\hline $\begin{array}{l}\text { ACF - Grayel (2014) } \\
\text { DRC }\end{array}$ & $\checkmark$ & - & - & $\checkmark$ & - & $\checkmark$ & $\checkmark$ \\
\hline $\begin{array}{l}\text { Simpson (2009) } \\
\text { Zimbabwe }\end{array}$ & $\checkmark$ & $\checkmark$ & $\checkmark$ & - & - & $\checkmark$ & $\checkmark$ \\
\hline $\begin{array}{l}\text { ACF - Dinku (2011) } \\
\text { Ethiopia }\end{array}$ & $\checkmark$ & - & - & - & $\checkmark$ & - & $\checkmark$ \\
\hline $\begin{array}{l}\text { Gauthier (2014) } \\
\text { South Sudan }\end{array}$ & $\checkmark$ & - & - & - & $\checkmark$ & $\checkmark$ & $\checkmark$ \\
\hline $\begin{array}{l}\text { Pennacchia (2011) } \\
\text { DRC }\end{array}$ & $\checkmark$ & - & $\checkmark$ & $\checkmark$ & - & $\checkmark$ & $\checkmark$ \\
\hline $\begin{array}{l}\text { International Organization for } \\
\text { Migration (IOM) - Condor (2011) } \\
\text { Haiti }\end{array}$ & $\checkmark$ & $\checkmark$ & - & - & - & $\checkmark$ & - \\
\hline $\begin{array}{l}\text { Tearfund - Ngegba (2002) } \\
\text { Sierra Leone }\end{array}$ & $\checkmark$ & - & $\checkmark$ & $\checkmark$ & - & $\checkmark$ & - \\
\hline $\begin{array}{l}\text { ACF - Grayel (2011) } \\
\text { Haiti }\end{array}$ & - & $\checkmark$ & - & $\checkmark$ & - & $\checkmark$ & $\checkmark$ \\
\hline
\end{tabular}

From the WASH package documents, barriers and facilitators are reported with health (3) and behavioural changes (5).

Health impacts - According to clinic data, diarrhoea rates decreased by 74 percent after the WASH package intervention programme in DRC (Pennacchia et al., 2011). Similarly, the Ministry of Health reported that the cholera attack rate 'continued to decrease' with the WASH package intervention in South Sudan (Gauthier, 2014); and the case fatality rate 'dropped significantly' after the WASH package intervention in Somalia (ACF, 2007). 
Behaviour impacts - Improved hygiene behaviour was self-reported by 90 percent of beneficiaries in outbreak and endemic contexts in Zimbabwe (DeGabriele and Musa, 2009) and DRC (Pennacchia et al., 2011) respectively; although respondents in Zimbabwe acknowledged the improvements were not consistently practised. Improved water collection, handwashing and environmental hygiene practices were also self-reported in an acute watery diarrhoea response in Somalia (Dinku, 2011). Water interventions also reportedly reduced time needed to collect water, with undocumented methods (Dinku, 2011; Pennacchia et al., 2011). A hygiene kit distribution provided 'psychosocial support' to cholera-affected communities (Neseni and Guzha, 2009). Change in people's attitude, especially toward open defecation, was also noted in Sierra Leone (Ngegba, 2002).

Unique to the NGO WASH package evaluations, two practical factors for programme facilitators are consistently identified, including expert staffing (4) and rapid response timing (8).

Expert staffing - Existing country programmes from two different organizations were scaled up in response to the Zimbabwe cholera outbreak; the importance of expert staffing was documented in both evaluations (Simpson et al., 2009; El-Mahmid and Roussy, 2009). Integrating epidemiological experts into response is also noted in a DRC evaluation (Grayel, 2014). Expert staff are identified as offering surge capacity (Gauthier, 2014) to increase the scale and speed of work from non-outbreak times and offering knowledge of interventions not previously used.

Rapid response timing - Pre-positioned hygiene kits were useful for quick initial distributions of hygiene (Lantagne, 2012; Ruiz-Roman, 2009; Neseni and Guzha, 2009; DeGabriele and Musa, 2009; Simpson, 2009), but difficulty in procuring items led to delays thereafter (Neseni and Guzha, 2009). Having flexible emergency funding facilitated response in South Sudan and Haiti (Gauthier, 2014; Condor and Rana, 2011), while securing adequate funding and knowing when to trigger rapid scale up are identified as challenges (Simpson et al., 2009).

\section{WASH package summary}

In outbreak response, well rehabilitation, NFI kit distributions and hygiene promotion are the most frequently included individual interventions in these WASH package interventions; meanwhile water trucking is slightly less common and sanitation is rarely present (Figure 3.29). The qualitative field commentaries have high bias but consistent descriptions of anecdotal health impacts and non-health behaviour change impacts. Expert staffing and rapid response timing are consistently identified as critical factors for programme success.

Figure 3.29: WASH package summary

\begin{tabular}{|c|c|c|c|}
\hline Outcomes & $\begin{array}{l}\text { Number of } \\
\text { studies }\end{array}$ & $\begin{array}{l}\text { Quality of } \\
\text { evidence }\end{array}$ & Summary \\
\hline Health & 3 & Very low & Anecdotal descriptions of disease reductions \\
\hline Use & - & - & \\
\hline $\begin{array}{l}\text { Barriers and } \\
\text { facilitators }\end{array}$ & 13 & Low & $\begin{array}{l}\text { Anecdotal descriptions of behaviour adjustments and } \\
\text { psychosocial support; staffing and timing consistently } \\
\text { identified as important factors for programme success }\end{array}$ \\
\hline
\end{tabular}

3.7 BEYOND THE SCOPE OF REVIEW

The focus of this review is on population-based WASH interventions implemented for outbreak response. However, the coordination and wide range of activities carried out in outbreak response may crossover between WASH and health. Four interventions considered beyond the scope of the review - hospital-based hygiene promotion, hospital disinfection of contaminated wastewater, dead body management and contact tracing - are briefly described here because they were considered WASH interventions in some WASH package evaluations and are relevant to WASH environmental hygiene. 
Hospital-based hygiene - Researchers found that seven consecutive days of hygiene education given to cholera patients and caretakers led to significant disease reduction in an RCT in Bangladesh (George et al., 2016). The intervention, Cholera-Hospital-BasedIntervention-for-7-Days (CHoBI7), was held within the hospital and included equipping families with a hygiene kit to facilitate safe drinking water and handwashing.

Hospital wastewater disinfection - Sozzi et al. (2015) describe a 'duty of care' to protect workers and the local population from potentially very high concentrations of highly infectious diseases in Ebola and cholera patients' fluids and wastes. Two wastewater disinfection methods using $\mathrm{pH}$ adjustment and coagulation/flocculation were evaluated in cholera treatment units in Haiti. The first method used hydrated lime to disinfect and separate suspended solids. The second method used hydrochloric acid to disinfect, then aluminum sulfate to coagulate and flocculate the solids. Both methods achieved a more than 90 percent $(1 \mathrm{log})$ removal in chemical oxygen demand, suspended solids and turbidity. There was also a more than 99.9 percent $(3 \mathrm{log})$ removal in thermotolerant coliforms.

Dead body management - The 2014-2015 Ebola outbreak in West Africa highlights the risks of dead body management and unsafe burial practices. The desire for culturally normal burials adds a critical community component to dead body management. Personal protective equipment was used by burial teams in the Ebola response, but there was difficulty in balancing safe protocols with local customs and fears (Nielsen et al., 2015). In Liberia, an assessment of burial practices noted that some staff would 'overprotect' themselves with more personal protective equipment than was recommended, which only increased the overall risk disease transmission (Flachenberg et al., 2015).

Contact tracing - Contact tracing, the identification and diagnosis of people who may have come into contact with an infected person, was described as a WASH activity by some organizations but is normally considered part of health surveillance. One example of a strong contact tracing component was ACF's CLEME that was also considered to be part of community mobilization activities (ACF, 2015).

Cost-effectiveness and economic outcomes were evaluated in a limited capacity and were not able to be assessed. Cost-related outcomes were commented on, but were too heterogeneous for analysis. These are some examples.

- Acute chlorine HWT interventions cost about US\$1/day for a household with confirmed FCR in Nepal and Kenya (Lantagne and Clasen, 2012).

- In a chlorine solution project in Madagascar, a bottle of chlorine solution able to treat $1,000 \mathrm{~L}$ cost about US $\$ 0.46$ (Dunston et al., 2001). However, this price did not include promotion or indirect costs and was estimated to have 46 percent cost recovery.

- Cost of a disinfection kit was the only reported cost in an evaluation from Haiti (Gartley et al., 2013), while costs per beneficiary were calculated without the critical hygiene kit values (Gauthier, 2014).

- Vouchers (US\$70 for 2,184 households) were used in a special market day, where beneficiaries could negotiate prices and select their own items (Pennacchia et al., 2011).

- There was general uncertainty if reported 'project costs' included: staffing, indirect costs or headquarters costs.

The variety of WASH interventions is represented in the review, with 10 interventions described and evaluated. While most of these evaluations are poor quality with high bias, the strength of evidence comes from the consistency of reported outcomes (Figure 3.30). 
Figure 3.30: Intervention summary

\begin{tabular}{|c|c|c|c|c|c|}
\hline \multirow[t]{2}{*}{ Intervention } & \multicolumn{3}{|c|}{ Quality of evidence by outcomes } & \multirow[t]{2}{*}{ Conclusions } & \multirow{2}{*}{$\begin{array}{l}\text { Overall } \\
\text { evidence }\end{array}$} \\
\hline & Health & Use & $\begin{array}{l}\text { Non- } \\
\text { health }\end{array}$ & & \\
\hline Well disinfection & - & - & Moderate & $\begin{array}{l}\text { Inconsistent evaluation methods, but } \\
\text { consistent results } \\
\text { Pot chlorination with pressed chlorine } \\
\text { tablets can maintain FCR for } 3-4 \text { days } \\
\text { in a well; pot chlorination with powdered } \\
\text { chlorine also had some success }\end{array}$ & Moderate \\
\hline $\begin{array}{l}\text { Source-based } \\
\text { treatment }\end{array}$ & - & Moderate & Moderate & $\begin{array}{l}\text { Variation in reported, confirmed and } \\
\text { effective use - context specific ( } 3 \text { case } \\
\text { studies) } \\
\text { Speaking with promoter and easy } \\
\text { access to dispenser associated with } \\
\text { increased use }\end{array}$ & Moderate \\
\hline $\begin{array}{l}\text { HWT - chlorine } \\
\text { Chlorine tablets }\end{array}$ & - & Moderate & Moderate & $\begin{array}{l}\text { Low and wide range of reported and } \\
\text { confirmed use with an outlier } \\
\text { Taste and smell a hindrance } \\
\text { consistently described as a barrier }\end{array}$ & Moderate \\
\hline $\begin{array}{l}\text { HWT - chlorine } \\
\text { Liquid chlorine }\end{array}$ & - & Low & Low & $\begin{array}{l}\text { Low and wide range of reported and } \\
\text { confirmed use } \\
\text { Links with development and } \\
\text { sustainability, including prior exposure } \\
\text { and free distribution as factors }\end{array}$ & Low \\
\hline $\begin{array}{l}\text { HWT - chlorine } \\
\text { Flocculant/ } \\
\text { disinfectants }\end{array}$ & Low & Low & Low & $\begin{array}{l}\text { Use varied greatly - knowledge of use a } \\
\text { factor } \\
\text { High potential health impact with high } \\
\text { use, but in a controlled experiment with } \\
\text { weekly reporting }\end{array}$ & Low \\
\hline $\begin{array}{l}\text { HWT - other } \\
\text { filtration, SODIS, } \\
\text { safe storage and } \\
\text { boiling }\end{array}$ & Low & Very low & Low & $\begin{array}{l}\text { Limited number of interventions, but } \\
\text { higher quality evaluation methods } \\
\text { Consistently used in endemic contexts } \\
\text { with links to development. Consistent } \\
\text { positive health impact }\end{array}$ & Low \\
\hline $\begin{array}{l}\text { Community- } \\
\text { driven sanitation }\end{array}$ & Low & - & Low & $\begin{array}{l}\text { Limited number of interventions, but } \\
\text { strong positive health and social aspects } \\
\text { from community-led interventions }\end{array}$ & Low \\
\hline $\begin{array}{l}\text { Hygiene } \\
\text { promotion }\end{array}$ & Low & Very low & Low & $\begin{array}{l}\text { Consistently, personal communication } \\
\text { and radio are preferred and trusted by } \\
\text { the community } \\
\text { Use and health reportedly improved }\end{array}$ & Low \\
\hline $\begin{array}{l}\text { Social } \\
\text { mobilization }\end{array}$ & Low & - & Low & $\begin{array}{l}\text { Limited assessments but anecdotal } \\
\text { health impact } \\
\text { Community trust and ownership } \\
\text { important factors }\end{array}$ & Low \\
\hline $\begin{array}{l}\text { Hygiene kit } \\
\text { distribution }\end{array}$ & - & - & Low & $\begin{array}{l}\text { Consistent factor of influence through } \\
\text { materials, quantity and timeliness } \\
\text { Low quality evaluations, HWT primary } \\
\text { investigation of hygiene kits }\end{array}$ & Low \\
\hline $\begin{array}{l}\text { Environmental } \\
\text { hygiene }\end{array}$ & Very low & Very low & Low & $\begin{array}{l}\text { With weak evaluations, jerry can } \\
\text { disinfection consistently reported to } \\
\text { reduce disease transmission risk } \\
\text { Chlorine concentration monitoring is } \\
\text { necessary } \\
\text { Household spraying consistently not } \\
\text { recommended for responders }\end{array}$ & Very low \\
\hline WASH package & Very low & - & Low & $\begin{array}{l}\text { Weak evaluations had consistent } \\
\text { anecdotal descriptions of disease } \\
\text { reductions, behaviour adjustments and } \\
\text { psychosocial support; staffing and } \\
\text { timing also important factors }\end{array}$ & Low \\
\hline
\end{tabular}




\section{Theory of change}

WASH interventions are implemented in a variety of contexts and there is no 'silver bullet' intervention that is universally applicable in all circumstances (Clarke and Steele, 2009). Through this review, we identified $10 \mathrm{WASH}$ interventions and identified common breakages along the causal chain (Figure 3.31). All interventions were efficacious with a positive impact on WASH conditions with the exception of household spraying. Well disinfection and jerry can disinfection evaluations did not have beneficiary involvement, thus the effectiveness is limited to the local conditions and how the intervention was carried out. The remaining interventions were shown to be influenced by beneficiary factors like taste/smell, their knowledge of use, and intervention promotion.

\section{Figure 3.31: Causal chain intervention evidence. Source: The research team}

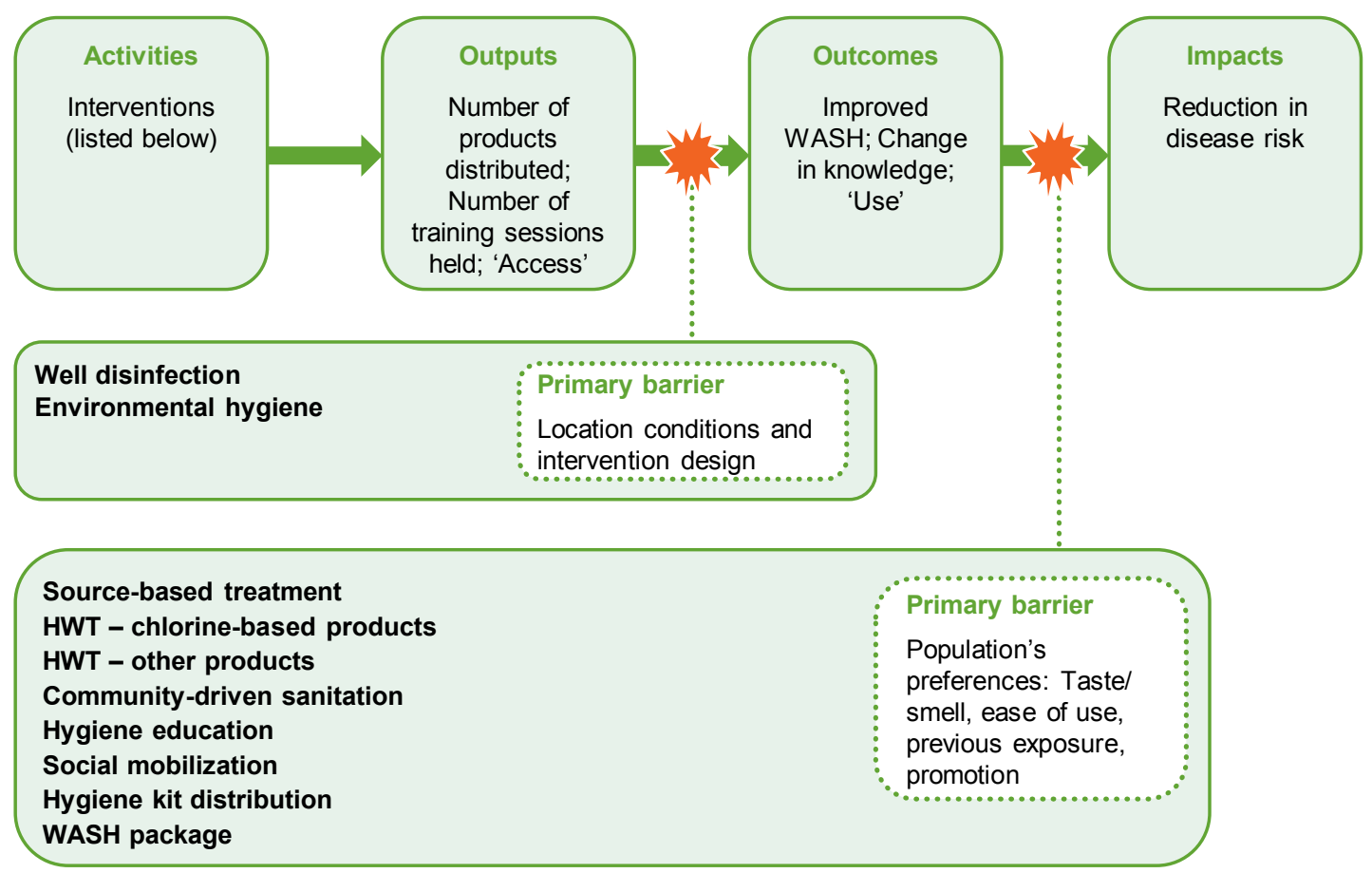




\section{DISCUSSION AND CONCLUSIONS}

A systematic process was used to identify $51 \mathrm{WASH}$ evaluations in $19 \mathrm{LMICs}$ affected by disease outbreaks. The following sections describe and summarize the research objectives (Section 4.1), limitations (Section 4.2), recommendations (Section 4.3) and conclusions (Section 4.4).

\subsection{REVIEW OBJECTIVES}

To determine effective WASH interventions in disease outbreaks, we investigated: interventions that reduce the risk of disease via outcomes and/or impacts; design and implementation characteristics associated with more effective programmes; economic outcomes; and barrier and facilitator-related outcomes that require consideration.

\section{Objective 1: WASH interventions that reduce the disease burden in outbreaks}

WASH interventions have the potential to reduce disease in outbreaks. Weak evaluation designs and limited studies explain the low quality of evidence, but interventions consistently reduce disease risk and the risk of transmission.

- Reduced disease risk - WASH interventions that evaluated health impact through a measured change in disease rates were rarely conducted in outbreaks, as only six health impact evaluations were identified in the review. Five are with less commonly implemented HWT interventions - one with PUR (Doocy and Burnham, 2006), two with simple filters (Colwell et al., 2003; Huq et al., 2010), one with SODIS (Conroy et al., 2001) and two with safe storage (Roberts et al., 2001; Doocy and Burnham, 2006). All five studies reduced disease rates. In the sixth evaluation, a long-running CLTS intervention implemented before and during the Ebola outbreak had a large and significant reduction in disease risk (Meyer Capps and Njiru, 2015).

- Reduced transmission risk - More common than disease reduction evaluations, interventions that evaluate the risk of transmission included: well disinfection (Rowe, 1998; Libessart and Hammache, 2000; Garandeau et al., 2006; Guevart et al., 2008; Cavallaro et al., 2011), chlorine dispensers (Yates, Armitage, et al., 2015), HWT (liquid chlorine (Mong et al., 2001; Dunston et al., 2001; Lantagne and Clasen, 2012; ACF 2014b), chlorine tablets (Imanishi et al., 2014; Lantagne and Clasen, 2012; ACF, 2009; Tokplo, 2015; ACF, 2014a) and flocculant/disinfectants (Doocy and Burnham, 2006; Lantagne and Clasen, 2012; ACF 2014a)). Environmental hygiene interventions using chlorine to clean jerry cans also reduced short-term transmission risk (Steele et al., 2008; Walden et al., 2005; Roberts et al., 2001).

WASH interventions consistently reduce both the risk of disease and the risk of transmission in outbreak contexts. Programme design and beneficiary preferences, described in the following sections, are important considerations to ensure WASH interventions reach their potential.

\section{Objective 2: Programme design and implementation characteristics associated with more effective programmes}

Four programme design and implementation characteristics, identified through a mixture of research designs and bias, are consistently reported as positive programme characteristics: simplicity, timing, being community driven and having links to development programmes.

- Simple - Some of the most basic interventions had a clear positive impact. Interventions requiring little to no promotion led to incremental improvements that reduced the risk of disease (Roberts et al., 2001; Colwell et al., 2003; Huq et al., 2010; Gartley et al., 2013; Lantagne and Clasen, 2012). 
- Timing - Prepositioned stock, quick release of funds and early triggers for rapid scale up were important facets of a positive response, particularly with hygiene kit and HWT interventions (Simpson et al., 2009; DeGabriele and Musa, 2009; Neseni and Guzha, 2009; Ruiz-Roman, 2009; Lantagne and Clasen, 2012).

- Community driven - Engagement in the community empowers and builds trust. Community-driven interventions can increase awareness, trigger behaviour change and identify local solutions (Waterkeyn et al., 2005; Neseni and Guzha, 2009; Rees-Gildea, 2013, Meyer Capps and Njiru, 2015; ACF, 2015; Wall and Chéry, 2011).

- Linking relief rehabilitation and development - Linking with pre-existing programming builds on recipient familiarity and having a sustainability plan encourages a better cultural understanding and improved emergency response programmes (Meyer Capps and Njiru, 2015; Dunston et al., 2001; Tokplo, 2015; Imanishi et al., 2014; Lantagne and Clasen, 2012; WHO, no date).

\section{Objective 3: Economic analysis of WASH interventions in outbreaks}

Economic outcomes of WASH interventions in outbreaks were not able to be assessed as there were only minimal economic outcomes in the evaluations included in the review.

\section{Objective 4: Barriers and facilitators that affect WASH outbreak interventions}

In the review, four community perceptions and preferences that consistently impact the success of WASH outbreak interventions were identified through a mixture of evaluation methods and quality.

- Taste and smell - Taste and smell of HWT may hinder use (e.g. chlorine treatments can have an off-putting smell or taste) (ACF, 2009; Lantagne and Clasen, 2012; Imanishi et al., 2014; Ruiz-Roman, 2009) or facilitate use (e.g. filters and flocculant/disinfectants improved taste) (Doocy and Burnham, 2006; Colwell et al., 2003; Huq et al., 2010).

- Preferred communication - Radio and face-to-face communication are consistently reported as 'most trusted' or 'most valued' for hygiene communication (Einarsdóttir et al., 2001; Date et al., 2013; WHO, no date; Contzen and Mosler, 2013; Matemo, 2014; Williams et al., 2015; Wall and Chéry, 2011).

- Perception of risk - Community understanding of some interventions overestimate the effectiveness and risk reduction (i.e. household spraying and well disinfection) (Grayel, 2011; Rowe, 1998).

- Trust/fear - Social mobilization and open communication between the community and NGOs build trust and greater community cohesion (Wall and Chéry, 2011; Waterkeyn et al., 2005; ACF, 2015).

\section{Summary of objectives}

We found that some WASH interventions are successful at reducing the risk of disease via outcomes and impacts, although programme design, implementation characteristics and community preferences are critical to programme success. Overall, the quality of evidence is low; this is attributed to weak study designs that lacked control groups and had high likelihood of spillover effects. We are not able to assess economic outcomes. Based on these results, we recommend the following.

- Responders interested in implementing outbreak programmes should: 1) use simple interventions with clear consistent messaging through several communication methods; and 2) engage in open communication with the communities to dispel fears and address local concerns.

- Policy makers should consider: the importance of fast flexible funding, the value of prepositioned hygiene kits and the importance of development/endemic interventions contributing to acute response. 
While we need more research on specific WASH interventions that are under-researched (as discussed in Section 4.3 and shown in Figure 4.1), it is anticipated that the implementation and psychosocial aspects of WASH interventions will remain critical to assess, especially for more complex WASH interventions.

Figure 4.1 describes the state of evidence identified in this review. As can be seen, water interventions, source-based treatment and HWT had more evaluations, better evidence and were assessed more quantitatively. Hygiene, sanitation and WASH package interventions were assessed with lower quality and more qualitative studies. No intervention had high quality of evidence.

Lastly, some commonly evaluated WASH interventions were not evaluated in any document included in the review, including: water supply (well rehabilitation, water trucking), latrine building, handwashing, bucket chlorination, household spraying, environmental drainage/clean-up and cost-effectiveness of any intervention.

Figure 4.1: Summary map of evidence. Source: The research team

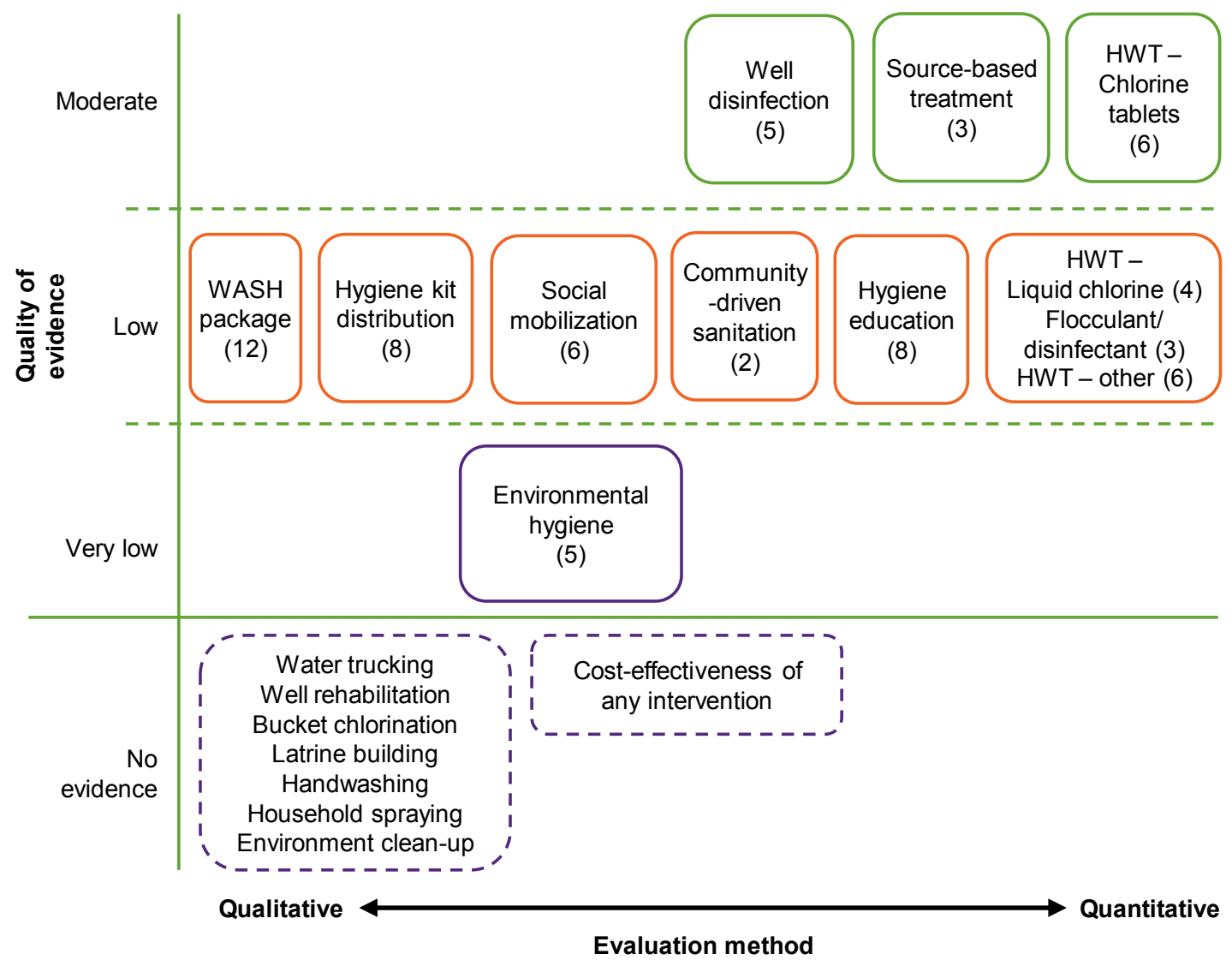

\subsection{LIMITATIONS}

This review has several limitations, including the potential for reporting bias, search bias, recall and courtesy bias, the use of proxy indicators, inconsistent outcome reporting and bias inherent in the protocol design.

Reporting bias - Most organizations that submitted documents to the review provided only a select handful of reports. It is possible that provided reports were limited to those with favourable outcomes or innovative approaches, and reports detailing mundane activities or unfavourable results were not provided. One notable exception was the organization ACF, who shared thousands of documents spanning nearly 10 years of work. Additionally, several key organizations in outbreak response did not submit documents, despite multiple efforts to collect information. It is likely that additional information is available, but was not submitted to the review process. 
Recall and courtesy bias - Self-reported data (such as diarrhoeal disease incidence or use of HWT products) is subject to both recall and courtesy bias. Recall bias occurs when beneficiaries remember occurrences differently from what actually occurred. Courtesy bias occurs when beneficiaries respond to questions with answers that are acceptable or correct, rather than accurate. These biases would likely over-estimate positive outcomes.

Use of proxy indicators - Diarrhoea incidence and prevalence and E. coli microbiological results are limited by the fact they are proxies for the outcomes and impacts of disease outbreaks.

Inconsistent outcome reporting - Outcomes (such as FCR) were reported inconsistently, and this limited the potential for comparison across evaluations. For example, confirmed use of a HWT intervention was the clearest outcome measure identified by measuring FCR; however, reporting thresholds varied by: 'detectable,' $>0.0 \mathrm{mg} / \mathrm{L},>0.1 \mathrm{mg} / \mathrm{L}, \geq 0.2 \mathrm{mg} / \mathrm{L}$, and $\geq 0.5 \mathrm{mg} / \mathrm{L}$. Additionally, WASH interventions that are intended to prevent or reduce disease transmission may have difficulty showing impact because of the difficulty in proving a negative (i.e. disease reduction) and the uncertainty of knowing future or potential disease rates. While rigorous study designs can account for these issues, they often require a control group and this leads to ethical concerns in emergency contexts.

Bias inherent in protocol design - Some biases were inherent in the search strategy as defined in the protocol (Yates, Vijcic, et al., 2015).

- Database searching was completed in English, French and Spanish. It is likely there is additional information in other languages not searched.

- Keywords searched may not have captured all relevant studies with variations of intervention names or names in local languages.

- The web-based searches were limited by the fact that organization websites were structured differently, and to the authors' knowledge there is no single web repository for research in emergencies.

- Only WASH interventions implemented in outbreak settings were included; as many WASH interventions are derived from other sectors (development, emergency response), it is likely that studies with relevant information were excluded.

- The inclusion criteria permitted a greater quantity of lower quality less technical studies than is traditional to systematic reviews. This increased the knowledge gained, but precluded meta-analysis. Previous systematic review efforts reporting only on health impacts have been limited by small sample size and few lessons learned; the broad inclusion criteria here led to disparate outcomes and impacts that were not possible to directly compare (Taylor et al., 2015; Ramesh et al., 2015).

Challenges in conducting the review - It was more difficult than expected to:

- identify whether an intervention was a WASH intervention, as activities (such as dead body management) can be considered WASH, but also can be health, nutrition and/or community mobilization

- assess whether the WASH intervention was in the same geographic location as the outbreak

- compare interventions conducted at different times in the outbreak, as outbreaks can transition from endemic to acute situations, with different WASH interventions carried out in each stage

- search and extract information from grey literature, as grey literature documents often included information beyond the scope of evaluation and lacked consistency in format, definition, structure and objective.

Despite these limitations, the strength of this review is in its broad inclusion criteria and assessment of intermediary outcomes and final impacts that led to a comprehensive review of available evidence that is policy-relevant and actionable. 

FUTURE RESEARCH

There are WASH interventions that are widely implemented, but under-researched, as evidenced by the wide disparity between the types of interventions in grey and published literature. Grey literature proved to be a valuable resource in the review, with 49 percent $(25 / 51)$ of the included contexts. Water interventions (HWT, source treatments) were well established in the academic literature. On the other hand, grey literature contributed most significantly to sanitation, hygiene and WASH package interventions. The opportunity for synergies in WASH programming is often discussed; yet the WASH package interventions had no published evaluations. WASH package interventions are complex and pose difficult considerations for research; however, the lack of any published WASH package evaluation identifies a disconnect between academic research and field evaluations.

It is clear from the results of the review that some of the most commonly implemented WASH interventions in outbreaks are severely under-researched. We need additional research for: well rehabilitation, bucket chlorination, latrine building, handwashing, household spraying, water trucking, environmental drainage/clean-up and cost-effectiveness of any intervention.

Based on the review, the following recommendations are made for future evaluations of these interventions.

- Clear reporting with consistent evaluation methods could greatly improve the quality and confidence of the interventions. The variety and heterogeneity could be minimized with common and robust methods that are widely applicable.

- Evaluations should include beneficiary input via household surveys, focus group discussions and/or key informant interviews.

- Evaluations should be conducted and reported in a timely manner to ensure lessons learned can be transferred and applied. Publication, while not necessary, does offer transparency and an additional sharing platform for the humanitarian community.

- Economic analysis should be prioritized.

- Natural experiments and comparison groups can be used to increase the quality of research in outbreak settings, for two reasons.

Natural experiments, such as occurred with the SODIS health impact study when a cholera outbreak started in the study area (Conroy et al., 2001), leverage research already being conducted to gain knowledge of efficiency and effectiveness of outbreak response.

Evaluation designs with control and intervention groups are not often used in outbreak situations because of ethical concerns and practical intervention difficulties with delivering different interventions to similar groups. The design hurdle can be minimized with a stepped-wedge research design where multiple groups are assessed then crossover from control to intervention in a step-by-step progression. This design takes advantage of the time necessary to deliver projects in a large area.

Retrospective control groups are also an option, as in the CLTS Ebola response in Liberia (Meyer Capps and Njiru, 2015).

- Evaluations on timely related research issues are needed, such as: interventions in urban areas rapid interventions in areas without water and sanitation infrastructures many of the diseases in this review have, or will soon have, available vaccines. There is an active and ongoing conversation on how to incorporate WASH and vaccine programmes, and which to prioritize (Murray, 1998). 


\subsection{CONCLUSIONS}

A systematic review process was used to identity more than 15,000 documents; ultimately, 51 evaluations of WASH interventions in outbreaks are included in the review. The majority of evaluations focus on water treatment and to a lesser extent hygiene. NGO documents (grey literature) make up nearly half $(49 \%, 25 / 51)$ of the included studies, contributing to the overall evidence base. We found that some WASH interventions are successful at reducing the risk of disease via outcomes and impacts, although programme design, implementation characteristics and community psychosocial aspects are critical to programme success. Interventions should be simple with open communication between responders and beneficiaries. The importance of quick and flexible funding, pre-positioned stock and linking development interventions to acute outbreak response are also important considerations. Overall, in outbreak contexts, there is low quality but consistent evidence that WASH interventions can reduce both the risk of disease and risk of disease transmission. 
Action Contre La Faim (ACF). (2007). UNOCHA Emergency Funding Water and Sanitation Program in Kebri Dehar District, Somali Region. Action Contre La Faim - France.

ACF. (2009). Household NFI monitoring Report (Post Distribution Monitoring (PDM)) May 2009. Action Contre La Faim - Zimbabwe.

ACF. (2014a). Hygiene Kits Post Distribution Monitoring Report. Action Contre La Faim South Sudan.

ACF. (2014b). Projet pilote de l'approche de marché pour la promotion du chlore liquide. Action Contre La Faim.

ACF. (2015). Community Led Ebola Management and Eradication (CLEME) Trigger Behavioral Change to strengthen community's resilience to Ebola Outbreaks. Action Contre La Faim.

Cavallaro, E.C., Harris J.R., et al. (2011). Evaluation of pot-chlorination of wells during a cholera outbreak, Bissau, Guinea-Bissau, 2008. Journal of Water and Health 9(2):394-402. doi: 10.2166/wh.2011.122.

Colwell, R.R., Huq, A. et al. (2003). Reduction of cholera in Bangladeshi villages by simple filtration. Proc Natl Acad Sci USA 100 (3), 1051-5. doi: 10.1073/pnas.0237386100.

Condor, J. and Rana, R. (2011). Evaluation of the International Organization for Migration's Ongoing Activities on Support to the Flash Appeal for the Haiti Earthquake and Cholera Outbreak. IOM International Organization for Migration.

Conroy, R.M., Meegan, M.E. et al. (2001). Solar disinfection of drinking water protects against cholera in children under 6 years of age. Archives of disease in childhood 85(4):293-95.

Contzen, N. and Mosler, H-J. (2013). Impact of different promotional channels on handwashing behaviour in an emergency context: Haiti post-earthquake public health promotions and cholera response. Journal of Public Health 21(6), 559-73.

Date, K., Person, B., et al. (2013). Evaluation of a Rapid Cholera Response Activity-Nyanza Province, Kenya, 2008. Journal of Infectious Diseases 208, S62-S68. doi: 10.1093/infdis/jit198.

DeGabriele, J. and Musa, A.. (2009). An emergency response to humanitarian WASHrelated emergencies in Zimbabwe. Action Contre la Faim and Welthungerhilfe Zimbabwe.

Dinku, S., (2011). Emergency Water, Sanitation, and Hygiene Interventions for AWD and Drough Affected Pastorial Communities in Borana Zone, Ethiopia. Action Contre La Faim International (ACF - IN).

Doocy, S. and Burnham G. (2006). Point-of-use water treatment and diarrhoea reduction in the emergency context: an effectiveness trial in Liberia. Tropical Medicine \& International Health 11(10), 1542-52.

Dunston, C., McAfee, D. et al. (2001). Collaboration, cholera, and cyclones: A project to improve point-of-use water quality in Madagascar. American Journal of Public Health 91 (10):1574-76. doi: 10.2105/ajph.91.10.1574.

Einarsdóttir, J., Passa, A. and Gunnlaugsson, G. (2001). Health Education and Cholera in Rural Guinea-Bissau. International Journal of Infectious Diseases 5(3), 133-38.

El-Mahmid, I. and Roussy, S. (2009). Zimbabwe Emergency Response. Action Contre la Faim.

Garandeau, R., Trevett, A. and Bastable, A. (2006). Chlorination of hand-dug wells in Monrovia. Waterlines 24(3), 19-21. 
Gartley, M., Valeh, P. et al. (2013). Uptake of household disinfection kits as an additional measure in response to a cholera outbreak in urban areas of Haiti. Journal of Water and Health 11(4), 623-28. doi: 10.2166/wh.2013.050.

Gauthier, J., 2014. A real-time evaluation of ACF's response to cholera emergency in Juba, South Sudan. Action Contre la Faim - International.

Grayel, Y. (2011). Evaluation Externe Réponse d'Urgence à L'Epidémie de Choléra en Haïti. Action Contre la Faim - International (ACF - IN).

Grayel, Y. (2014). Programme D'Intervention Pour Limiter et Prevenir la Propagation de l'Epidemie du Cholera. Action Contre la Faim - International.

Guevart, E., Van Hecke, C. et al. (2008). Handmade devices for continuous delivery of hypochlorite for well disinfection during the cholera outbreak in Douala, Cameroon (2004). Medecine tropicale: revue du Corps de sante colonial 68 (5):507-13.

Huq, A., Yunus, M. et al. (2010). Simple sari cloth filtration of water is sustainable and continues to protect villagers from cholera in Matlab, Bangladesh. MBio 1(1), doi:

10.1128/mBio.00034-10.

Imanishi, M., Patience F. et al. (2014). Household Water Treatment Uptake during a Public Health Response to a Large Typhoid Fever Outbreak in Harare, Zimbabwe. American Journal of Tropical Medicine and Hygiene 90(5), 945-54. doi: 10.4269/ajtmh.13-0497.

Lantagne, D.S. and Clasen, T.F. (2012). Use of Household Water Treatment and Safe Storage Methods in Acute Emergency Response: Case Study Results from Nepal, Indonesia, Kenya, and Haiti. Environmental Science \& Technology. 46(20), 11352-60. doi: 10.1021/es301842u.

Libessart, Y., and Youcef, H. (2000). Integrated chlorination campaign in Mogadeshu. WEDC 26.

Matemo, C. (2014). Use of H2S Tests to Monitor Water Quality in Insecure Environment. Action Contre la Faim - Kenya.

Meyer Capps, J., and Njiru, H. (2015). Open Defecation Status, Community-Led Total Sanitation and Ebola Virus Disease (EVD) in Voinjama and Kolahun Health Districts, Lofa County, Liberia (2014). Global Communities.

Mong, Y., Kaiser, R. et al. (2001). Impact of the safe water system on water quality in cyclone-affected communities in Madagascar. American Journal of Public Health 91(10), 1577-9. doi: 10.2105/ajph.91.10.1577.

Neseni, N. and Guzha, E. (2009). Evaluation of the WASH Response to the 2008-2009 Zimbabwe Cholera Epidemic and Preparedness Planning for Future Outbreaks. Institute of Water and Sanitation Development.

Ngegba, S. (2002). Water and Sanitation Programme. Tearfund UK.

Pennacchia, V., Poidatz, J. and Hearne, N.. (2011). Bridging the Gap: Providing Water and Sanitation and Non-Food Item Assistance to Returnees, IDPs and Host Communities in North Kivu.

Rees-Gildea, P. (2013). Sierra Leone Cholera ERU Operation Review. Internation Federation of Red Cross and Red Cresent Societies (IFRC).

Roberts, L., Chartier, Y. et al. (2001). Keeping clean water clean in a Malawi refugee camp: a randomized intervention trial. Bulletin of the World Health Organization 79(4), 280-87.

Rowe, A.K. (1998). Chlorinating well water with liquid bleach was not an effective water disinfection strategy in Guinea-Bissau. International Journal of Environmental Health Research 8(4):339-40. doi: 10.1080/09603129873444.

Ruiz-Roman, E. (2009). Evaluation of the Blanket Distribution of Nonfood Items as Part of the Cholera Response in Zimbabwe. UNICEF Zimbabwe. 
Simpson, R., Legesse, N.B. and Mubayiwa, R. (2009). Real Time Evaluation of the Cholera Response in Zimbabwe. Oxfam International.

Steele, A., Clarke, B. and Watkins, O. (2008). Impact of jerry can disinfection in a camp environment-experiences in an IDP camp in Northern Uganda. Journal of water and health $6(4), 559-64$.

Tokplo, H. (2015). Project de Reprise Communautaire de la Lutte Contre le Cholera et les Maladies Hydriques dans les Zones de Sante de Minova (Sud Kivu) et de Kirotshe (Nord Kivu), R.D. Congo. Action Contre la Faim - R.D. Congo.

Walden, V.M., Lamond, E.A. and Field, S.A. (2005). Container contamination as a possible source of a diarrhoea outbreak in Abou Shouk camp, Darfur province, Sudan. Disasters 29(3), 213-21.

Wall, I. and Chéry, Y.G. (2011). Ann Kite Yo Pale: Let Them Speak.

Waterkeyn, J., Okot, P. and Kwame, V. (2005). Rapid sanitation uptake in the internally displaced people camps of northern Uganda through community health clubs. WEDC 31.

World Health Organization (WHO). (no date). Guidance on communication with respect to safe drinking water and household hygiene: Literature review, interviews and case studies.

Williams, H.A., Gaines, J. et al. (2015). Perceptions of Health Communication, Water Treatment and Sanitation in Artibonite Department, Haiti, March-April 2012. PLoS ONE 10(10), 1-17. doi: 10.1371/journal.pone.0142778.

Yates, T.M., Armitage, E. et al. (2015). Effectiveness of chlorine dispensers in emergencies: case study results from Haiti, Sierra Leone, Democratic Republic of Congo and Senegal. Environ Sci Technol. 49(8), 5115-22. doi: 10.1021/acs.est.5b00309.

\section{$5.2 \quad$ OTHER STUDIES CITED IN REVIEW}

Aggarwal, R., and Sita, N. (2009). Epidemiology of hepatitis E: Current status. Journal of Gastroenterology \& Hepatology 24 (9), 1484-93. doi: 10.1111/j.1440-1746.2009.05933.x.

Ali, M., A.L. Lopez. et al. (2012). The Global Burden of Cholera. Bull World Health Organ 90 (3):209-218A. doi: 10.2471/BLT.11.093427.

Ali, S.I., and Kadir, K. (2016). WASH in Emergencies Problem Exploration Report: Water Treatment. Humanitarian Innovation Fund.

Baird, S., Ferreira, F., et al. (2013). Relative effectiveness of conditional and unconditional cash transfers for schooling outcomes in developing countries: a systematic review.

Campbell systematic reviews 9 (8).

Blanchet, K, Sistenich, V. et al. (2013). An evidence review of research on health interventions in humanitarian crises. London: London School of Hygiene \& Tropical Medicine, Harvard School of Public Health, Overseas Development Institute.

Boccia, D., Guthmann, J-P. et al. (2006). High mortality associated with an outbreak of hepatitis E among displaced persons in Darfur, Sudan. Clinical infectious diseases: an official publication of the Infectious Diseases Society of America. 42(12), 1679-84. doi: $10.1086 / 504322$.

Brown, J., Jeandron, A., et al. (2012). Evidence review and research priorities: Water, sanitation, and hygiene for emergency response. London: SHARE at London School of Hygiene \& Tropical Medicine.

Cairncross, S., Cumming, O., et al. (2013). Water, Sanitation and Hygiene Evidence Paper. In Evidence Paper: Department for International Development.

Darcy, J., Stobaugh, H., et al. (2013). The Use of Evidence in Humanitarian Decision Making ACAPS Operational Learning Paper. Feinstein International Centre. 
de Vries, D.H., Rwemisisi, J.T. et al. (2016). The first mile: community experience of outbreak control during an Ebola outbreak in Luwero District, Uganda. BMC Public Health 16:161. doi: 10.1186/s12889-016-2852-0.

Dunoyer, J. and Sudre, B. (2012). Le choléra au Tchad en 2011 et les stratégies d'intervention associées. Action Contre la Faim - France.

Flachenberg, F., Davis, R., Duffy, M. and Tamming, R. (2015). Hygiene promotion in Ebola: embedding best practices for safe and dignified burials, the case of Freetown, Sierra Leone. Water, Engineering and Development Centre (WEDC) Loughborough University of Technology 38.

Gaffga, N.H. , Tauxe, R.V. and Mintz, E.D. (2007). Cholera: A New Homeland in Africa? American Journal of Tropical Medicine and Hygiene 77(4), 705-13.

George, C.M, Shirajum, M., et al. (2016). Randomized controlled trial of hospital-based hygiene and water treatment intervention (CHoBI7) to reduce cholera. Emerging Infectious Diseases 22, 233+.

GIDEON. (2016). Global Infectious Disease and Epidemiology Online Network. http://www.gideononline.com/.

Godfrey, S., McCaffery, L. et al. (2003). The Effectiveness of Point-Source Chlorination in Improving Water Quality in Internally Displaced Communities in Angola. Water and Environment Journal 17(3), 149-51.

Grange, C. (2016). WASH in Emergencies Problem Exploration Report: Faecal Sludge Management. Humanitarian Innovation Fund.

Hakim, M.S., Wang, W. et al. (2016). The global burden of hepatitis $E$ outbreaks: a systematic review. Liver Int. doi: 10.1111/liv.13237.

Higgins, J.P.T. and Green, S. (2008). Cochrane handbook for systematic reviews of interventions. Vol. 5: Wiley Online Library.

Joint Monitoring Program (JMP). (2014). Progress on Drinking Water and Sanitation 2014 Update. Geneva, Switzerland.

Kaur, M. (2016). Cholera Case Control Studies: A Systematic Review and Analysis. Master of Science, Civil and Enviornmental Engineering Tufts University.

Legrand, J., Grais, R.F. et al. (2007). Understanding the dynamics of Ebola epidemics. Epidemiology and Infection 135(4), 610-21. doi: 10.1017/S0950268806007217.

Loo, S, Fane, A.G., Krantz, W.B. and Lim, T-T. (2012). Emergency water supply: a review of potential technologies and selection criteria. Water research 46(10), 3125-51. doi:

10.1016/j.watres.2012.03.030.

Murray, J., McFarland, D.A. and Waldman, R.J. (1998). Cost-effectiveness of oral cholera vaccine in a stable refugee population at risk for epidemic cholera and in a population with endemic cholera. Bulletin of the World Health Organization 76(4), 343-52.

Nielsen, C.F., Kidd, S. et al. (2015). Improving Burial Practices and Cemetery Management During an Ebola Virus Disease Epidemic - Sierra Leone, 2014. Morbidity and Mortality Weekly Report 64 (1), 20-7.

Oxfam. (2014). Turning the tide on Ebola: Scaling up public health campaigns before it's too late. Oxfam.

Oxman, A.D. and GRADE Working Group. (2004). Grading quality of evidence and strength of recommendations. BMJ. 328(19), 1490-4.

Parkinson, J. (2009). A Review of the Evidence Base for WASH interventions in Emergency Responses. 
Ramesh, A., Blanchet, K., et al. (2015). Evidence on the Effectiveness of Water, Sanitation, and Hygiene (WASH) Interventions on Health Outcomes in Humanitarian Crises: A Systematic Review. PLoS ONE 10(9), 1-20. doi: 10.1371/journal.pone.0124688.

Ramos, M., Benelli, P., Irvine, E. and Watson, J. (2016). WASH in Emergencies Problem Exploration Report: Handwashing. Humanitarian Innovation Fund.

Reed, B, and Mena-Moreno, R. (2016). WASH in Emergencies Problem Exploration Report: Solid Waste Management. Humanitarian Innovation Fund.

Rowe, A.K. (1998). Chlorinating well water with liquid bleach was not an effective water disinfection strategy in Guinea-Bissau. International Journal of Environmental Health Research 8(4):339-40. doi: 10.1080/09603129873444.

Smith, K.F., Goldberg, M. et al. (2014). Global rise in human infectious disease outbreaks. Journal of The Royal Society Interface. 11(101), 20140950. doi: 10.1098/rsif.2014.0950.

Spencer, L., Ritchie, J., Lewis, J. and Dillon, L. (2003). Quality in qualitative evaluation: a framework for assessing research evidence.

Sphere Project. (2011). Sphere Handbook: Humanitarian Charter and Minimum Standards in Disaster Response. 3rd ed. Sphere Project.

Steele, A. and Clarke, B. (2008). Problems of treatment process selection for relief agency water supplies in an emergency. Journal of Water and Health 6(4), 483-9.

Taylor, D.L., Kahawita, T.M, Cairncross, S. and Ensink J. (2015). The Impact of Water, Sanitation and Hygiene Interventions to Control Cholera: A Systematic Review. PLoS ONE. 10(8), 1-19. doi: 10.1371/journal.pone.0135676.

Tota-Maharaj, K. (2016). WASH in Emergencies Problem Exploration Report: Surface Water Drainage. Humanitarian Innovation Fund.

UNICEF. (2013). Cholera Toolkit. edited by Programme Division. New York.

Water 1st International. (2015). Paths of Disease Transmission. Retrieved 14 May 2016. http://water1st.org/problem/f-diagram/.

Watson, J.T., Gayer, M. and Connolly, M.A. (2007). Epidemics after Natural Disasters. Emerging Infectious Diseases. 13(1):1-5.

WHO (2014). Health Facility Information Systems Resource Kit. Geneva, Switzerland: World Health Organization, US Agency for International Development (USAID), University of Oslo.

WHO. (2016a). Cholera case fatality rate: Situation and trends. WHO Retrieved 14 July 2016. http://www.who.int/gho/epidemic_diseases/cholera/case_fatality_rate_text/en/.

WHO. (2016b). Disease Outbreaks. WHO. Retrieved 14 July 2016.

http://www.who.int/topics/disease_outbreaks/en/.

WHO. (2016c). Ebola Situation Reports. WHO Retrieved 15 May 2016.

http://apps.who.int/ebola/ebola-situation-reports.

WHO. (2016d). Global Health Observatory (GHO) Data: Number of reported cholera cases. Retrieved 25 June 2016. http://www.who.int/gho/epidemic_diseases/cholera/cases_text/en/.

Yates, T., Vijcic, J. et al. (2015). Impact of WASH interventions during disease outbreaks in humanitarian emergencies: A systematic review protocol. Oxfam. 


\section{APPENDIX A - DESCRIPTION OF INCLUDED EVALUATIONS}

\begin{tabular}{|c|c|c|c|c|}
\hline Intervention & Quantitative & Qualitative & $\begin{array}{c}\text { Field } \\
\text { commentary }\end{array}$ & $\begin{array}{l}\text { Published or grey } \\
\text { literature (P:G) }\end{array}$ \\
\hline WATER & 23 & 2 & 1 & $21: 5$ \\
\hline Well disinfection & 2 & 2 & 1 & $5: 0$ \\
\hline Source-based treatment & 3 & 0 & 0 & $3: 0$ \\
\hline $\begin{array}{l}\text { HWT - chlorine based } \\
\text { products - chlorine tablets }\end{array}$ & 6 & 0 & 0 & $3: 3$ \\
\hline $\begin{array}{l}\text { HWT - chlorine based } \\
\text { products - liquid chlorine }\end{array}$ & 4 & 0 & 0 & $3: 1$ \\
\hline $\begin{array}{l}\text { HWT -chlorine based } \\
\text { products - PUR® }\end{array}$ & 3 & 0 & 0 & $2: 1$ \\
\hline HWT - other products & 5 & 0 & 0 & $5: 0$ \\
\hline SANITATION & 1 & 0 & 1 & $1: 1$ \\
\hline Community-driven sanitation & 1 & 0 & 1 & $1: 1$ \\
\hline HYGIENE & 6 & 5 & 9 & $7: 13$ \\
\hline Hygiene education & 3 & 2 & 3 & $4: 4$ \\
\hline Social mobilization & 1 & 1 & 4 & $0: 6$ \\
\hline Hygiene kit distribution & 1 & 0 & 1 & $0: 2$ \\
\hline Environmental hygiene & 1 & 2 & 1 & $3: 1$ \\
\hline WASH (package) & 0 & 3 & 9 & $0: 12$ \\
\hline WASH (package) & 0 & 3 & 9 & $0: 12$ \\
\hline Totals & 30 & 10 & 20 & 29:31 \\
\hline
\end{tabular}

Studies may be included in more than one category.

Note: Published refers to studies that have been peer-reviewed and are in the academic literature. Grey literature is any study that is not found in the academic literature - often from NGOs involved in outbreak response. 
WATER

Well disinfection

\begin{tabular}{|c|c|c|c|c|c|}
\hline $\begin{array}{l}\text { Author (year) title } \\
\text { Type }\end{array}$ & Context & $\begin{array}{l}\text { Description of } \\
\text { activities }\end{array}$ & Evaluation & Key impacts & $\begin{array}{l}\text { Bias } \\
\text { Comments }\end{array}$ \\
\hline $\begin{array}{l}\text { Rowe (1998) } \\
\text { Chlorinating well } \\
\text { water with liquid } \\
\text { bleach was not an } \\
\text { effective water } \\
\text { disinfection strategy } \\
\text { in Guinea-Bissau } \\
\text { Published }\end{array}$ & $\begin{array}{l}\text { Cholera } \\
\text { Guinea- } \\
\text { Bissau } \\
\text { Endemic }\end{array}$ & $\begin{array}{l}\text { Liquid chlorine } \\
\text { ('bleach' sodium } \\
\text { hypochlorite) } \\
\text { 'shock' dose } \\
\text { added to shallow } \\
\text { wells to achieve } \\
\text { about } 30 \mathrm{mg} / \mathrm{L}\end{array}$ & $\begin{array}{l}\text { Qualitative } \\
10 \text { wells monitored } \\
\text { every } 24 \text { hours } \\
\text { until FCR cessed }\end{array}$ & $\begin{array}{l}40 \% \text { ( } 4 / 10 \text { wells) had FCR after } 24 \\
\text { hours (median } 24 \text { hours; range } 0-6 \\
\text { days) } \\
\text { Perception of protection in the } \\
\text { community after 'well shock' is } \\
\text { beyond the protective capabilities of } \\
\text { the treatment } \\
\text { 'Well shock' may not be effective for } \\
\text { disinfecting water }\end{array}$ & $\begin{array}{l}\text { High risk of } \\
\text { bias } \\
\text { Low sample } \\
\text { size, collection } \\
\text { procedures } \\
\text { questionable }\end{array}$ \\
\hline $\begin{array}{l}\text { Libessart (2000) } \\
\text { Integrated } \\
\text { chlorination campaign } \\
\text { in Mogadishu } \\
\text { Published }\end{array}$ & $\begin{array}{l}\text { Cholera } \\
\text { Somalia } \\
\text { Endemic }\end{array}$ & $\begin{array}{l}\text { Shallow wells } \\
\text { treated with } 3 \\
\text { different chlorine } \\
\text { treatment } \\
\text { methods: } \\
\text { 1) } 1 \% \text { liquid } \\
\text { chlorine 'shock,' 2) } \\
\text { Jerry can pot } \\
\text { chlorination with } \\
\text { powdered } \\
\text { chlorine, } 3 \text { ) pot } \\
\text { chlorination with } \\
\text { immersed pressed } \\
\text { tablets (125g } \\
\text { HTH) }\end{array}$ & $\begin{array}{l}\text { Quantitative } \\
\text { FCR measured at } \\
\text { different times } \\
\text { over several } \\
\text { programming } \\
\text { cycles: } 1 \text { ) } 1 \% \\
\text { liquid chlorine: } 173 \\
\text { wells over } 1 \text { year; } \\
\text { 2) Jerry can pot } \\
\text { chlorination: } 919 \\
\text { tests over } 3 \\
\text { month; } 3 \text { ) Pressed } \\
\text { tablet pot } \\
\text { chlorination: } 98 \\
\text { tests (duration not } \\
\text { reported) }\end{array}$ & $\begin{array}{l}\text { Liquid chlorine: } 69 \% \text { measured FCR } \\
>0.1 \mathrm{mg} / \mathrm{L}(28 \%>0.6 \mathrm{mg} / \mathrm{L}) \\
\text { Jerry can pot chlorination: } 87 \% \\
\text { measured } \mathrm{FCR}>0.1 \mathrm{mg} / \mathrm{L}(27 \% \\
>0.6 \mathrm{mg} / \mathrm{L}) \\
\text { Pressed tablet pot chlorination: } 96 \% \\
\text { measured FCR }>0.1 \mathrm{mg} / \mathrm{L}(45 \% \\
>0.6 \mathrm{mg} / \mathrm{L}) \\
\text { Pressed tablet pot chlorination } \\
\text { deemed best option }\end{array}$ & $\begin{array}{l}\text { High risk of } \\
\text { bias } \\
\text { High number of } \\
\text { samples, } \\
\text { inconsistent/no } \\
\text { n-comparable } \\
\text { methods of } \\
\text { evaluation for } \\
\text { each treatment }\end{array}$ \\
\hline $\begin{array}{l}\text { Garandeau (2006) } \\
\text { Chlorination of hand- } \\
\text { dug wells in Monrovia } \\
\text { Published }\end{array}$ & $\begin{array}{l}\text { Cholera } \\
\text { Liberia } \\
\text { Endemic }\end{array}$ & $\begin{array}{l}4 \text { well chlorination } \\
\text { techniques } \\
\text { assessed: } \\
\text { 1) Floating pot } \\
\text { chlorinators; 2) } \\
\text { Jerry can pot } \\
\text { chlorination- with } \\
\text { calcium } \\
\text { hypochlorite } \\
\text { powder; 3) Liquid } \\
\text { chlorine 'bleach' - } \\
5 \% \text { solution twice } \\
\text { per day; 4) Pot } \\
\text { chlorination with } \\
\text { local pressed } \\
\text { calcium } \\
\text { hypochlorite tablet } \\
70 \mathrm{~g} \text { in bag of sand }\end{array}$ & $\begin{array}{l}\text { Qualitative } \\
12 \text { wells ( } 3 \\
\text { protected and } 9 \\
\text { unprotected) used } \\
\text { over } 9 \text { weeks with } \\
\text { different } \\
\text { chlorination } \\
\text { techniques, FCR } \\
\text { measured }\end{array}$ & $\begin{array}{l}\text { 1) Floating pot chlorinators - fairly } \\
\text { effective and appropriate but less } \\
\text { sustainable } \\
\text { 2) Simple pot - appropriate but } \\
\text { ineffective as the tablets dissolved } \\
\text { too quickly, high spike in FCR } \\
\text { 3) Liquid bleach - fairly effective but } \\
\text { FCR did not stay above } 0.2 \mathrm{mg} / \mathrm{L} \text { all } \\
\text { day } \\
\text { 4) Pressed tablet pot chlorination } \\
\text { with local pressed tablet - effective } \\
\text { and appropriate FCR } 0.2-1.0 \mathrm{mg} / \mathrm{L} \text { in } \\
\text { all wells for } 3-6 \text { days, local materials } \\
\text { and cheap } \\
\text { Locally pressed calcium hypochlorite } \\
\text { tablets in bag of sand was most } \\
\text { effective with sustained FCR for } \\
\text { several days }\end{array}$ & $\begin{array}{l}\text { High risk of } \\
\text { bias } \\
\text { Unspecified } \\
\text { methodology } \\
\text { and sampling }\end{array}$ \\
\hline $\begin{array}{l}\text { Guevart (2008) } \\
\text { Handmade devices } \\
\text { for continuous } \\
\text { delivery of } \\
\text { hypochlorite for well } \\
\text { disinfection during the } \\
\text { cholera outbreak in } \\
\text { Douala, Cameroon } \\
\text { (2004) } \\
\text { Published }\end{array}$ & $\begin{array}{l}\text { Cholera } \\
\text { Cameroon } \\
\text { Outbreak }\end{array}$ & $\begin{array}{l}\text { Pot chlorination } \\
\text { with perforated } \\
\text { plastic bag, } \\
\text { sodium } \\
\text { hypochlorite, and } \\
\text { sand }\end{array}$ & $\begin{array}{l}\text { Quantitative } \\
18 \text { wells ( } 2 \text { villages } \\
-9 \text { wells each) } 36 \\
\text { chlorinations - } \\
\text { FCR measured } \\
\text { daily }\end{array}$ & $\begin{array}{l}\text { FCR remained above } 0.2 \mathrm{mg} / \mathrm{L} \text { for } 3 \\
\text { days, after } 4 \text { days half of the wells } \\
\text { were below } 0.2 \mathrm{mg} / \mathrm{L} \\
\text { Maximum concentration occurred } \\
\text { after } 1 \text { day in } 31 / 36 \text { tests, after } 2 \\
\text { days for } 5 / 36\end{array}$ & $\begin{array}{l}\text { Low risk of bias } \\
\text { Clear well } \\
\text { selection } \\
\text { criteria, clear } \\
\text { methods and } \\
\text { reporting }\end{array}$ \\
\hline $\begin{array}{l}\text { Cavallaro (2011) } \\
\text { Evaluation of pot- } \\
\text { chlorination of wells } \\
\text { during a cholera } \\
\text { outbreak, Bissau, } \\
\text { Guinea-Bissau, } 2008 \\
\text { Published }\end{array}$ & $\begin{array}{l}\text { Cholera } \\
\text { Guinea- } \\
\text { Bissau } \\
\text { Outbreak }\end{array}$ & $\begin{array}{l}\text { Pot chlorination } \\
\text { with } 1.5 \mathrm{~L} \text { plastic } \\
\text { bottles, sodium } \\
\text { hypochlorite, } \\
\text { gravel, and sand }\end{array}$ & $\begin{array}{l}\text { Quantitative } \\
30 \text { wells - FCR } \\
\text { and TCR } \\
\text { measured daily for } \\
1-3 \text { days after } \\
\text { inserting } \\
\text { chlorinator }\end{array}$ & $\begin{array}{l}\text { Effectiveness described as } \\
\text { sustained FCR above } 1.0 \mathrm{mg} / \mathrm{L} \\
\text { (WHO outbreak guideline) } \\
\text { After } 24 \mathrm{hrs:} 15 \% \text { had FCR } \\
>1.0 \mathrm{mg} / \mathrm{L} \\
\text { After } 48 \mathrm{hrs:} 4 \% \text { had } \mathrm{FCR}>1.0 \mathrm{mg} / \mathrm{L} \\
\text { After } 72 \mathrm{hrs:} 0 \% \text { had } \mathrm{FCR}>1.0 \mathrm{mg} / \mathrm{L}\end{array}$ & $\begin{array}{l}\text { Low risk of bias } \\
\text { Clear collection } \\
\text { procedures }\end{array}$ \\
\hline
\end{tabular}




\section{Source-based treatment}

\begin{tabular}{|c|c|c|c|c|c|}
\hline $\begin{array}{l}\text { Author (year) title } \\
\text { Type }\end{array}$ & Context & $\begin{array}{l}\text { Description of } \\
\text { activities }\end{array}$ & Evaluation & Key impacts & $\begin{array}{l}\text { Bias } \\
\text { Comments }\end{array}$ \\
\hline $\begin{array}{l}\text { Yates (2015) } \\
\text { Effectiveness of } \\
\text { chlorine dispensers in } \\
\text { emergencies: Case } \\
\text { Study DRC } \\
\text { Published }\end{array}$ & $\begin{array}{l}\text { Cholera } \\
\text { DRC } \\
\text { Endemic }\end{array}$ & $\begin{array}{l}\text { Chlorine dispenser } \\
\text { installed on paths } \\
\text { near river/lake with } \\
\text { promotion }\end{array}$ & $\begin{array}{l}\text { Quantitative } \\
\text { Mixed-methods } \\
300 \mathrm{HH} \text { (initial and } \\
\text { sustained); Focus } \\
\text { group discussion } \\
\text { (FGD); Key } \\
\text { informant interview } \\
\text { (KII) }\end{array}$ & $\begin{array}{l}52 \% \text { and } 9 \% \text { reported use (initial and } \\
\text { sustained) } \\
34 \% \text { and } 5 \% \text { confirmed use (initial } \\
\text { and sustained) } \\
28 \% \text { and } 0 \% \text { effective use (initial and } \\
\text { sustained) }\end{array}$ & $\begin{array}{l}\text { Low risk of bias } \\
\text { Large } \\
\text { difference in } \\
\text { municipal water } \\
\text { supply access } \\
\text { between } \\
\text { evaluations }\end{array}$ \\
\hline $\begin{array}{l}\text { Yates (2015) } \\
\text { Effectiveness of } \\
\text { chlorine dispensers in } \\
\text { emergencies: Case } \\
\text { Study Sierra Leone } \\
\text { Published }\end{array}$ & $\begin{array}{l}\text { Cholera } \\
\text { Sierra } \\
\text { Leone } \\
\text { Endemic }\end{array}$ & $\begin{array}{l}\text { Chlorine dispenser } \\
\text { installed at } \\
\text { community wells } \\
\text { with promotion }\end{array}$ & $\begin{array}{l}\text { Quantitative } \\
\text { Mixed-methods } \\
300 \mathrm{HH} \text { (initial and } \\
\text { sustained); FGD; } \\
\text { KII }\end{array}$ & $\begin{array}{l}17 \% \text { and } 22 \% \text { reported use (initial } \\
\text { and sustained) } \\
11 \% \text { and } 18 \% \text { confirmed use (initial } \\
\text { and sustained) } \\
10 \% \text { and } 10 \% \text { effective use (initial } \\
\text { and sustained) }\end{array}$ & $\begin{array}{l}\text { Low risk of bias } \\
\text { Clear methods } \\
\text { and reporting }\end{array}$ \\
\hline $\begin{array}{l}\text { Yates (2015) } \\
\text { Effectiveness of } \\
\text { chlorine dispensers in } \\
\text { emergencies: Case } \\
\text { Study Haiti } \\
\text { Published }\end{array}$ & $\begin{array}{l}\text { Cholera } \\
\text { Haiti } \\
\text { Outbreak }\end{array}$ & $\begin{array}{l}\text { Chlorine dispenser } \\
\text { installed at high } \\
\text { risk sources. Pilot } \\
\text { progamme }\end{array}$ & $\begin{array}{l}\text { Quantitative } \\
\text { Mixed-methods } \\
298 \mathrm{HH} \\
\text { (sustained); FGD; } \\
\text { KII }\end{array}$ & $\begin{array}{l}12 \% \text { reported use (sustained) } \\
9 \% \text { confirmed use (sustained) } \\
5 \% \text { effective use (sustained) }\end{array}$ & $\begin{array}{l}\text { Low risk of bias } \\
\text { Clear methods } \\
\text { and reporting }\end{array}$ \\
\hline
\end{tabular}

HWT - chlorine-based products: chlorine tablets

\begin{tabular}{|c|c|c|c|c|c|}
\hline $\begin{array}{l}\text { Author (year) title } \\
\text { Type }\end{array}$ & Context & $\begin{array}{l}\text { Description of } \\
\text { activities }\end{array}$ & Evaluation & Key impacts & $\begin{array}{l}\text { Bias } \\
\text { Comments }\end{array}$ \\
\hline $\begin{array}{l}\text { ACF (2009) } \\
\text { Household NFI } \\
\text { monitoring report } \\
\text { (PDM) May } 2009 \\
\text { Grey literature }\end{array}$ & $\begin{array}{l}\text { Cholera } \\
\text { Zimbabwe } \\
\text { Outbreak }\end{array}$ & $\begin{array}{l}\text { Aquatabs }{ }^{\circledR} \\
\text { distributed to } \mathrm{HH} \\
\text { as part of an } \mathrm{NFI} \\
\text { kit with bucket } \\
\text { and lid }(\sim 33,000 \\
\text { kits, other } \\
\text { contents not } \\
\text { described) }\end{array}$ & $\begin{array}{l}\text { Quantitative } \\
\text { Cross-sectional: } \\
218 \mathrm{HH} \text { (random) }\end{array}$ & $\begin{array}{l}26 \% \text { of } \mathrm{HH} \text { reported use } \\
17 \% \text { of } \mathrm{HH} \text { confirmed use (FCR } \\
>0.5 \mathrm{mg} / \mathrm{L} \text { ) } \\
\text { Low Aquatab® use because water was } \\
\text { collected from a borehole 'safe water' } \\
75 \% \text { of } \mathrm{HH} \text { used the bucket } \\
\text { Overdosing, with smell and taste being } \\
\text { issues }\end{array}$ & $\begin{array}{l}\text { High risk of bias } \\
\text { Inconsistent } \\
\text { reporting, self- } \\
\text { reported } \\
\text { information, } \\
\text { FCR was } \\
\text { measured but } \\
\text { not fully } \\
\text { reported }\end{array}$ \\
\hline $\begin{array}{l}\text { Lantagne (2012) Use } \\
\text { of Household Water } \\
\text { Treatment and Safe } \\
\text { Storage Methods in } \\
\text { Acute Emergency } \\
\text { Response: Case } \\
\text { Study Nepal } \\
\text { Published }\end{array}$ & $\begin{array}{l}\text { Cholera } \\
\text { Nepal } \\
\text { Outbreak }\end{array}$ & $\begin{array}{l}\text { Local NGOs using } \\
\text { pre-positioned } \\
\text { stock. } 1565 \mathrm{HH} \text { - } \\
\text { received } \\
\text { Aquatabs } ® \text { but } \\
\text { also liquid } \\
\text { chlorine (Water } \\
\text { Guard, Piyush) }\end{array}$ & $\begin{array}{l}\text { Quantitative } \\
\text { Cross-sectional: } \\
400 \mathrm{HH}\end{array}$ & $\begin{array}{l}\text { 8.3\% reported use (Liquid Chlorine: } \\
\text { WaterGuard: } 6.3 \% \text { Piyush: } 15.8 \% \text { ) } \\
\text { 6.8\% confirmed use (FCR } \geq 0.2 \mathrm{mg} / \mathrm{L} \text { ) } \\
\text { (liquid chlorine: WaterGuard: } 3.5 \% \text {; } \\
\text { Piyush: } 8.3 \% \text { ) }\end{array}$ & $\begin{array}{l}\text { Low risk of bias } \\
\text { Spillover } \\
\text { between } \\
\text { several similar } \\
\text { interventions }\end{array}$ \\
\hline $\begin{array}{l}\text { Lantagne (2012) Use } \\
\text { of Household Water } \\
\text { Treatment and Safe } \\
\text { Storage Methods in } \\
\text { Acute Emergency } \\
\text { Response: Case } \\
\text { Study Kenya } \\
\text { Published }\end{array}$ & $\begin{array}{l}\text { Cholera } \\
\text { Kenya } \\
\text { Outbreak }\end{array}$ & $\begin{array}{l}\text { Pre-positioned } \\
\text { stock. Distribution } \\
\text { of Aquatabs } ® \text { and } \\
\text { PUR® Purifier of } \\
\text { Water in an NFI } \\
\text { kit to } 5,592 \mathrm{HH}\end{array}$ & $\begin{array}{l}\text { Quantitative } \\
\text { Cross-sectional: } \\
409 \mathrm{HH}\end{array}$ & $\begin{array}{l}12.7 \% \text { reported use (PUR® Purifier of } \\
\text { Water: } 5.9 \% \text { ) } \\
7.9 \% \text { confirmed use (PUR®: } 3.7 \% \text { ) } \\
\text { (FCR } \geq 0.2 \mathrm{mg} / \mathrm{L} \text { ) } \\
5.3 \% \text { effective use }<1 \text { CFU } 100 \mathrm{~mL} \\
\text { (PUR: } 2.3 \% \text { ) }\end{array}$ & $\begin{array}{l}\text { Low risk of bias } \\
\text { Selection bias } \\
\text { not likely, clear } \\
\text { and consistent } \\
\text { reporting of } \\
\text { outcomes }\end{array}$ \\
\hline $\begin{array}{l}\text { ACF (2014) Hygiene } \\
\text { Kits Post Distribution } \\
\text { Monitoring Report } \\
\text { Grey literature }\end{array}$ & $\begin{array}{l}\text { Cholera } \\
\text { South } \\
\text { Sudan } \\
\text { Outbreak }\end{array}$ & $\begin{array}{l}\text { Aquatabs }{ }^{\circledR} \\
\text { distributed in NFI } \\
\text { kits to } 7,348 \mathrm{HH} \text {. } \\
\text { Kit also included: } \\
\text { bucket, PUR® } \\
\text { Purifier of Water } \\
\text { packets and filter } \\
\text { cloth }\end{array}$ & $\begin{array}{l}\text { Quantitative } \\
\text { Cluster cross- } \\
\text { sectional: } 351 \mathrm{HH}\end{array}$ & $\begin{array}{l}87 \% \text { confirmed use }(>0.1 \mathrm{mg} / \mathrm{L}) \text { in } \mathrm{HH} \\
\text { with Aquatabs }(6 \% \text { of } \mathrm{HH} \text { FCR } \\
>0.5 \mathrm{mg} / \mathrm{L}) \\
>90 \% \text { of } \mathrm{HH} \text { had } \mathrm{FCR} \text { in Juba (range } \\
83-100 \%) \\
78 \% \text { of } \mathrm{HH} \text { could demonstrate correct } \\
\text { use of PUR } \\
\mathrm{HH} \text { without FCR said they get water } \\
\text { from a treated tanker, or are saving the } \\
\text { Aquatabs } ® \text { for when cholera outbreaks } \\
\text { again }\end{array}$ & $\begin{array}{l}\text { High risk of bias } \\
\text { Inconsistent } \\
\text { reporting, } \\
\text { spillover effects } \\
\text { likely }\end{array}$ \\
\hline
\end{tabular}




\begin{tabular}{|c|c|c|c|c|c|}
\hline $\begin{array}{l}\text { Author (year) title } \\
\text { Type }\end{array}$ & Context & $\begin{array}{l}\text { Description of } \\
\text { activities }\end{array}$ & Evaluation & Key impacts & $\begin{array}{l}\text { Bias } \\
\text { Comments }\end{array}$ \\
\hline $\begin{array}{l}\text { Imanishi (2014) } \\
\text { Household Water } \\
\text { Treatment Uptake } \\
\text { during a Public Health } \\
\text { Response to a Large } \\
\text { Typhoid Fever } \\
\text { Outbreak in Harare, } \\
\text { Zimbabwe } \\
\text { Published }\end{array}$ & $\begin{array}{l}\text { Typhoid } \\
\text { Zimbabwe } \\
\text { Outbreak }\end{array}$ & $\begin{array}{l}\text { Chlorine tablet } \\
\text { distributed to } \\
51,000 \mathrm{HH}(3 \\
\text { different doses); } \\
3,500 \mathrm{HH} \\
\text { received NFI kits } \\
\text { with soap, } \\
\text { WaterMaker® } \\
\text { (floc/dis), and } \\
\text { jerry can in } \\
\text { addition to HWT }\end{array}$ & $\begin{array}{l}\text { Quantitative } \\
\text { Cross-sectional: } \\
458 \mathrm{HH}\end{array}$ & $\begin{array}{l}31 \% \text { reported use } \\
22 \% \text { confirmed use (FCR } \geq 0.2 \mathrm{mg} / \mathrm{L} \text { ) } \\
73 \% \text { of } \mathrm{HH} \text { reported using } \mathrm{HWT} \text { before } \\
\text { outbreak, } 83 \% \text { reported using } \mathrm{HWT} \\
\text { during the outbreak } \\
97 \% \text { of } \mathrm{HH} \text { with stored water had } \\
\text { covered containers }\end{array}$ & $\begin{array}{l}\text { Medium risk of } \\
\text { bias } \\
\text { Carried out in } \\
\text { worst hit areas, } \\
\text { peak of } \\
\text { outbreak } \\
\text { already } \\
\text { declining }\end{array}$ \\
\hline $\begin{array}{l}\text { ACF - Tokplo (2015) } \\
\text { Projet de reprise } \\
\text { communautaire de la } \\
\text { lutte contre le choléra } \\
\text { et les maladies } \\
\text { hydriques dans les } \\
\text { zones de santé de } \\
\text { Minova (Sud Kivu) et } \\
\text { de Kirotshe (Nord } \\
\text { Kivu), D.R. Congo } \\
\text { Grey literature }\end{array}$ & $\begin{array}{l}\text { Cholera } \\
\text { DRC } \\
\text { Endemic }\end{array}$ & $\begin{array}{l}\text { Chloramine } \\
\text { tablets with } \\
\text { hygiene } \\
\text { promotion }\end{array}$ & $\begin{array}{l}\text { Quantitative } \\
\text { Before/after: } 384 \\
\mathrm{HH}\end{array}$ & $\begin{array}{l}14 \% \text { reported use of tablets. } 26 \% \\
\text { Reported use of any HWT; } 14.5 \% \\
\text { boiling. } \\
14 \% \text { confirmed use (FCR } 0.3-0.6 \mathrm{mg} / \mathrm{L} \text { ) }\end{array}$ & $\begin{array}{l}\text { Low risk of bias } \\
\text { Methods, } \\
\text { sample } \\
\text { selection, and } \\
\text { limitations } \\
\text { clearly } \\
\text { described }\end{array}$ \\
\hline
\end{tabular}

HWT - chlorine-based products: liquid chlorine

\begin{tabular}{|c|c|c|c|c|c|}
\hline $\begin{array}{l}\text { Author (year) title } \\
\text { Type }\end{array}$ & Context & $\begin{array}{l}\text { Description } \\
\text { of activities }\end{array}$ & Evaluation & Key impacts & $\begin{array}{l}\text { Bias } \\
\text { Comments }\end{array}$ \\
\hline $\begin{array}{l}\text { Dunston (2001) } \\
\text { Collaboration, } \\
\text { cholera, and } \\
\text { cyclones: A project to } \\
\text { improve point-of-use } \\
\text { water quality in } \\
\text { Madagascar } \\
\text { Published }\end{array}$ & $\begin{array}{l}\text { Cholera } \\
\text { Madagascar } \\
\text { Outbreak }\end{array}$ & $\begin{array}{l}\text { Liquid chlorine } \\
\text { marketed to } \\
\text { community } \\
\text { (Safe Water } \\
\text { System (SwS) } \\
- \\
\text { WaterGuard®). } \\
\text { Jerry cans } \\
\text { available but } \\
\text { not distributed }\end{array}$ & $\begin{array}{l}\text { Quantitative } \\
\text { Before/After: } 375 \\
\mathrm{HH}-15 \\
\text { communities } \\
\text { stratified by } \\
\text { mobilization } \\
\text { strategy }\end{array}$ & $\begin{array}{l}19.7 \% \text { reported use (increased from } \\
8.4 \% \text { baseline, } 6 \text { months after } \\
\text { mobilization dropped to } 11.2 \% \text { ) } \\
\text { No confirmed use - FCR in } \mathrm{HH} \text { using } \\
\text { SwS } 0.23 \mathrm{mg} / \mathrm{L} \text { (median), compared to } \\
0.1 \mathrm{mg} / \mathrm{L} \text { in } \mathrm{HH} \text { not using ( } \mathrm{p}=0.005 \text { ) }\end{array}$ & $\begin{array}{l}\text { High risk of } \\
\text { bias } \\
\text { Selective } \\
\text { reporting, } \\
\text { incomplete } \\
\text { outcomes }\end{array}$ \\
\hline $\begin{array}{l}\text { Mong (2001) Impact } \\
\text { of Safe Water System } \\
\text { on Water Quality in } \\
\text { Cyclone-Affected } \\
\text { Communities in } \\
\text { Madagascar } \\
\text { Published }\end{array}$ & $\begin{array}{l}\text { Cholera } \\
\text { Madagascar } \\
\text { Outbreak }\end{array}$ & $\begin{array}{l}\text { Liquid chlorine } \\
\text { and } 5 \text { gallon } \\
\text { flexible jerry } \\
\text { can distributed } \\
\text { to } 11,700 \mathrm{HH} \\
\text { with some } \\
\text { education } \\
\text { about use }\end{array}$ & $\begin{array}{l}\text { Quantitative } \\
123 \mathrm{HH} \text { (random) }\end{array}$ & $\begin{array}{l}65 \% \text { reported use }(n=123) \text {; 'ever used' } \\
85 \% \text {; SwS already promoted in the } \\
\text { area } \\
45 \% \text { confirmed use }(n=40) \text { (FCR } \\
\geq 0.2 \mathrm{mg} / \mathrm{L}) \\
76 \% \text { report receiving jerry can; } 76 \% \\
\text { reported using }\end{array}$ & $\begin{array}{l}\text { High risk of } \\
\text { bias } \\
\text { Selective } \\
\text { reporting and } \\
\text { outcomes }\end{array}$ \\
\hline $\begin{array}{l}\text { Lantagne (2012) Use } \\
\text { of Household Water } \\
\text { Treatment and Safe } \\
\text { Storage Methods in } \\
\text { Acute Emergency } \\
\text { Response: Case } \\
\text { Study Nepal } \\
\text { Published }\end{array}$ & $\begin{array}{l}\text { Cholera } \\
\text { Nepal } \\
\text { Outbreak }\end{array}$ & $\begin{array}{l}\text { Local NGOs } \\
\text { using pre- } \\
\text { positioned } \\
\text { stock. } 1565 \mathrm{HH} \\
\text { - received } \\
\text { liquid chlorine } \\
\text { (WaterGuard®, } \\
\text { Piyush®) but } \\
\text { also } \\
\text { Aquatabs } ®\end{array}$ & $\begin{array}{l}\text { Quantitative } \\
\text { Cross-sectional: } \\
400 \mathrm{HH}\end{array}$ & $\begin{array}{l}\text { 22.2\% reported use (2 products: } \\
\text { WaterGuard®: } 6.3 \% \text { Piyush®: } 15.8 \% \text { ) } \\
\text { (Aquatabs®: } 8.3 \% \text { ) } \\
\text { 11.8\% confirmed Use (2 products: } \\
\text { WaterGuard®: } 3.5 \% \text {; Piyush®: } 8.3 \% \text { ) } \\
\text { (Aquatabs®: } 6.8 \% \text { ) (FCR } \geq 0.2 \mathrm{mg} / \mathrm{L} \text { ) }\end{array}$ & $\begin{array}{l}\text { Low risk of bias } \\
\text { Selection bias } \\
\text { not likely, clear } \\
\text { and consistent } \\
\text { reporting of } \\
\text { outcomes }\end{array}$ \\
\hline $\begin{array}{l}\text { ACF (2014) Projet } \\
\text { pilote de l'approche } \\
\text { de marché pour la } \\
\text { promotion du chlore } \\
\text { liquide } \\
\text { Grey literature }\end{array}$ & $\begin{array}{l}\text { Cholera } \\
\text { DRC } \\
\text { Endemic }\end{array}$ & $\begin{array}{l}\text { Promotion and } \\
\text { distribution of } \\
\text { liquid chlorine } \\
\text { with vouchers } \\
\text { to } 834 \mathrm{HH}\end{array}$ & $\begin{array}{l}\text { Quantitative } \\
\text { Cross-sectional: } \\
32 \mathrm{HH}\end{array}$ & $\begin{array}{l}\text { No reported use. Voucher redeemed } \\
\text { by } 88 \% \text { of } \mathrm{HH} \\
69 \% \text { confirmed use }(\mathrm{FCR} \geq 0.2 \mathrm{mg} / \mathrm{L} \text {; } \\
\text { Average } \mathrm{FCR} 0.5 \mathrm{mg} / \mathrm{L}) \\
97 \% \text { of } \mathrm{HH}(31 / 32) \text { reported being } \\
\text { satisfied with liquid chlorine as a HWT }\end{array}$ & $\begin{array}{l}\text { Medium risk of } \\
\text { bias } \\
\text { Potential } \\
\text { spillover and } \\
\text { selective } \\
\text { reporting }\end{array}$ \\
\hline
\end{tabular}




\section{HWT - chlorine-based products: PUR® Purifier of Water}

\begin{tabular}{|c|c|c|c|c|c|}
\hline $\begin{array}{l}\text { Author (year) title } \\
\text { Type }\end{array}$ & Context & $\begin{array}{l}\text { Description of } \\
\text { activities }\end{array}$ & Evaluation & Key impacts & $\begin{array}{l}\text { Bias } \\
\text { Comments }\end{array}$ \\
\hline $\begin{array}{l}\text { Doocy (2006) Point- } \\
\text { of-use water } \\
\text { treatment and } \\
\text { diarrhoea reduction in } \\
\text { the emergency } \\
\text { context: an } \\
\text { effectiveness trial in } \\
\text { Liberia } \\
\text { Published }\end{array}$ & $\begin{array}{l}\text { Cholera } \\
\text { Liberia } \\
\text { Endemic }\end{array}$ & $\begin{array}{l}\text { PUR® Purifier of } \\
\text { Water sachets } \\
\text { (weekly } \\
\text { distributions) with } \\
210 \mathrm{~L} \text { buckets } \\
\text { compared to HH } \\
\text { given just } \\
\text { buckets }\end{array}$ & $\begin{array}{l}\text { Quantitative } \\
200 \mathrm{HH} \\
\text { intervention and } \\
200 \mathrm{HH} \text { control }\end{array}$ & $\begin{array}{l}95.4 \% \text { confirmed use - "compliant" } \\
\text { with FCR and reported use } \\
\text { Health impact: Diarrhoea incidence } \\
\text { reduced by } 67 \% \text { (absolute risk } \\
\text { reduction (adjusted RR) } 0.33 ; 95 \% \mathrm{Cl} \\
0.30-0.37 \text { ); diarrhoea prevalence } \\
\text { reduced by } 77 \% \text { (adjusted RR } 0.23 \text {; } \\
95 \% \mathrm{Cl} 0.21-0.25 \text { ). Covered stored } \\
\text { water alone was also protective for } \\
\text { diarrhoea incidence (adjusted RR } 0.84 \text {; } \\
95 \% \mathrm{Cl} 0.82-0.86 \text { ) }\end{array}$ & $\begin{array}{l}\text { Medium risk of } \\
\text { bias } \\
\text { Weekly visits } \\
\text { for } 12 \text { weeks } \\
\text { prone to } \\
\text { courtesy bias; } \\
\text { rainy season } \\
\text { over - less } \\
\text { diarrhoea }\end{array}$ \\
\hline $\begin{array}{l}\text { Lantagne (2012) Use } \\
\text { of Household Water } \\
\text { Treatment and Safe } \\
\text { Storage Methods in } \\
\text { Acute Emergency } \\
\text { Response: Case } \\
\text { Study Kenya } \\
\text { Published }\end{array}$ & $\begin{array}{l}\text { Cholera } \\
\text { Kenya } \\
\text { Outbreak }\end{array}$ & $\begin{array}{l}\text { Pre-positioned } \\
\text { stock. Distribution } \\
\text { of Aquatabs }{ }^{\circledR} \\
\text { and PUR } ® \\
\text { Purifier of Water } \\
\text { in an NFI kit to } \\
5,592 \mathrm{HH}\end{array}$ & $\begin{array}{l}\text { Quantitative } \\
\text { Cross-sectional: } \\
409 \mathrm{HH}\end{array}$ & $\begin{array}{l}\text { 12.7\% reported use (PUR@ Purifier of } \\
\text { Water: } 5.9 \% \text { ) } \\
7.9 \% \text { confirmed use (PUR: } 3.7 \% \text { ) } \\
\text { (FCR } \geq 0.2 \mathrm{mg} / \mathrm{L} \text { ) } \\
5.3 \% \text { effective use }<1 \text { CFU } 100 \mathrm{~mL} \\
\text { (PUR: } 2.3 \% \text { ) }\end{array}$ & $\begin{array}{l}\text { Low risk of bias } \\
\text { Selection bias } \\
\text { not likely, } \\
\text { consistent } \\
\text { reporting of } \\
\text { outcomes }\end{array}$ \\
\hline $\begin{array}{l}\text { ACF (2014) Hygiene } \\
\text { Kits Post Distribution } \\
\text { Monitoring Report } \\
\text { Grey literature }\end{array}$ & $\begin{array}{l}\text { Cholera } \\
\text { South } \\
\text { Sudan } \\
\text { Outbreak }\end{array}$ & $\begin{array}{l}\text { Aquatabs } ® \\
\text { distributed in NFI } \\
\text { kits to } 7,348 \mathrm{HH} \text {. } \\
\text { Kit also included: } \\
\text { bucket, PUR® } \\
\text { Purifier of Water } \\
\text { packets and filter } \\
\text { cloth }\end{array}$ & $\begin{array}{l}\text { Quantitative } \\
\text { Cluster cross- } \\
\text { sectional: } 351 \mathrm{HH}\end{array}$ & $\begin{array}{l}87 \% \text { confirmed use }(>0.1 \mathrm{mg} / \mathrm{L}) \text { in } \mathrm{HH} \\
\text { with Aquatabs }(6 \% \text { of } \mathrm{HH} \text { FCR } \\
>0.5 \mathrm{mg} / \mathrm{L}) \\
>90 \% \text { of } \mathrm{HH} \text { had } \mathrm{FCR} \text { in Juba (range } \\
83-100 \%) \\
78 \% \text { of } \mathrm{HH} \text { could demonstrate correct } \\
\text { use of PUR® } \\
\mathrm{HH} \text { without FCR said they get water } \\
\text { from a treated tanker, or are saving the } \\
\text { Aquatabs } \AA \text { for when cholera outbreaks } \\
\text { again }\end{array}$ & $\begin{array}{l}\text { High risk of } \\
\text { bias } \\
\text { Inconsistent } \\
\text { reporting, } \\
\text { spillover effects } \\
\text { likely }\end{array}$ \\
\hline
\end{tabular}

HWT - other products: filtrations, SODIS, safe storage

\begin{tabular}{|c|c|c|c|c|c|}
\hline $\begin{array}{l}\text { Author (year) title } \\
\text { Type }\end{array}$ & Context & $\begin{array}{l}\text { Description of } \\
\text { activities }\end{array}$ & Evaluation & Key impacts & $\begin{array}{l}\text { Bias } \\
\text { Comments }\end{array}$ \\
\hline $\begin{array}{l}\text { Conroy (2001) Solar } \\
\text { disinfection of } \\
\text { drinking water } \\
\text { protects against } \\
\text { cholera in children } \\
\text { under } 6 \text { years of age } \\
\text { Published }\end{array}$ & $\begin{array}{l}\text { Cholera } \\
\text { Kenya } \\
\text { Outbreak }\end{array}$ & $\begin{array}{l}1.5 \mathrm{~L} \text { clear plastic } \\
\text { bottle distributed } \\
\text { with instructions } \\
\text { (SODIS project) - } \\
\text { targeted children } \\
\text { under }<5\end{array}$ & $\begin{array}{l}\text { Quantitative } \\
67 \mathrm{HH} \text { intervention } \\
\text { and } 64 \text { control; } \mathrm{HH} \\
\text { had child under } 5 \\
\text { years for original } \\
\text { study then monitored } \\
\text { a year after (case- } \\
\text { control out of an } \\
\text { RCT) }\end{array}$ & $\begin{array}{l}\text { No reported use. (67/131 used } \\
\text { SODIS) } \\
\text { Health impact: Self-reported } \\
\text { cases of cholera: }<6 \text { yr: (RR } \\
0.12 ; 0.02-0.65 ; p=0.014) ; 6-15 \\
\text { yr: (RR } 1.09 ; 0.58-2.05) ; \text { Adults: } \\
\text { (RR } 1.2 ; 0.59-2.5)\end{array}$ & $\begin{array}{l}\text { High risk of } \\
\text { bias } \\
\text { Inconsistent } \\
\text { results, unclear } \\
\text { intervention } \\
\text { impact }\end{array}$ \\
\hline $\begin{array}{l}\text { Colwell (2003) } \\
\text { Reduction of cholera } \\
\text { in Bangladeshi } \\
\text { villages by simple } \\
\text { filtration } \\
\text { Published }\end{array}$ & $\begin{array}{l}\text { Cholera } \\
\text { Bangladesh } \\
\text { Endemic }\end{array}$ & 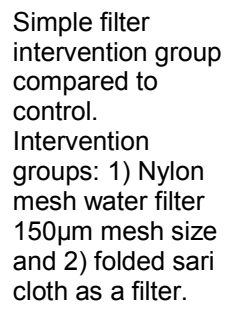 & $\begin{array}{l}\text { Quantitative } \\
65 \text { villages: } 27 \\
\text { villages using Sari; } \\
25 \text { villages using } \\
\text { filter screen; } 13 \\
\text { villages control. } \\
\sim 44,000 \text { in each } \\
\text { group. }\end{array}$ & $\begin{array}{l}90 \% \text { reported use of filters } \\
\text { Health impact: } 38 \% \text { reduction in } \\
\text { cholera cases by filter use, } \\
\text { hospital confirmed cases. (Nylon } \\
\text { filter: control OR: } 0.59 ; p<0.05) \\
\text { (Cloth filter: control OR: } 0.52 \\
\text { Sari ( } 8 \text { folds); } p<0.05 \text { ) }\end{array}$ & $\begin{array}{l}\text { Low risk of bias } \\
\text { Pilot } \\
\text { intervention } \\
\text { had strong } \\
\text { consistent } \\
\text { results, but } \\
\text { increased for } \\
\text { power }\end{array}$ \\
\hline $\begin{array}{l}\text { Huq (2010) Simple } \\
\text { sari cloth filtration of } \\
\text { water is sustainable } \\
\text { and continues to } \\
\text { protect villagers from } \\
\text { cholera in Matlab, } \\
\text { Bangladesh } \\
\text { Published }\end{array}$ & $\begin{array}{l}\text { Cholera } \\
\text { Bangladesh } \\
\text { Endemic }\end{array}$ & $\begin{array}{l}5 \text { years after } \\
\text { Colwell, revisit } \\
\text { same HH to see } \\
\text { use of HWT }\end{array}$ & $\begin{array}{l}\text { Quantitative } \\
7,233 \mathrm{HH}, 5 \text { years } \\
\text { after Colwell (2003); } \\
2,251 \text { nylon filter, } \\
\text { 2,556 cloth group, } \\
\text { and } 2,426 \text { control } \\
\text { group intervention }\end{array}$ & $\begin{array}{l}31 \% \text { reported use of a filter } \\
(2,207 \text { of } 7,233 \mathrm{HH}) \text {; Sari group } \\
(35 \%) \text {, nylon filter }(26 \%) \text {, control } \\
\text { group }(23 \%) \\
\text { Confirmed use } 38 \% \text { of reported } \\
\text { rates }(19 / 50) \text { (through } 11 \text { hour } \\
\text { observation period) }\end{array}$ & $\begin{array}{l}\text { Medium risk of } \\
\text { bias } \\
\text { Spillover } \\
\text { effects likely }\end{array}$ \\
\hline
\end{tabular}




\begin{tabular}{|c|c|c|c|c|c|}
\hline $\begin{array}{l}\text { Author (year) title } \\
\text { Type }\end{array}$ & Context & $\begin{array}{l}\text { Description of } \\
\text { activities }\end{array}$ & Evaluation & Key impacts & $\begin{array}{l}\text { Bias } \\
\text { Comments }\end{array}$ \\
\hline $\begin{array}{l}\text { Roberts (2001) } \\
\text { Keeping clean water } \\
\text { clean in a Malawi } \\
\text { refugee camp: a } \\
\text { randomized } \\
\text { intervention trial } \\
\text { Published }\end{array}$ & $\begin{array}{l}\text { Cholera } \\
\text { Malawi } \\
\text { Endemic }\end{array}$ & $\begin{array}{l}\text { Improved bucket } \\
\text { distribution to } \\
\text { intervention group, } \\
\text { only told not to put } \\
\text { hands in the } \\
\text { buckets. } \\
\text { Compared to } \\
\text { standard buckets }\end{array}$ & $\begin{array}{l}\text { Quantitative } \\
\text { RCT: } 100 \\
\text { intervention } \mathrm{HH} \text { and } \\
300 \text { control } \mathrm{HH}\end{array}$ & $\begin{array}{l}\text { No reported use. } \\
\text { Health impact: } 8.4 \% \text { lower } \\
\text { diarrhoea attack rate with } \\
\text { improved buckets ( } p=0.26 \text { ); } \\
\text { children }<5,31.1 \% \text { lower } \\
\text { diarrhoea attack rate with } \\
\text { improved buckets in children } \\
\text { ( } p=0.06) \\
\text { Non-health impact: } 53.3 \% \text { lower } \\
(69 \% \text { lower with geometric } \\
\text { mean) faecal coliforms in } \\
\text { improved vs. control buckets } \\
\text { over several hours (measured at } \\
6 \text { time steps) } n=604\end{array}$ & $\begin{array}{l}\text { Low risk of bias } \\
\text { HH visited } 2 \mathrm{x} \\
\text { per week for } \\
\text { diarrhoea } \\
\text { rates; loss to } \\
\text { follow-up } \\
\text { significantly } \\
\text { different }\end{array}$ \\
\hline $\begin{array}{l}\text { Einarsdbttir (2001) } \\
\text { Health Education and } \\
\text { Cholera in Rural } \\
\text { Guinea-Bissau } \\
\text { Published }\end{array}$ & $\begin{array}{l}\text { Cholera } \\
\text { Guinea- } \\
\text { Bissau } \\
\text { Endemic }\end{array}$ & $\begin{array}{l}\text { Hygiene promotion } \\
\text { to support treating } \\
\text { water (and other } \\
\text { hygiene practices). } \\
\text { Radio, TV, health } \\
\text { staff, poster, word } \\
\text { of mouth, song, } \\
\text { theatre group }\end{array}$ & $\begin{array}{l}\text { Quantitative } \\
53 \mathrm{HH} \text { (random) }\end{array}$ & $\begin{array}{l}66 \% \text { reported use with lemon to } \\
\text { treat water; } 40 \% \text { reported boiling } \\
\text { water; no one reported only } \\
\text { drinking treated (boiled /lemon) } \\
\text { water. Not consistent use of } \\
\text { treated water }\end{array}$ & $\begin{array}{l}\text { High risk of } \\
\text { bias } \\
\text { Small sample } \\
\text { size, open- } \\
\text { ended } \\
\text { questions, self- } \\
\text { reported results }\end{array}$ \\
\hline
\end{tabular}

\section{SANITATION}

\section{Community-driven sanitation}

\begin{tabular}{|c|c|c|c|c|c|}
\hline $\begin{array}{l}\text { Author (year) title } \\
\text { Type }\end{array}$ & Context & $\begin{array}{l}\text { Description of } \\
\text { activities }\end{array}$ & Evaluation & Key impacts & $\begin{array}{l}\text { Bias } \\
\text { Comments }\end{array}$ \\
\hline $\begin{array}{l}\text { Meyer Capps (2015) } \\
\text { Open Defecation } \\
\text { Status, Community- } \\
\text { Led Total Sanitation } \\
\text { and Ebola Virus } \\
\text { Disease (EVD) in } \\
\text { Voinjama and } \\
\text { Kolahun Health } \\
\text { Districts, Lofa County, } \\
\text { Liberia (2014) } \\
\text { Grey literature }\end{array}$ & $\begin{array}{l}\text { Ebola } \\
\text { Liberia } \\
\text { Outbreak }\end{array}$ & $\begin{array}{l}\text { CLTS project } \\
\text { (running for } 5 \text { years } \\
\text { - carried on } \\
\text { through Ebola } \\
\text { outbreak) in } 6,865 \\
\text { HH }\end{array}$ & $\begin{array}{l}\text { Quantitative } \\
\text { Mixed-methods; } \\
\text { Matched controls: } \\
239 \text { Project } \mathrm{HH} \text { : } \\
312 \text { non-Project } \\
\text { HH, } 16 \text { FGD, KII }\end{array}$ & $\begin{array}{l}\text { HH in CLTS communities } 17 \\
\text { times less likely to have cases of } \\
\text { Ebola than non-CLTS } \\
\text { communities (OR=0.06, } \\
\mathrm{p}<0.001 \text { ) } \\
\text { Beneficiaries trusted: } 1 \text { ) Health } \\
\text { workers, } 2 \text { ) radio, then } 3 \text { ) NGOs } \\
\text { for sources of info by both CLTS } \\
\text { and non-CLTS communities }\end{array}$ & $\begin{array}{l}\text { Medium risk of } \\
\text { bias } \\
\text { Spillover } \\
\text { effects unclear }\end{array}$ \\
\hline $\begin{array}{l}\text { Waterkeyn (2005) } \\
\text { Rapid sanitation } \\
\text { uptake in the } \\
\text { internally displaced } \\
\text { people camps of } \\
\text { northern Uganda } \\
\text { through community } \\
\text { health clubs } \\
\text { Published }\end{array}$ & $\begin{array}{l}\text { Cholera } \\
\text { Uganda } \\
\text { Outbreak }\end{array}$ & $\begin{array}{l}\text { Community } \\
\text { mobilization } \\
\text { through community } \\
\text { health club and } \\
\text { PHAST } \\
\text { approaches: } \\
\text { community trainers, } \\
\text { drama } \\
\text { presentations, } 20 \\
\text { hygiene topics, } \\
\text { delivered in groups, } \\
\text { peer pressure to } \\
\text { keep them. } \\
\text { Certificate if } \\
\text { attended } 20 \\
\text { sessions. } \\
\text { Community } \\
\text { provided own } \\
\text { materials but would } \\
\text { receive a concrete } \\
\text { 'sanplat' (latrine } \\
\text { floor) }\end{array}$ & $\begin{array}{l}\text { Field commentary } \\
\text { Case study }\end{array}$ & $\begin{array}{l}\text { Group cohesion and peer } \\
\text { pressure adjusted hygiene } \\
\text { behaviour and improve hygiene } \\
\text { practices } \\
\text { Motivation of }>15,000 \\
\text { beneficiaries; built } 8,500 \\
\text { latrines, } 6,000 \text { bath shelters, } \\
3,400 \text { drying racks, and } 1,550 \\
\text { handwashing stations in a } 4 \\
\text { month timeframe } \\
\text { Rapid, scalable, and cost- } \\
\text { effective }\end{array}$ & $\begin{array}{l}\text { High risk of } \\
\text { bias } \\
\text { Case study } \\
\text { description }\end{array}$ \\
\hline
\end{tabular}


HYGIENE

Hygiene education

\begin{tabular}{|c|c|c|c|c|c|}
\hline $\begin{array}{l}\text { Author (year) title } \\
\text { Type }\end{array}$ & Context & $\begin{array}{l}\text { Description of } \\
\text { activities }\end{array}$ & Evaluation & Key impacts & $\begin{array}{l}\text { Bias } \\
\text { Comments }\end{array}$ \\
\hline $\begin{array}{l}\text { Einarsdbttir (2001) } \\
\text { Health Education and } \\
\text { Cholera in Rural } \\
\text { Guinea-Bissau } \\
\text { Published }\end{array}$ & $\begin{array}{l}\text { Cholera } \\
\text { Guinea- } \\
\text { Bissau } \\
\text { Endemic }\end{array}$ & $\begin{array}{l}\text { Hygiene promotion } \\
\text { to support treating } \\
\text { water (and other } \\
\text { hygiene practices). } \\
\text { Radio, TV, health } \\
\text { staff, poster, word- } \\
\text { of-mouth, song, } \\
\text { theatre group }\end{array}$ & $\begin{array}{l}\text { Quantitative } \\
53 \mathrm{HH} \text { (Random) }\end{array}$ & $\begin{array}{l}\text { Radio and word-of-mouth were } \\
\text { most received and best understood } \\
66 \% \text { reported use with lemon to } \\
\text { treat water; } 40 \% \text { reported boiling } \\
\text { water boiling water; no one reported } \\
\text { only drinking treated (boiled/lemon) } \\
\text { water. Not consistent use of treated } \\
\text { water }\end{array}$ & $\begin{array}{l}\text { High risk of bias } \\
\text { Small sample } \\
\text { size, open- } \\
\text { ended } \\
\text { questions, self- } \\
\text { reported results }\end{array}$ \\
\hline $\begin{array}{l}\text { Meyer Capps (2015) } \\
\text { Open Defecation } \\
\text { Status, Community- } \\
\text { Led Total Sanitation } \\
\text { and Ebola Virus } \\
\text { Disease (EVD) in } \\
\text { Voinjama and Kolahun } \\
\text { Health Districts, Lofa } \\
\text { County, Liberia (2014) } \\
\text { Grey literature }\end{array}$ & $\begin{array}{l}\text { Ebola } \\
\text { Liberia } \\
\text { Outbreak }\end{array}$ & $\begin{array}{l}\text { CLTS project } \\
\text { (running for } 5 \text { years } \\
\text { - carried on through } \\
\text { Ebola outbreak) in } \\
6,865 \mathrm{HH}\end{array}$ & $\begin{array}{l}\text { Quantitative } \\
\text { Matched controls. } \\
239 \text { Project } \mathrm{HH} \text { : } \\
312 \text { non-Project } \\
\text { HH }\end{array}$ & $\begin{array}{l}\text { Beneficiaries trusted: } 1 \text { ) Health } \\
\text { workers, 2) radio, then } 3 \text { ) NGOs for } \\
\text { sources of information by both } \\
\text { CLTS and non-CLTS communities } \\
\text { HH in CLTS communities } 17 \text { times } \\
\text { less likely to have cases of Ebola } \\
\text { than non-CLTS communities } \\
(O R=0.06, p<0.001)\end{array}$ & $\begin{array}{l}\text { Medium risk of } \\
\text { bias } \\
\text { Spillover effects } \\
\text { likely }\end{array}$ \\
\hline $\begin{array}{l}\text { Williams (2015) } \\
\text { Perceptions of health } \\
\text { Communication, } \\
\text { Water Treatment and } \\
\text { Sanitation in Artibonite } \\
\text { Department, Haiti, } \\
\text { March-April } 2012 \\
\text { Published }\end{array}$ & $\begin{array}{l}\text { Cholera } \\
\text { Haiti } \\
\text { Outbreak }\end{array}$ & $\begin{array}{l}\text { Evaluation of WASH } \\
\text { preferences in } \\
\text { regional cholera } \\
\text { response }\end{array}$ & $\begin{array}{l}\text { Qualitative } \\
18 \text { FGD }\end{array}$ & $\begin{array}{l}\text { Most valuable source of information } \\
\text { - community health worker (CHW) } \\
\text { and megaphone going house to } \\
\text { house was the best way to reach } \\
\text { the communities } \\
\text { Most 'trusted' vender of HWT } \\
\text { products - pharmacies } \\
\text { Increase in handwashing as a result } \\
\text { from messaging } \\
\text { Perceived reduction in diarrhoea }\end{array}$ & $\begin{array}{l}\text { Medium risk of } \\
\text { bias } \\
\text { Inconsistent } \\
\text { language } \\
\text { definitions, self- } \\
\text { reporting }\end{array}$ \\
\hline $\begin{array}{l}\text { Date (2013) } \\
\text { Evaluation of a Rapid } \\
\text { Cholera Response } \\
\text { Activity - Nyanza } \\
\text { Province, Kenya, } 2008 \\
\text { Published }\end{array}$ & $\begin{array}{l}\text { Cholera } \\
\text { Kenya } \\
\text { Endemic }\end{array}$ & $\begin{array}{l}\text { Distribution of HWT } \\
\text { and hygiene kits } \\
\text { (not described); } \\
\text { environmental } \\
\text { investigations, } \\
\text { cholera case } \\
\text { management }\end{array}$ & $\begin{array}{l}\text { Quantitative } \\
\text { Cross-sectional: } \\
358 \text { intervention } \\
\mathrm{HH} \text { and } 365 \\
\text { control HH }\end{array}$ & $\begin{array}{l}\text { Social contacts (friends, family, and } \\
\text { neighbours), which suggests that } \\
\text { social networks can be a valuable } \\
\text { resource } \\
\text { No reported use (Reported any } \\
\text { water treatment: Intervention: } \\
\text { Control } 56 \% \text { : } 37 \% \text {; p<0.001) } \\
\text { No confirmed use ('Detectable' } \\
\text { FCR } 17 \% \text { in intervention and } 14 \% \\
\text { in control groups; NS) }\end{array}$ & $\begin{array}{l}\text { High risk of bias } \\
\text { Intervention } \\
\text { overlap, } \\
\text { intervention } \\
\text { loosely } \\
\text { described, } \\
\text { convenience } \\
\text { sample, } 3 \\
\text { month recall } \\
\text { time }\end{array}$ \\
\hline $\begin{array}{l}\text { WHO (no date) } \\
\text { guidance on } \\
\text { communication with } \\
\text { respect to safe } \\
\text { drinking water and } \\
\text { household hygiene } \\
\text { literature review, } \\
\text { interviews and case } \\
\text { studies; case study - } \\
\text { South Africa } \\
\text { Grey Literature }\end{array}$ & $\begin{array}{l}\text { Cholera } \\
\text { South Africa } \\
\text { Outbreak }\end{array}$ & $\begin{array}{l}\text { Hygiene campaign: } \\
\text { Messages: Water } \\
\text { storage, personal } \\
\text { hygiene, safe refuse } \\
\text { disposal, food } \\
\text { handling, use of } \\
\text { HWT } \\
\text { Mode: health } \\
\text { workers, schools, } \\
\text { religious leaders; } \\
\text { some religious } \\
\text { services use to } \\
\text { recruit volunteers }\end{array}$ & $\begin{array}{l}\text { Field commentary } \\
\text { Case study }\end{array}$ & $\begin{array}{l}\text { Red Cross (working in specific } \\
\text { areas) observed a sharp decline in } \\
\text { mortality rates following education } \\
\text { progamme. } \\
\text { Hygiene messages were known } \\
\text { beforehand }\end{array}$ & $\begin{array}{l}\text { High risk of bias } \\
\text { Case study } \\
\text { commentary }\end{array}$ \\
\hline $\begin{array}{l}\text { WHO (No Date) } \\
\text { Guidance on } \\
\text { communication with } \\
\text { respect to safe } \\
\text { drinking water and } \\
\text { household hygiene } \\
\text { Literature review, } \\
\text { interviews and case } \\
\text { studies; case study - } \\
\text { Zimbabwe } \\
\text { Grey literature }\end{array}$ & $\begin{array}{l}\text { Cholera } \\
\text { Zimbabwe } \\
\text { Outbreak }\end{array}$ & $\begin{array}{l}\text { Cholera prevention, } \\
\text { control, food prep, } \\
\text { hand washing, use } \\
\text { of HWT } \\
\text { (tablets/sachets) } \\
\text { Mode: T-shirts and } \\
\text { dramas used, } \\
310,000 \text { flyers, } \\
14,000 \text { posters in } 3 \\
\text { languages } \\
\text { distributed to } \\
250,000 \text { people }\end{array}$ & $\begin{array}{l}\text { Field commentary } \\
\text { Case study }\end{array}$ & $\begin{array}{l}\text { Change in behaviour - not } \\
\text { attending funerals, reducing } \\
\text { physical contact (hugs, shaking } \\
\text { hands) } \\
\text { Response built on existing } \\
\text { organizations } \\
\text { Unwillingness to drink chlorinated } \\
\text { water } \\
\text { Lack of resources and worthless } \\
\text { currency }\end{array}$ & $\begin{array}{l}\text { High risk of bias } \\
\text { Case study } \\
\text { commentary }\end{array}$ \\
\hline
\end{tabular}




\begin{tabular}{|c|c|c|c|c|c|}
\hline $\begin{array}{l}\text { Author (year) title } \\
\text { Type }\end{array}$ & Context & $\begin{array}{l}\text { Description of } \\
\text { activities }\end{array}$ & Evaluation & Key impacts & $\begin{array}{l}\text { Bias } \\
\text { Comments }\end{array}$ \\
\hline $\begin{array}{l}\text { ACF - Matemo (2014) } \\
\text { Use Of H2S To } \\
\text { Support Hygiene } \\
\text { Promotion } \\
\text { Grey literature }\end{array}$ & $\begin{array}{l}\text { Cholera/ } \\
\text { hepatitis } \\
\text { Kenya } \\
\text { Spike in } \\
\text { cases }\end{array}$ & $\begin{array}{l}\mathrm{H}_{2} \mathrm{~S} \text { used as part of } \\
\text { hygiene promotion }\end{array}$ & $\begin{array}{l}\text { Field commentary } \\
2,820 \mathrm{HH} \text { tests - } \\
\text { methods unclear }\end{array}$ & $\begin{array}{l}\text { Use of } \mathrm{H}_{2} \mathrm{~S} \text { used a visual aid to } \\
\text { assist hygiene messaging as well } \\
\text { as test water samples. } \\
\text { Proof to community that 'clear } \\
\text { doesn't mean safe' }\end{array}$ & $\begin{array}{l}\text { High risk of bias } \\
\text { Unclear } \\
\text { methods and } \\
\text { reporting }\end{array}$ \\
\hline $\begin{array}{l}\text { Wall (2011) Ann Kite } \\
\text { Yo Pale (let them } \\
\text { speak) Best Practice } \\
\text { and Lessons Learned } \\
\text { in Communication with } \\
\text { Disaster Affected } \\
\text { Communities: Haiti } \\
2010 \\
\text { Grey literature }\end{array}$ & $\begin{array}{l}\text { Cholera } \\
\text { Haiti } \\
\text { Outbreak }\end{array}$ & $\begin{array}{l}\text { Various } \\
\text { communication } \\
\text { strategies from } \\
\text { many organizations }\end{array}$ & $\begin{array}{l}\text { Qualitative } \\
15 \text { FGD, KII (not } \\
\text { described) }\end{array}$ & $\begin{array}{l}\text { Communication was effective at } \\
\text { improving trust, mitigating conflict, } \\
\text { developing relationships, and } \\
\text { gaining insights to community } \\
\text { perceptions and values } \\
\text { 2-way communication was key - } \\
\text { asking a question, sharing stories, } \\
\text { discuss an issue (face-to-face was } \\
\text { key); technical and medical } \\
\text { messages did not address fears } \\
\text { and perceptions of the disease } \\
\text { Cholera treatment centres were } \\
\text { initially rejected due to fears about } \\
\text { the origin and response to the } \\
\text { disease } \\
\text { The assessments of overall effect } \\
\text { on communication efforts on } \\
\text { cholera, as "too many organizations } \\
\text { were involved and too many } \\
\text { techniques used" (p. 28) }\end{array}$ & $\begin{array}{l}\text { Medium risk of } \\
\text { bias } \\
\text { Unclear } \\
\text { methodology } \\
\text { and selective } \\
\text { reporting }\end{array}$ \\
\hline $\begin{array}{l}\text { Contzen-Mosler } \\
\text { (2013) Impact of } \\
\text { different promotional } \\
\text { channels on } \\
\text { handwashing } \\
\text { behaviour in an } \\
\text { emergency context: } \\
\text { Haiti post-earthquake } \\
\text { public health } \\
\text { promotions and } \\
\text { cholera response } \\
\text { Published }\end{array}$ & $\begin{array}{l}\text { Cholera } \\
\text { Haiti } \\
\text { Outbreak }\end{array}$ & $\begin{array}{l}\text { Various } \\
\text { communication } \\
\text { strategies from } \\
\text { many organizations }\end{array}$ & $\begin{array}{l}\text { Quantitative } \\
811 \mathrm{HH} \text { across } \\
\text { several regions }\end{array}$ & $\begin{array}{l}\text { For both faeces and food related } \\
\text { handwashing, the most effective } \\
\text { were material distributions with } \\
\text { demonstrations, and radio spots } \\
\text { Spontaneous/unplanned } \\
\text { promotions by friends and } \\
\text { neighbours also influential } \\
\text { For food related handwashing, } \\
\text { community clubs and theatres were } \\
\text { also relevant } \\
\text { Better targeting of messages could } \\
\text { be done - washing prevents } \\
\text { diarrhoea; severity of cholera } \\
\text { Focus groups, hygiene days, and } \\
\text { stickers/posters/paintings were } \\
\text { rated at less likeable, less } \\
\text { convincing, and less trustworthy } \\
\text { than other methods }\end{array}$ & $\begin{array}{l}\text { Medium risk of } \\
\text { bias } \\
\text { Large sample } \\
\text { size, but } \\
\text { possibility of } \\
\text { courtesy bias }\end{array}$ \\
\hline
\end{tabular}

\section{Social mobilization}

\begin{tabular}{|c|c|c|c|c|c|}
\hline $\begin{array}{l}\text { Author (year) title } \\
\text { Type }\end{array}$ & Context & Description of activities & Evaluation & Key impacts & $\begin{array}{l}\text { Bias } \\
\text { Comments }\end{array}$ \\
\hline $\begin{array}{l}\text { Meyer Capps (2015) } \\
\text { Open Defecation } \\
\text { Status, Community- } \\
\text { Led Total Sanitation } \\
\text { and Ebola Virus } \\
\text { Disease (EVD) in } \\
\text { Voinjama and Kolahun } \\
\text { Health Districts, Lofa } \\
\text { County, Liberia (2014) } \\
\text { Grey literature }\end{array}$ & $\begin{array}{l}\text { Ebola } \\
\text { Liberia } \\
\text { Outbreak }\end{array}$ & $\begin{array}{l}\text { CLTS project (running for } \\
5 \text { years - carried on } \\
\text { through Ebola outbreak) } \\
\text { in } 6,865 \mathrm{HH}\end{array}$ & $\begin{array}{l}\text { Quantitative } \\
\text { Matched } \\
\text { controls. } 239 \\
\text { Project HH: } \\
312 \text { non- } \\
\text { Project HH }\end{array}$ & $\begin{array}{l}\text { HH in CLTS communities } 17 \text { times } \\
\text { less likely to have cases of Ebola } \\
\text { than non-CLTS communities } \\
(O R=0.06, p<0.001) \\
\text { Beneficiaries trusted: } 1 \text { ) Health } \\
\text { workers, } 2 \text { ) radio, then } 3 \text { ) NGOs for } \\
\text { sources of info by both CLTS and } \\
\text { non-CLTS communities }\end{array}$ & $\begin{array}{l}\text { Medium risk of } \\
\text { bias } \\
\text { Spillover effects } \\
\text { likely }\end{array}$ \\
\hline $\begin{array}{l}\text { Waterkeyn (2005) } \\
\text { Rapid sanitation } \\
\text { uptake in the } \\
\text { internally displaced } \\
\text { people camps of } \\
\text { northern Uganda } \\
\text { through community } \\
\text { health clubs } \\
\text { Published }\end{array}$ & $\begin{array}{l}\text { Cholera } \\
\text { Uganda } \\
\text { Outbreak }\end{array}$ & $\begin{array}{l}\text { Community mobilization } \\
\text { through community } \\
\text { health club and PHAST } \\
\text { approaches: community } \\
\text { trainers, drama } \\
\text { presentations, } 20 \\
\text { hygiene topics, delivered } \\
\text { in groups, peer pressure } \\
\text { to keep them. Certificate } \\
\text { if attended } 20 \text { sessions. } \\
\text { Community provided } \\
\text { own materials but would } \\
\text { receive a concrete } \\
\text { 'sanplat' (latrine floor) }\end{array}$ & $\begin{array}{l}\text { Field } \\
\text { commentary } \\
\text { Case study }\end{array}$ & $\begin{array}{l}\text { Group cohesion and peer pressure } \\
\text { adjusted hygiene behaviour and } \\
\text { improve hygiene practices } \\
\text { Motivation of }>15,000 \\
\text { beneficiaries; built } 8,500 \text { latrines, } \\
6,000 \text { bath shelters, } 3,400 \text { drying } \\
\text { racks, and } 1,550 \text { handwashing } \\
\text { stations in a } 4 \text { month timeframe } \\
\text { Rapid, scalable, and cost-effective }\end{array}$ & $\begin{array}{l}\text { High risk of } \\
\text { bias } \\
\text { Case study } \\
\text { description }\end{array}$ \\
\hline
\end{tabular}




\begin{tabular}{|c|c|c|c|c|c|}
\hline $\begin{array}{l}\text { Author (year) title } \\
\text { Type }\end{array}$ & Context & Description of activities & Evaluation & Key impacts & $\begin{array}{l}\text { Bias } \\
\text { Comments }\end{array}$ \\
\hline $\begin{array}{l}\text { ACF (2015) Trigger } \\
\text { Behavioural Change } \\
\text { to strengthen } \\
\text { community's resilience } \\
\text { to Ebola Outbreaks } \\
\text { Grey literature }\end{array}$ & $\begin{array}{l}\text { Ebola } \\
\text { Sierra Leone } \\
\text { Outbreak }\end{array}$ & $\begin{array}{l}\text { Community Led Ebola } \\
\text { Management and } \\
\text { Eradication (CLEME), as } \\
\text { modified CLTS approach } \\
\text { with community driven } \\
\text { action. ACF also involved } \\
\text { in other aspects of the } \\
\text { response }\end{array}$ & $\begin{array}{l}\text { Field } \\
\text { commentary } \\
\text { Case study }\end{array}$ & $\begin{array}{l}\text { CLEME approach and 'triggering' } \\
\text { deemed successful in many } \\
\text { aspects: } 80 \% \text { of communities } \\
\text { planned isolation rooms; tippy tap } \\
\text { handwashing widely promoted; and } \\
\text { community ownership and trust } \\
\text { were shown to be very important } \\
\text { project results } \\
\text { Time, staff requirements, and } \\
\text { prerequisites limit wider applicability }\end{array}$ & $\begin{array}{l}\text { High risk of bias } \\
\text { Case study } \\
\text { description }\end{array}$ \\
\hline $\begin{array}{l}\text { IFRC - Rees-Gildea } \\
\text { (2013) Sierra Leone } \\
\text { Cholera ERU } \\
\text { Operation Review } \\
\text { Grey literature }\end{array}$ & $\begin{array}{l}\text { Cholera } \\
\text { Sierra Leone } \\
\text { Outbreak }\end{array}$ & $\begin{array}{l}\text { Sensitisation progamme } \\
\text { to } 350,000 \\
\text { Mode: radio, texts, } \\
\text { cinema progamme, } \\
\text { community volunteers, } \\
\text { school club progamme } \\
\text { Messages: 'key cholera } \\
\text { messages' } \\
419 \text { oral rehydration } \\
\text { points with ORS; } 500 \\
\text { wind up radios }\end{array}$ & $\begin{array}{l}\text { Field } \\
\text { commentary } \\
\text { Case study } \\
\text { (limited } \\
\text { evaluation) }\end{array}$ & $\begin{array}{l}\text { Decrease in CFR deemed to be } \\
\text { more influenced by social } \\
\text { mobilization promoting early } \\
\text { presentation and access to ORP } \\
\text { (mobilization more important that } \\
\text { case management) } \\
\text { Scalable networks with long- } \\
\text { running progammes } \\
\text { Not cost effective - planned for } \\
\text { worst case scenario (over staffed } \\
\text { with emergency and development } \\
\text { programming running } \\
\text { simultaneously) }\end{array}$ & $\begin{array}{l}\text { High risk of bias } \\
\text { Organization } \\
\text { review; case } \\
\text { study } \\
\text { commentary }\end{array}$ \\
\hline $\begin{array}{l}\text { IWSD - Neseni (2009) } \\
\text { Evaluation of the } \\
\text { WASH Response to } \\
\text { the 2008-2009 } \\
\text { Zimbabwe Cholera } \\
\text { Epidemic and } \\
\text { Preparedness } \\
\text { Planning for Future } \\
\text { Outbreaks } \\
\text { Grey literature }\end{array}$ & $\begin{array}{l}\text { Cholera } \\
\text { Zimbabwe } \\
\text { Outbreak }\end{array}$ & $\begin{array}{l}\text { Water trucking, drilling } \\
\text { boreholes, rehabilitation } \\
\text { of wells, HWT, water } \\
\text { quality monitoring } \\
\text { Latrine construction was } \\
\text { limited, rehab of latrines, } \\
\text { sewer decongestion, } \\
\text { rehab sewer pipes } \\
\text { Hygiene: door to door, } \\
\text { dramas, traveller } \\
\text { information, print and } \\
\text { electronic media, } \\
\text { 'revitalization of } \\
\text { volunteers and health } \\
\text { workers, NFI distribution } \\
\text { HH spraying done by } \\
\text { government }\end{array}$ & $\begin{array}{l}\text { Field } \\
\text { commentary } \\
\text { Case study }\end{array}$ & $\begin{array}{l}\text { Social mobilization considered most } \\
\text { impactful to reduce disease } \\
\text { transmission } \\
\text { NFI gave 'psychosocial support'; } \\
\text { blanket distribution late; } \\
\text { prepositioned stocks were helpful } \\
\text { Errors in IEC materials; soap was } \\
\text { scarce }\end{array}$ & $\begin{array}{l}\text { High risk of bias } \\
\text { Case study - } \\
\text { commentary, } \\
\text { limited methods }\end{array}$ \\
\hline $\begin{array}{l}\text { Wall (2011) Ann Kite } \\
\text { Yo Pale (let them } \\
\text { speak) Best Practice } \\
\text { and Lessons Learned } \\
\text { in Communication with } \\
\text { Disaster Affected } \\
\text { Communities: Haiti } \\
2010 \\
\text { Grey literature }\end{array}$ & $\begin{array}{l}\text { Cholera } \\
\text { Haiti } \\
\text { Outbreak }\end{array}$ & $\begin{array}{l}\text { Various communication } \\
\text { strategies from many } \\
\text { organizations }\end{array}$ & $\begin{array}{l}\text { Qualitative } \\
15 \text { FGD, KII } \\
\text { (not } \\
\text { described) }\end{array}$ & $\begin{array}{l}\text { Communication was effective at } \\
\text { improving trust, mitigating conflict, } \\
\text { developing relationships, and } \\
\text { gaining insights to community } \\
\text { perceptions and values } \\
\text { 2-way communication was key - } \\
\text { asking a question, sharing stories, } \\
\text { discuss an issue (face-to-face was } \\
\text { key); technical and medical } \\
\text { messages did not address fears } \\
\text { and perceptions of the disease } \\
\text { Cholera treatment centres were } \\
\text { initially rejected due to fears about } \\
\text { the origin and response to the } \\
\text { disease } \\
\text { The assessments of overall effect } \\
\text { on communication efforts on } \\
\text { cholera, as "too many organizations } \\
\text { were involved and too many } \\
\text { techniques used" } \\
\text { (p. 28) }\end{array}$ & $\begin{array}{l}\text { Medium risk of } \\
\text { bias } \\
\text { Unclear } \\
\text { methodology } \\
\text { and selective } \\
\text { reporting }\end{array}$ \\
\hline
\end{tabular}




\section{Hygiene kit distribution}

\begin{tabular}{|c|c|c|c|c|c|}
\hline $\begin{array}{l}\text { Author (year) title } \\
\text { Type }\end{array}$ & Context & $\begin{array}{l}\text { Description of } \\
\text { activities }\end{array}$ & Evaluation & Key impacts & $\begin{array}{l}\text { Bias } \\
\text { Comments }\end{array}$ \\
\hline $\begin{array}{l}\text { Unicef - Ruiz-Roman } \\
\text { (2009) Evaluation of } \\
\text { the blanket distribution } \\
\text { of non-food items as } \\
\text { part of the cholera } \\
\text { response in Zimbabwe } \\
\text { Grey literature }\end{array}$ & $\begin{array}{l}\text { Cholera } \\
\text { Zimbabwe } \\
\text { Outbreak }\end{array}$ & $\begin{array}{l}\text { 200,000 HH NFI } \\
\text { distribution (1 20L } \\
\text { bucket, } 120 \mathrm{~L} \\
\text { bucket with tap, } 30 \\
\text { water purification } \\
\text { tablets, } 3 \text { ORS } \\
\text { sachets and } 1 \text { pack } \\
\text { of information, } \\
\text { education and } \\
\text { communication } \\
\text { (IEC) materials) }\end{array}$ & $\begin{array}{l}\text { Quantitative } \\
\text { Evaluation: } 307 \mathrm{HH}\end{array}$ & $\begin{array}{l}87 \% \text { of } 307 \text { surveyed } \mathrm{HH} \\
\text { reported receiving a hygiene kit; } \\
\text { only } 33 \% \text { reported receiving all } 5 \\
\text { recommended items (differences } \\
\text { in kits) } \\
59 \% \text { of } \mathrm{HH} \text { requested additional } \\
\text { quantities - mostly from families } \\
\text { of } 6 \text { or more } \\
\text { Soap was most used item }\end{array}$ & $\begin{array}{l}\text { High risk of bias } \\
\text { Spillover effects } \\
\text { likely, selective } \\
\text { reporting }\end{array}$ \\
\hline $\begin{array}{l}\text { CRS - Pennacchia } \\
\text { (2011) Bridging the } \\
\text { Gap: Providing Water } \\
\text { and Sanitation and } \\
\text { Non-Food Item } \\
\text { Assistance to } \\
\text { Returnees, IDPs and } \\
\text { Host Communities in } \\
\text { North Kivu } \\
\text { Grey literature }\end{array}$ & $\begin{array}{l}\text { Cholera } \\
\text { DRC } \\
\text { Endemic }\end{array}$ & $\begin{array}{l}\text { NFI vouchers - } \\
\text { US } \$ 70 \text { for } 2,184 \\
\text { beneficiaries }(\mathrm{HH})- \\
\text { set a market day } \\
\text { Also WASH } \\
\text { activities, including } \\
\text { construction/rehabilit } \\
\text { ation of water } \\
\text { sources and } \\
\text { hygiene stations } \\
\text { and hygiene } \\
\text { promotion }\end{array}$ & $\begin{array}{l}\text { Field commentary } \\
332 \mathrm{HH} \text { survey } 3 \\
\text { months after case } \\
\text { study }\end{array}$ & $\begin{array}{l}3 \text { months after voucher market, } \\
\text { vulnerability score dropped from } \\
3.2 \text { to } 1.6 \text { ( } 3.0 \text { is the threshold for } \\
\text { emergency intervention) } \\
\text { Voucher - beneficiaries } \\
\text { 'empowered' to choose their own } \\
\text { needs } \\
\text { More than US } \$ 150,000 \text { pumped } \\
\text { into local economy } \\
\text { Beneficiaries thought prices (via } \\
\text { voucher market) were } \\
\text { competitive, } 80 \% \text { thought prices } \\
\text { were at or below market } \\
85 \% \text { of vendors said they } \\
\text { reduced prices out of negotiation }\end{array}$ & $\begin{array}{l}\text { High risk of bias } \\
\text { Commentary - } \\
\text { limited methods }\end{array}$ \\
\hline
\end{tabular}

\section{Environmental hygiene}

\begin{tabular}{|c|c|c|c|c|c|}
\hline $\begin{array}{l}\text { Author (year) title } \\
\text { Type }\end{array}$ & Context & $\begin{array}{l}\text { Description of } \\
\text { activities }\end{array}$ & Evaluation & Key impacts & $\begin{array}{l}\text { Bias } \\
\text { Comments }\end{array}$ \\
\hline $\begin{array}{l}\text { Steele (2008) Impact } \\
\text { of jerry can } \\
\text { disinfection in a camp } \\
\text { environment - } \\
\text { experiences in an IDP } \\
\text { camp in Northern } \\
\text { Uganda } \\
\text { Published }\end{array}$ & $\begin{array}{l}\text { Cholera } \\
\text { Uganda } \\
\text { Endemic }\end{array}$ & $\begin{array}{l}\text { Disinfecting jerry } \\
\text { cans with } 3 \% \\
\text { chlorine solution } \\
\text { using } 2 \text { methods of } \\
\text { cleaning }\end{array}$ & $\begin{array}{l}\text { Qualitative } \\
\text { Jerry cans from } 13 \\
\text { HH barrowed then } \\
\text { revisited } 3-5 \text { days } \\
\text { after cleaning }\end{array}$ & $\begin{array}{l}92 \%(11 / 12) \text { had reduced } E . \text { coli } \\
\text { after cleaning; } 75 \%(9 / 12) \text { had }<5 \\
E . \text { coli after cleaning; } 42 \%(5 / 12) \\
\text { had } 0 \text { E. coli after cleaning } \\
\text { Either method of cleaning with } \\
\text { high strength chlorine solution } \\
\text { was considered efficient at a one- } \\
\text { time disinfection } \\
\text { One-time disinfection did not } \\
\text { affect the recontamination after } \\
3-5 \text { days }\end{array}$ & $\begin{array}{l}\text { High risk of bias } \\
\text { Small sample } \\
\text { and } \\
\text { inconsistent } \\
\text { results }\end{array}$ \\
\hline $\begin{array}{l}\text { Walden (2005) } \\
\text { Container } \\
\text { contamination as a } \\
\text { possible source of a } \\
\text { diarrhoea outbreak in } \\
\text { Abou Shouk camp, } \\
\text { Darfur province, } \\
\text { Sudan } \\
\text { Published }\end{array}$ & $\begin{array}{l}\text { Shigellosis } \\
\text { Sudan } \\
\text { Outbreak }\end{array}$ & $\begin{array}{l}\text { Disinfecting jerry } \\
\text { cans with } 5 \% \\
\text { chlorine solution. } \\
13,224 \text { over } 5 \text { days } \\
\text { for about } 88 \% \text { IDP } \\
\text { camp coverage } \\
\text { Loudspeaker and } \\
\text { door to door }\end{array}$ & $\begin{array}{l}\text { Qualitative } \\
\text { Case study - } \\
\text { observation }\end{array}$ & $\begin{array}{l}\text { Number of watery and bloody } \\
\text { cases of diarrhea continued to } \\
\text { decline after the disinfection } \\
\text { (according to clinic records) } \\
\text { Response deemed more } \\
\text { important than random water } \\
\text { testing to determine the source of } \\
\text { contamination } \\
1 \text { week later, observations were } \\
\text { that people were keeping } \\
\text { containers clean }\end{array}$ & $\begin{array}{l}\text { High risk of bias } \\
\text { Case study } \\
\text { description }\end{array}$ \\
\hline $\begin{array}{l}\text { Roberts (2001) } \\
\text { Keeping clean water } \\
\text { clean in a Malawi } \\
\text { refugee camp: a } \\
\text { randomized } \\
\text { intervention trial } \\
\text { Published }\end{array}$ & $\begin{array}{l}\text { Cholera } \\
\text { Malawi } \\
\text { Endemic }\end{array}$ & $\begin{array}{l}\text { Buckets were } \\
\text { chlorinated with } \\
2.5 \mathrm{mg} / \mathrm{L} \text { solution } 8 \\
\text { times over } 2 \text { months }\end{array}$ & $\begin{array}{l}\text { Quantitative } \\
\text { Cross-sectional } 24 \\
\text { buckets }\end{array}$ & $\begin{array}{l}\text { Faecal coliform virtually } \\
\text { eliminated for } 4 \text { hours, but } \\
\text { increased after } 6 \text { hours } \\
\text { Stock solution concentrations } \\
\text { were considerably lower than } \\
\text { intended on several occasions, } \\
\text { leading to inadequate chlorination } \\
\text { Note: the chlorine concentration } \\
\text { of } 2.5 \text { mg/L is typically a drinking } \\
\text { water level and } 4 \text { magnitudes } \\
\text { weaker than the concentrations } \\
\text { of Steele et al. and Walden et al. } \\
\text { described above to disinfect } \\
\text { inanimate objects. }\end{array}$ & $\begin{array}{l}\text { High risk of } \\
\text { bias } \\
\text { Weak } \\
\text { evaluation } \\
\text { methods } \\
\text { outside the } \\
\text { larger RCT }\end{array}$ \\
\hline
\end{tabular}




\begin{tabular}{|c|c|c|c|c|c|}
\hline $\begin{array}{l}\text { Author (year) title } \\
\text { Type }\end{array}$ & Context & $\begin{array}{l}\text { Description of } \\
\text { activities }\end{array}$ & Evaluation & Key impacts & $\begin{array}{l}\text { Bias } \\
\text { Comments }\end{array}$ \\
\hline $\begin{array}{l}\text { Gartley (2013) Uptake } \\
\text { of household } \\
\text { disinfection kits as an } \\
\text { additional measure in } \\
\text { response to a cholera } \\
\text { outbreak in urban } \\
\text { areas of Haiti } \\
\text { Published }\end{array}$ & $\begin{array}{l}\text { Cholera } \\
\text { Haiti } \\
\text { Outbreak }\end{array}$ & $\begin{array}{l}1,220 \\
\text { NFI/household } \\
\text { disinfection kits } \\
\text { given to cholera } \\
\text { patients or } \\
\text { caregivers (0.5-1kg } \\
\text { soap, 14L bucket, } \\
10 \mathrm{~L} \text { jerry can, } 3.8 \mathrm{~L} \\
\text { bleach, cloth, } \\
\text { scrubbing brush, } \\
\text { instruction book) }\end{array}$ & $\begin{array}{l}\text { Quantitative } \\
208 \mathrm{HH} \text { in sequence }\end{array}$ & $\begin{array}{l}98 \% \text { of } \mathrm{HH} \text { reported using } \\
\text { contents at time of survey } \\
\text { Training changed } 1 / 3 \text { way } \\
\text { through programme - there was } \\
\text { a significant } p<0.05 \text { difference in } \\
\text { use of materials with increased } \\
\text { training focusing on using all } \\
\text { items in the kit together and } \\
\text { sharing with family members and } \\
\text { neighbours } \\
\text { Kit - US } \$ 14 \text { USD } \\
94 \% \text { of HH said instructions were } \\
\text { clear and simple }\end{array}$ & $\begin{array}{l}\text { High risk of bias } \\
\text { Sequential } \\
\text { sampling, likely } \\
\text { courtesy bias }\end{array}$ \\
\hline
\end{tabular}

WASH PACKAGE

\begin{tabular}{|c|c|c|c|c|c|}
\hline $\begin{array}{l}\text { Author (year) title } \\
\text { Type }\end{array}$ & Context & Description of activities & Evaluation & Key impacts & $\begin{array}{l}\text { Bias } \\
\text { Comments }\end{array}$ \\
\hline $\begin{array}{l}\text { ACF - Dinku (2011) } \\
\text { Emergency Water, } \\
\text { Sanitation, and } \\
\text { Hygiene Interventions } \\
\text { for AWD and Drought } \\
\text { Affected Pastorial } \\
\text { Communities in } \\
\text { Borana Zone, Ethiopia } \\
\text { Grey literature }\end{array}$ & $\begin{array}{l}\text { Acute } \\
\text { Watery } \\
\text { Diarrhoea } \\
\text { (AWD) } \\
\text { Ethiopia } \\
\text { Endemic }\end{array}$ & $\begin{array}{l}\text { Rehabilitation of wells, } \\
\text { sanitation promotion, NFI kits } \\
\text { (with WaterGuard®) to } 10,059 \\
\text { HH }\end{array}$ & $\begin{array}{l}\text { Field } \\
\text { commentary } \\
\text { Case study }\end{array}$ & $\begin{array}{l}\text { "Reduced risk of water and } \\
\text { sanitation related morbidity and } \\
\text { mortality among AWD and } \\
\text { drought affected pastoral } \\
\text { communities" } \\
\text { Reported improvements in time } \\
\text { to collect water, water } \\
\text { collection practices, } \\
\text { handwashing, latrine use, } \\
\text { garbage practices }\end{array}$ & $\begin{array}{l}\text { High risk of bias } \\
\text { Case study } \\
\text { description }\end{array}$ \\
\hline $\begin{array}{l}\text { DeGabriele (2009) An } \\
\text { emergency response } \\
\text { to humanitarian } \\
\text { WASH- related } \\
\text { emergencies in } \\
\text { Zimbabwe } \\
\text { Grey literature }\end{array}$ & $\begin{array}{l}\text { Cholera } \\
\text { Zimbabwe } \\
\text { Outbreak }\end{array}$ & $\begin{array}{l}\text { Hygiene kit distribution }(8,000 \\
\mathrm{HH}) \text {, Aquatabs } ₫ \text { to } 3,300 \mathrm{HH} \\
\text { for } 3 \text { weeks, 'cat litter' method } \\
\text { promoted, well rehabilitation } \\
\text { and water trucking }\end{array}$ & $\begin{array}{l}\text { Qualitative } \\
34 \text { KII, FGD } \\
\text { (not } \\
\text { described) }\end{array}$ & $\begin{array}{l}90 \% \text { of respondent claimed to } \\
\text { have changed hygiene } \\
\text { behaviour as a result of } \\
\text { promotion, but may not be } \\
\text { practiced consistently } \\
\text { Aquatabs } ® \text { inconsistent but } \\
\text { accepted by community; } \\
\text { Leaflet not enough to educate } \\
\text { on Aquatab® use }\end{array}$ & $\begin{array}{l}\text { High risk of bias } \\
\text { Inconsistent } \\
\text { methods }\end{array}$ \\
\hline $\begin{array}{l}\text { IWSD - Neseni (2009) } \\
\text { Evaluation of the } \\
\text { WASH Response to } \\
\text { the 2008-2009 } \\
\text { Zimbabwe Cholera } \\
\text { Epidemic and } \\
\text { Preparedness } \\
\text { Planning for Future } \\
\text { Outbreaks } \\
\text { Grey literature }\end{array}$ & $\begin{array}{l}\text { Cholera } \\
\text { Zimbabwe } \\
\text { Outbreak }\end{array}$ & $\begin{array}{l}\text { Water trucking, drilling } \\
\text { boreholes, rehabilitation of } \\
\text { wells, HWT, water quality } \\
\text { monitoring } \\
\text { Latrine construction was } \\
\text { limited, rehab of latrines, sewer } \\
\text { decongestion, rehab sewer } \\
\text { pipes } \\
\text { Hygiene: door to door, dramas, } \\
\text { traveller information, print and } \\
\text { electronic media, 'revitalization } \\
\text { of volunteers and health } \\
\text { workers, NFI distribution } \\
\text { HH spraying done by } \\
\text { government }\end{array}$ & $\begin{array}{l}\text { Field } \\
\text { commentary } \\
\text { Case study }\end{array}$ & $\begin{array}{l}\text { Social mobilization considered } \\
\text { most impactful to reduce } \\
\text { disease transmission } \\
\text { NFI gave 'psychosocial } \\
\text { support'; blanket distribution } \\
\text { late; prepositioned stocks were } \\
\text { helpful } \\
\text { Errors in IEC materials; soap } \\
\text { was scarce }\end{array}$ & $\begin{array}{l}\text { High risk of bias } \\
\text { Case study - } \\
\text { commentary, } \\
\text { limited methods }\end{array}$ \\
\hline $\begin{array}{l}\text { IOM - Condor (2011) } \\
\text { Evaluation of the } \\
\text { International } \\
\text { Organization for } \\
\text { Migration's Ongoing } \\
\text { Activities on Support } \\
\text { to the Flash Appeal for } \\
\text { the Haiti Earthquake } \\
\text { and Cholera Outbreak } \\
\text { (Sida/lOM Agreement } \\
\text { January } 2010 \text { - May } \\
\text { 2011) } \\
\text { Grey literature }\end{array}$ & $\begin{array}{l}\text { Cholera } \\
\text { Haiti } \\
\text { Outbreak }\end{array}$ & $\begin{array}{l}\text { Improvement of } 250 \text { sites } \\
\text { through hygiene promotion } \\
\text { (Community Action Groups), } \\
\text { Radio Tap Taps, and cartoon } \\
\text { newspaper } \\
\text { WASH facility } \\
\text { construction/rehabilitation/clean } \\
\text { ing (including hand washing } \\
\text { stations, water tanks and } \\
\text { latrines) to support efforts of } \\
\text { ORS focal points }\end{array}$ & $\begin{array}{l}\text { Field } \\
\text { commentary } \\
\text { Case study }\end{array}$ & $\begin{array}{l}\text { "Two-way communications with } \\
\text { affected populations and the } \\
\text { general public is a critical factor } \\
\text { in achieving scale in cholera } \\
\text { prevention health messages" } \\
\text { Low staff turnover } \\
\text { Quick and flexible funding - } \\
\text { realistic approach built on } \\
\text { experience with 'no false } \\
\text { expectations' } \\
\text { 'High value for money' with } \\
\text { Community Action Groups } \\
\text { (paid hygiene promoters for } 12 \\
\text { months); other NGOs did not } \\
\text { appreciate paying for a } \\
\text { 'volunteer' job }\end{array}$ & $\begin{array}{l}\text { High risk of bias } \\
\text { Limited } \\
\text { methods }\end{array}$ \\
\hline
\end{tabular}




\begin{tabular}{|c|c|c|c|c|c|}
\hline $\begin{array}{l}\text { Author (year) title } \\
\text { Type }\end{array}$ & Context & Description of activities & Evaluation & Key impacts & $\begin{array}{l}\text { Bias } \\
\text { Comments }\end{array}$ \\
\hline $\begin{array}{l}\text { ACF - Gauthier (2014) } \\
\text { A Real-time } \\
\text { Evaluation of ACF's } \\
\text { Response to Cholera } \\
\text { in Juba, South Sudan } \\
\text { Grey literature }\end{array}$ & $\begin{array}{l}\text { Cholera } \\
\text { South } \\
\text { Sudan } \\
\text { Outbreak }\end{array}$ & $\begin{array}{l}\text { Borehole rehabilitation; } \\
\text { 'Support' community building } \\
\text { latrines; Hygiene promotion - } \\
\text { megaphone, house to house, } \\
\text { groups; NFI kit; } \\
\text { HH/environmental disinfection }\end{array}$ & $\begin{array}{l}\text { Field } \\
\text { commentary } \\
28 \text { staff KII }\end{array}$ & $\begin{array}{l}\text { Weekly attack rate has been } \\
\text { decreasing (even prior to } \\
\text { intervention) } \\
\text { NFls not aligned with Sphere or } \\
\text { South Sudan and size not } \\
\text { adequate for large families, } \\
\text { rapidly used } \\
\text { Surge capacity and 'kick off' } \\
\text { funds were effective } \\
\text { HH disinfection actually } \\
\text { spraying community latrines } \\
\text { and high risk areas - but not a } \\
\text { priority by cluster }\end{array}$ & $\begin{array}{l}\text { High risk of bias } \\
\text { Lack of } \\
\text { consistent data }\end{array}$ \\
\hline $\begin{array}{l}\text { CRS - Pennacchia } \\
\text { (2011) Bridging the } \\
\text { Gap: Providing Water } \\
\text { and Sanitation and } \\
\text { Non-Food Item } \\
\text { Assistance to } \\
\text { Returnees, IDPs and } \\
\text { Host Communities in } \\
\text { North Kivu } \\
\text { Grey literature }\end{array}$ & $\begin{array}{l}\text { Cholera } \\
\text { DRC } \\
\text { Endemic }\end{array}$ & $\begin{array}{l}\text { Water: } 25 \text { spring } \\
\text { rehabilitations; } 3 \text { new spring } \\
\text { construction } \\
\text { Sanitation: } 20 \text { shower blocks; } \\
20 \text { laundry stations; } 2,509 \mathrm{~m} \text { of } \\
\text { drainage; } 20-15 \mathrm{~m}^{3} \text { solid waste } \\
\text { areas } \\
\text { Hygiene: } 20 \text { hygiene } \\
\text { promoters; } 28 \text { Water } \\
\text { Committees formed ( } 1 \text { for each } \\
\text { water system); Promotion via: } \\
\text { HH, schools, markets, } \\
\text { churches, radio, drama, IEC } \\
\text { book; topics: handwashing, } \\
\text { boiling of water, proper latrine } \\
\text { usage } \\
\text { NFI vouchers - US } \$ 70 \text { for } \\
2,184 \text { beneficiaries }(H H)\end{array}$ & $\begin{array}{l}\text { Field } \\
\text { commentary } \\
\text { Unclear } \\
\text { evaluation }\end{array}$ & $\begin{array}{l}90 \% \text { of } \mathrm{HH} \text { thought personal } \\
\text { hygiene improved (no sample } \\
\text { mentioned) } \\
74 \% \text { decrease in diarrhoea } \\
\text { cases in } 5 \text { months ( } 35 \text { cases in } \\
\text { September: } 9 \text { cases in } \\
\text { January); clinic records } \\
\text { Time savings to collect water: } \\
\text { average } 322 \mathrm{~m} \text { before to } 92 \mathrm{~m} \\
\text { after (also less time in insecure } \\
\text { environment) }\end{array}$ & $\begin{array}{l}\text { High risk of bias } \\
\text { Commentary - } \\
\text { limited methods }\end{array}$ \\
\hline $\begin{array}{l}\text { Tearfund - Ngegba } \\
(2002) \\
\text { Water and Sanitation } \\
\text { Programme February- } \\
\text { December } 2002 \\
\text { Jaluahun Chiefdom, } \\
\text { Kailahun District } \\
\text { Eastern Province, } \\
\text { Sierra Leone } \\
\text { Grey literature }\end{array}$ & $\begin{array}{l}\text { Bloody } \\
\text { diarrhoea } \\
\text { Sierra } \\
\text { Leone } \\
\text { Outbreak }\end{array}$ & $\begin{array}{l}\text { Water: } 8 \text { new wells dug, } 6 \\
\text { rehabilitated, } 10 \text { spring boxes } \\
\text { Sanitation: } 652 \text { pit latrines } \\
\text { Hygiene: } 8 \text { laundry areas, } \\
\text { developed community } \\
\text { management committees and } \\
\text { community health volunteers }\end{array}$ & $\begin{array}{l}\text { Field } \\
\text { commentary }\end{array}$ & $\begin{array}{l}\text { Social cohesion observed. } \\
\text { Community management } \\
\text { committees and training; } \\
\text { community health visitors } \\
\text { engage in communal activities } \\
\text { and help one another in times } \\
\text { of need } \\
50 \% \text { of interviewed } \\
\text { demonstrated knowledge of } \\
\text { diarrhoea transmission routes } \\
\text { There have been considerable } \\
\text { changes in people's attitudes, } \\
\text { especially toward open } \\
\text { defecation } \\
\text { Clinic and Ministry of Health } \\
\text { data shows diarrhoea reduction } \\
\text { from } 50 \% \text { to } 5 \% \text { in intervention } \\
\text { villages }\end{array}$ & $\begin{array}{l}\text { High risk of bias } \\
\text { Commentary - } \\
\text { limited methods }\end{array}$ \\
\hline $\begin{array}{l}\text { Grayel (2014) } \\
\text { Programme } \\
\text { d'intervention pour } \\
\text { limiter et prévenir la } \\
\text { propagation de } \\
\text { l'épidémie de choléra } \\
\text { en République } \\
\text { Démocratique du } \\
\text { Congo } \\
\text { Grey literature }\end{array}$ & $\begin{array}{l}\text { Cholera } \\
\text { DRC } \\
\text { Endemic }\end{array}$ & $\begin{array}{l}\text { Water: Rehabilitation of water } \\
10 \text { sources and } 3 \text { networks, } \\
\text { chlorination in } 3 \text { water networks } \\
\text { and } 15 \text { high risk water points, } \\
\text { pilot promotion of HWT with } \\
\text { chlorine } \\
\text { Sanitation: Improvement of } \\
\text { access to sanitation for } 2,500 \\
\text { HH } \\
\text { Hygiene: Soap distributed (not } \\
\text { described), disinfection of } \\
\text { households (spraying), hygiene } \\
\text { promotion and epidemiological } \\
\text { surveillance/control }\end{array}$ & $\begin{array}{l}\text { Qualitative } \\
7 \text { FGD; } 34 \text { KII }\end{array}$ & $\begin{array}{l}\text { Local volunteers for hygiene } \\
\text { promotion and disinfection } \\
\text { The influence of the project on } \\
\text { cholera prevalence is not as } \\
\text { strong as hoped; "little change } \\
\text { from } 2012 \text { to } 2013 \text { " } \\
\text { In the future, integrate } \\
\text { epidemiological experts to } \\
\text { better understand cholera } \\
\text { transmission pathways and } \\
\text { dynamics; } \\
\text { work on longer term (3-5 } \\
\text { years) }\end{array}$ & $\begin{array}{l}\text { Medium risk of } \\
\text { bias } \\
\text { High likelihood } \\
\text { of spillover bias } \\
\text { and reliance on } \\
\text { expert opinion }\end{array}$ \\
\hline
\end{tabular}




\begin{tabular}{|c|c|c|c|c|c|}
\hline $\begin{array}{l}\text { Author (year) title } \\
\text { Type }\end{array}$ & Context & Description of activities & Evaluation & Key impacts & $\begin{array}{l}\text { Bias } \\
\text { Comments }\end{array}$ \\
\hline $\begin{array}{l}\text { ACF - El-Mahmid } \\
\text { Zimbabwe Emergency } \\
\text { Response 01/05/2008 } \\
\text { - 30/06/2009 } \\
\text { Capitalization Report } \\
\text { Grey literature }\end{array}$ & $\begin{array}{l}\text { Cholera } \\
\text { Zimbabwe } \\
\text { Outbreak }\end{array}$ & $\begin{array}{l}\text { Water: } 13 \text { bladders and } 3 \text { rigid } \\
\text { tanks at cholera treatment units } \\
\text { (CTUs) with some taps; Water } \\
\text { trucking to supply } \\
\text { bladders/tanks at CTUs; } 18 \\
\text { water points repaired and } \\
\text { disinfected with } 2 \% \text { HTH; } \\
\text { Repaired } 5 \text { springs; } 81 \\
\text { boreholes repaired ( } 19 \text { in } \\
\text { schools) - water committees } \\
\text { and spare parts too } \\
5 \text { new boreholes in health } \\
\text { clinics } \\
\text { Hygiene: Hygiene promotion to } \\
29,000 ; \text { Training on chlorine } \\
\text { solution for health volunteers; } \\
4000 \text { hygiene kits }(1 \text { water } \\
\text { container } 30 \mathrm{~L} \text { with lid and cap, } \\
1 \text { plastic bucket } 15 \text { L with lid, } 1 \\
\text { kg of green soap, } 2 \text { stripes of } \\
\text { Aquatabs } \circledast \text { with leaflets) }\end{array}$ & $\begin{array}{l}\text { Field } \\
\text { commentary }\end{array}$ & $\begin{array}{l}\text { Emergency experts in the field } \\
\text { were main added value } \\
\text { Bladder used to establish safe } \\
\text { drinking water for } 34,912 \\
\text { people ( } 4 \mathrm{~L} / \mathrm{p} / \mathrm{d}) \\
\text { Distribution point: FCR } 0.1- \\
1.3 \mathrm{mg} / \mathrm{L} \text {; turbidity }<5 \text { NTU } \\
\mathrm{HH}(54 \text { samples) Average: } \\
0.25 \mathrm{mg} / \mathrm{L} ; \mathrm{NTU}<5 ; 84 \text { samples } \\
0.1-0.6 \mathrm{mg} / \mathrm{L}\end{array}$ & $\begin{array}{l}\text { High risk of bias } \\
\text { Commentary - } \\
\text { limited methods }\end{array}$ \\
\hline $\begin{array}{l}\text { ACF (2007) - } \\
\text { UNOCHA Emergency } \\
\text { Funding Water and } \\
\text { Sanitation Program in } \\
\text { Kebri Dehar District, } \\
\text { Somali Region } \\
\text { Grey literature }\end{array}$ & $\begin{array}{l}\text { Diarrhoea } \\
\text { Somalia } \\
\text { Outbreak }\end{array}$ & $\begin{array}{l}\text { Water: } 6 \text { community wells } \\
\text { rehabilitated ( } 7095 \text { people); } \\
120 \text { m3/day for } 3 \text { weeks for } \\
3500 \text { people with water } \\
\text { trucking; Widespread well } \\
\text { chlorination, } 150 \text { surface water } \\
\text { storage structures (birkhats); } \\
1,554 \text { bottles of WaterGuard® } \\
\text { given to families with birkhats } \\
\text { (259 HH); } 45 \text { bottles given to } \\
\text { schools; } 1 \text { bottle treats } 1,000 \mathrm{~L} \\
\text { NFI kits: } 500 \text { kits: ( } 4 \text { pieces of } \\
\text { soap, water container (no size), } \\
\text { cup with handle, } 4-6 \text { bottles of } \\
\text { WaterGuard® } \\
\text { Hygiene: } 4809 \text { people, } \\
\text { including } 424 \text { community } \\
\text { people; Mostly women, children } \\
\text { and 'community people'; } \\
\text { Topics: Disinfection, storage, } \\
\text { handling }\end{array}$ & $\begin{array}{l}\text { Field } \\
\text { commentary } \\
\text { Case study }\end{array}$ & $\begin{array}{l}\text { Case management improved, } \\
\text { and the case fatality rate } \\
\text { dropped significantly after the } \\
\text { NGO's intervention, bringing it } \\
\text { to an acceptable standard of < } \\
5 \% \text { (from } 11.7 \% \text { to } 4.9 \% \text { and } \\
2.8 \% \text { ) } \\
\text { Microbiological testing not } \\
\text { sufficiently carried out on } \\
\text { rehabilitated/disinfected water } \\
\text { sources; } 7 \text { were tested - all } \\
\text { had } 12-30 \text { faecal } \\
\text { coliform/100mL } \\
\text { Hygiene kits had logistic } \\
\text { delays; contract delays }\end{array}$ & $\begin{array}{l}\text { High risk of bias } \\
\text { Case study } \\
\text { description }\end{array}$ \\
\hline $\begin{array}{l}\text { ACF Grayel (2011) } \\
\text { Evaluation externe - } \\
\text { Réponse d'urgence à } \\
\text { l'épidémie de choléra } \\
\text { en Haïti } \\
\text { Grey literature }\end{array}$ & $\begin{array}{l}\text { Cholera } \\
\text { Haiti } \\
\text { Outbreak }\end{array}$ & $\begin{array}{l}\text { Water - Distribution of HHWT } \\
\text { kits/ceramic filters for turbid } \\
\text { waters; mobile drinking water } \\
\text { station; Antenna WATA. } 260 \\
\text { water supply points } \\
\text { Sanitation - construction of } 20 \\
\text { public latrines } \\
\text { Hygiene - } \\
\text { Sensitization/education } \\
\text { 250,000 people; distribution of } \\
\text { hygiene kits (soap, Aquatabs } § \\
\text { for } 15 \text { days); chlorination of } \\
\text { water buckets; disinfection of } \\
\text { meeting/public spaces } \\
\text { (spraying) }\end{array}$ & $\begin{array}{l}\text { Qualitative } \\
\text { Informal } \\
\text { interviews } \\
\text { with local } \\
\text { stakeholders } \\
\text { and } \\
\text { beneficiaries }\end{array}$ & $\begin{array}{l}\text { Decrease of attack rate (not } \\
\text { quantified and could be natural } \\
\text { trend) } \\
\text { Improved water quality (no } \\
\text { systematic assessment) } \\
\text { Legal/political difficulties } \\
\text { HH/public chlorine spraying } \\
\text { planned but stopped. }\end{array}$ & $\begin{array}{l}\text { High risk of bias } \\
\text { Expert opinion. } \\
\text { "informal } \\
\text { conversations", } \\
\text { limited number } \\
\text { of site visits }\end{array}$ \\
\hline $\begin{array}{l}\text { Simpson - Real Time } \\
\text { Evaluation of the } \\
\text { Cholera Response in } \\
\text { Zimbabwe } 09 \\
\text { February - } 19 \\
\text { February } 2009 \\
\text { Grey literature }\end{array}$ & $\begin{array}{l}\text { Cholera } \\
\text { Zimbabwe } \\
\text { Outbreak }\end{array}$ & $\begin{array}{l}\text { Water: Aquatabs } ® \text { in hygiene } \\
\text { kit; water tankering; } \\
\text { rehabilitation of wells; new } \\
\text { boreholes } \\
\text { Hygiene: Hygiene promotion - } \\
\text { volunteers used (but other } \\
\text { NGOs paid causing issues) } \\
29,000 \mathrm{HH} \text { receive hygiene kits } \\
\text { (not described further) }\end{array}$ & $\begin{array}{l}\text { Field } \\
\text { commentary } \\
100 \mathrm{KII} \text { (some } \\
\text { beneficiaries) }\end{array}$ & $\begin{array}{l}\text { Prepositioned stock key (with } \\
\text { response scenarios) } \\
\text { Existing public health } \\
\text { progamme; decision to scale } \\
\text { up to response difficult to } \\
\text { assess - trigger needed } \\
\text { NFIs materials lacking, quantity } \\
\text { (quality ok), beneficiaries } \\
\text { appreciated } \\
\text { Emergency staff available }\end{array}$ & $\begin{array}{l}\text { High risk of bias } \\
\text { Commentary - } \\
\text { limited methods }\end{array}$ \\
\hline
\end{tabular}




\section{APPENDIX B - SEARCHING SUMMARY}

\begin{tabular}{|c|c|c|c|}
\hline Database & & Date & Results \\
\hline Scopus & $\begin{array}{l}\text { WASH intervention string ( } 9 \text { sets) AND } \\
\text { context group AND LMIC country } \\
\text { string AND } 1995 \text { - present }\end{array}$ & $\begin{array}{l}11-12 \text { November } \\
2015\end{array}$ & 666 \\
\hline Web of Science & $\begin{array}{l}\text { WASH intervention string (9 sets) AND } \\
\text { context string AND } 1995 \text { - present } \\
\text { (topic search) }\end{array}$ & $\begin{array}{l}16 \text { November } \\
2015\end{array}$ & 4,163 \\
\hline $\begin{array}{l}\text { Ovid Medline } \\
\text { Ovide Medline In-Process and } \\
\text { other non-index citations; } \\
\text { Evidence Based Medicine } \\
\text { Reviews full text - Cochrane } \\
\text { Database of Systematic } \\
\text { Reviews (DSR), ACP Journal } \\
\text { Club and (Database of Abstracts } \\
\text { of Reviews of Effects) DARE }\end{array}$ & $\begin{array}{l}\text { WASH intervention strings (9 sets) } \\
\text { AND context string AND } 1995 \text { - } \\
\text { present (abstract, title) }\end{array}$ & $\begin{array}{l}23 \text { November } \\
2015\end{array}$ & 2,315 \\
\hline Google Scholar & $\begin{array}{l}48-2 \text { and } 3 \text { word searches: WASH } \\
\text { intervention AND emergency or } \\
\text { disaster; first } 2 \text { pages }\end{array}$ & $\begin{array}{l}25 \text { November } \\
2015\end{array}$ & 756 \\
\hline LILACS (Spanish/English) & $\begin{array}{l}\text { WASH intervention strings ( } 4 \text { sets - } \\
\text { water, sanitation, hygiene, WASH) } \\
\text { AND context string (abstract words) }\end{array}$ & $\begin{array}{l}25 \text { November } \\
2015\end{array}$ & 756 \\
\hline IDEAS & $\begin{array}{l}\text { WASH intervention strings ( } 4 \text { sets - } \\
\text { water, sanitation, hygiene, WASH) } \\
\text { AND context string (all record types; } \\
\text { abstract, 1995-2015) }\end{array}$ & $\begin{array}{l}27 \text { November } \\
2015\end{array}$ & 328 \\
\hline ArticleFirst - WorldCat (French) & $\begin{array}{l}\text { water/sanitation/hygiene AND context } \\
\text { key words AND 1995-2015; keyword }\end{array}$ & $\begin{array}{l}11 \text { December } \\
2015\end{array}$ & 83 \\
\hline Academic Search Premier & $\begin{array}{l}15-2 \text { word searches; } \\
\text { water/sanitation/hygiene; } \\
\text { disaster/outbreak }\end{array}$ & $\begin{array}{l}11 \text { December } \\
2015\end{array}$ & 625 \\
\hline $\begin{array}{l}\text { Academic Search Premier } \\
\text { (French) }\end{array}$ & $\begin{array}{l}9-2 \text { word searches; } \\
\text { water/sanitation/hygiene; context }\end{array}$ & $\begin{array}{l}11 \text { December } \\
2015\end{array}$ & 634 \\
\hline \multicolumn{3}{|r|}{ Total } & 10,326 \\
\hline
\end{tabular}

\begin{tabular}{|l|l|l|c|}
\hline Source & Description & Date & Results \\
\hline Web searching & NGO websites & September 2015- & March 2016 \\
& UN (Unicef, WHO, UNHCR) & \\
& Government agencies & \\
& Information hubs (ALNAP, ReliefWeb) & \\
& Development banks & \\
& Grey literature repositories & \\
\hline Direct communication & Mass emails to WASH cluster & September 2015- & February 2016 \\
& Targeted (individual) emails & \\
& Web postings & \\
& Personal contacts & \\
& Conference presentations & \\
\hline
\end{tabular}

Summary
\begin{tabular}{|l|l|}
\hline Source & Results \\
\hline Academic databases & 10,326 \\
\hline Internet searching & 2,676 \\
\hline Direct communication & 2,024 \\
\hline Total & 15,026 \\
\hline
\end{tabular}




\section{Search update}

In September 2016, the search strings were re-run to check for updated studies. Dates were restricted to 2015-2016. Additionally, local names for some products were searched to ensure searching was comprehensive. For example, 'gadyen dlo' is a Haitian word for WaterGuard or the Safe Water System that has been promoted in several countries.

\begin{tabular}{|c|c|c|c|}
\hline Database & & Date & Results \\
\hline Scopus & $\begin{array}{l}\text { WASH intervention string (9 sets) } \\
\text { AND context group AND LMIC } \\
\text { country string AND 2015-2016 }\end{array}$ & September 2016 & 58 \\
\hline Web of Science & $\begin{array}{l}\text { WASH intervention string (9 sets) } \\
\text { AND context string AND 2015-2016 } \\
\text { (topic search) }\end{array}$ & September 2016 & 2,180 \\
\hline Ovid Medline & $\begin{array}{l}\text { WASH intervention strings (9 sets) } \\
\text { AND context string AND 2015-2016 } \\
\text { (abstract, title) }\end{array}$ & September 2016 & 2,368 \\
\hline Cochrane & $\begin{array}{l}\text { WASH intervention strings (9 sets) } \\
\text { AND context string AND 2015-2016 } \\
\text { (abstract, title) }\end{array}$ & September 2016 & 610 \\
\hline Google Scholar & $\begin{array}{l}48-2 \text { and } 3 \text { word searches: WASH } \\
\text { intervention AND emergency or } \\
\text { disaster; first } 2 \text { pages }\end{array}$ & September 2016 & 480 \\
\hline LILACS (Spanish/English) & $\begin{array}{l}\text { WASH intervention strings (4 sets - } \\
\text { water, sanitation, hygiene, WASH) } \\
\text { AND context string (abstract words) }\end{array}$ & September 2016 & 99 \\
\hline IDEAS & $\begin{array}{l}\text { WASH intervention strings ( } 4 \text { sets - } \\
\text { water, sanitation, hygiene, WASH) } \\
\text { AND context string (all record types; } \\
\text { abstract, 2015-2016) }\end{array}$ & September 2016 & 230 \\
\hline $\begin{array}{l}\text { ArticleFirst - WorldCat } \\
\text { (French) }\end{array}$ & $\begin{array}{l}\text { Water/sanitation/hygiene AND } \\
\text { context key words AND 2015-2016; } \\
\text { keyword }\end{array}$ & September 2016 & 46 \\
\hline Academic Search Premier & $\begin{array}{l}15-2 \text { word searches; } \\
\text { water/sanitation/hygiene; } \\
\text { disaster/outbreak; 2015-2016 }\end{array}$ & September 2016 & 571 \\
\hline $\begin{array}{l}\text { Academic Search Premier } \\
\text { (French) }\end{array}$ & $\begin{array}{l}9-2 \text { word searches; } \\
\text { water/sanitation/hygiene; context; } \\
2015-2016\end{array}$ & September 2016 & 42 \\
\hline & & Total & 6,684 \\
\hline
\end{tabular}




\section{Example search string for databases}

Keyword strings were used to search databases. Keyword strings for the eight WASH interventions (in addition to a 'WASH' intervention) were searched with other strings for emergency contexts, low and middle-income countries, outcomes and included dates. Search strings were combined using the 'AND' operator; example strings are described below.

\begin{tabular}{|c|c|}
\hline Keyword string & Keyword string \\
\hline $\begin{array}{l}\text { Intervention } \\
\text { (example: water } \\
\text { access) }\end{array}$ & $\begin{array}{l}\text { ("water access" OR "source rehabilitation" OR "source cleaning" OR "water source" } \\
\text { OR "protected source" OR "unprotected source" OR "improved source" OR } \\
\text { "unimproved source" OR "contaminated source" OR "water quality" OR "water } \\
\text { quantity" OR "tanker"” OR "water truck" OR "well rehabilitation" OR "well cleaning" OR } \\
\text { "dug well" OR "tube well" OR "point source" OR "non-point source" OR river OR } \\
\text { stream OR canal OR "drinking water") }\end{array}$ \\
\hline Year & 1995-present \\
\hline Context & $\begin{array}{l}\text { (emergency OR emergencies OR crisis OR "emergency response" OR "complex } \\
\text { emergenc*" OR disaster OR flood OR tsunami OR outbreak* OR earthquake OR } \\
\text { drought* OR endemic OR pandemic OR hurricane OR typhoon OR "failed state" OR } \\
\text { conflict OR war OR refugee OR "IDP" OR "internally displaced" OR entrapped or } \\
\text { humanitarian) }\end{array}$ \\
\hline Outcomes & $\begin{array}{l}\text { (diarrhea OR diarrhoea OR outbreak OR "waterborne diseases" OR "disease burden" } \\
\text { OR "disease risk" OR "disease reduction" OR "DALY" OR mortality OR morbidity OR } \\
\text { prevalence OR evidence OR effectiveness OR "cost effectiveness" OR cost- } \\
\text { effectiveness OR economic OR efficacy OR "quality of life" OR "QOL" OR psycosocial } \\
\text { OR ebola OR cholera OR "hepatitis E" OR "hep e" OR "use of service" OR use-of- } \\
\text { service OR "effective use" OR "sustained use" OR uptake OR up-take OR "up take" } \\
\text { OR "EVD") }\end{array}$ \\
\hline $\begin{array}{l}\text { Low and middle- } \\
\text { income countries }\end{array}$ & $\begin{array}{l}\text { ( "LMIC" OR "low and middle income countr*" OR "low-and-middle-income" OR } \\
\text { "low income country" OR "low-income-country" OR "middle income country" OR } \\
\text { "middle-income-country" OR afghanistan OR libya OR albania OR macedonia } \\
\text { OR algeria OR madagascar OR "American Samoa" OR malawi OR angola OR } \\
\text { malaysia OR armenia OR maldives OR azerbaijan OR mali OR bangladesh OR } \\
\text { "Marshall Islands" OR belarus OR mauritania OR belize OR mauritius OR benin } \\
\text { OR mexico OR bhutan OR micronesia OR bolivia OR moldova OR bosnia OR } \\
\text { herzegovina OR mongolia OR botswana OR montenegro OR brazil OR morocco } \\
\text { OR bulgaria OR mozambique OR "Burkina Faso" OR myanmar OR burundi OR } \\
\text { namibia OR "Cabo Verde" OR nepal OR cambodia OR nicaragua OR cameroon } \\
\text { OR niger OR "Central African Republic" OR "CAR" OR nigeria OR chad OR } \\
\text { pakistan OR china OR palau OR colombia OR panama comoros OR "Papua } \\
\text { New Guinea" OR congo OR paraguay OR congo OR peru OR "Costa Rica" OR } \\
\text { philippines OR "Ivory Coast" OR "Cote d'Ivoire" OR romania OR cuba OR } \\
\text { rwanda OR djibouti OR samoa OR dominica OR "Sao Tome" OR principe OR } \\
\text { "Dominican Republic" OR senegal OR ecuador OR serbia OR egypt OR "Sierra } \\
\text { Leone" OR "El Salvador" OR "Solomon Islands" OR eritrea OR somalia OR } \\
\text { ethiopia OR "South Africa" OR fiji OR "South Sudan" OR gabon OR "Sri Lanka" } \\
\text { OR gambia OR "St. Lucia" OR "Saint Lucia" OR georgia OR "St. Vincent" OR } \\
\text { "Saint Vincent" OR grenadines OR ghana OR sudan OR grenada OR suriname } \\
\text { OR guatemala OR swaziland OR guinea OR syrian OR syria OR guinea-bissau } \\
\text { OR tajikistan OR guyana OR tanzania OR haiti OR thailand OR honduras OR } \\
\text { timor-leste OR "Timor Leste" OR india OR togo OR indonesia OR tonga OR } \\
\text { iran OR tunisia OR iraq OR turkey OR jamaica OR turkmenistan OR jordan } \\
\text { OR tuvalu OR kazakhstan OR uganda OR kenya OR ukraine OR kiribati OR } \\
\text { uzbekistan OR korea OR vanuatu OR kosovo OR vietnam OR "Kyrgyz } \\
\text { Republic" OR kyrgyzstan OR "West Bank" OR gaza OR lao OR laos OR } \\
\text { yemen OR lebanon OR zambia OR lesotho OR zimbabwe OR liberia OR } \\
\text { "middle-east" OR "middle east" OR "Africa" OR "Sub-Saharan Africa" OR "Central } \\
\text { America" OR "Latin America" OR "Caribbean" OR "South America" OR "Central } \\
\text { Asia" OR "East Asia" OR pacific OR "South Asia" OR "Asia" OR "South-east } \\
\text { Asia" OR "southeast Asia" OR "South east Asia") }\end{array}$ \\
\hline
\end{tabular}

\section{Example website searches with keywords}

For websites that were not equipped to handle complex search strings, basic keywords within the scope of WASH were used in combination. Example keyword searches include: 


\section{APPENDIX C - SUMMARY OF EVIDENCE}

To establish the summary of evidence from multiple studies of varying qualities and study designs, a protocol was developed to clearly communicate the overall evidence for outcomes and interventions. The summary of evidence protocol is based on Grading of Recommendations Assessment, Development and Evaluation (GRADE) assessment of evidence outlined in Cochrane Review. However, some modifications were made so there would be less emphasis on randomized control trials (RCT), which are known to be rarely carried out in humanitarian research. The summary of evidence is described through four categories to give the reader levels of confidence in the quality of the outcomes and interventions. The four hierarchal categories are taken directly from GRADE and Cochrane.

- High - further research is very unlikely to change our confidence in the estimate of effect or accuracy.

- Moderate - further research is likely to have an important impact on our confidence in the estimate of effect or accuracy and may change the estimate.

- Low - further research is very likely to have an important impact on our confidence in the estimate of effect or accuracy and is likely to change the estimate.

- Very low - any estimate of effect or accuracy is very uncertain.

A three-step evaluation process is used to determine the level of evidence with transparency. Each outcome (health, use, and barrier/facilitator) is assessed individually. The baseline of evidence (Step 1) is determined by the study designs. Steps 2 and 3 downgrade or upgrade the baseline evidence considering biases, effect size, consistency and generalizability (Figure C.1). Definitions for upgrading and downgrading are below the figure.

The overall evidence for the intervention is then balanced between the outcomes assessed. Outcomes with the most studies are weighted heavier; however, judgement and group discussions should be used to appreciate the definitions of 'high,' 'moderate,' 'low,' and 'very low'.

\section{Figure C.1: Level of evidence assessment. Source: The research team}

Step 1: Evidence baseline established from study designs

$\begin{array}{lll}\text { Study design } & & \text { Summary of evidence } \\ \text { RCT } & \rightarrow & 4-\text { High } \\ \text { Control groups } & \rightarrow & 3-\text { Moderate } \\ \text { Cross-sectional, } & \rightarrow & - \text { Low } \\ \text { observation, qualitative } & & \\ \text { Field observation } & \rightarrow & 1-\text { Very low }\end{array}$

Step 2: Factors that reduce the evidence baseline (1 step per point if applicable)

- High bias in half or more of the studies included in the outcome

- Unexplained heterogeneity

- Imprecision - small sample sizes

Step 3: Factors that increase the evidence baseline

(1 step per point if applicable, maximum 2-step increase)

- Large magnitude of effect

- Evidence of dose-response relationship

- Confidence in effect (confidence intervals)

- Generalizability (multiple studies across different contexts with consistent results) 
Step 1: Start with the study design evaluating the outcome. In situations with a mixture of research designs, the most frequent study design controls. When the same number of studies is in each category, start with 'low.'

Step 2: The quality of studies is downgraded. One step down for each of the criteria identified. Level 1 is the lowest possible.

- High bias: Half or more of the studies are high bias. Confidence in the results and conclusions lessens with high bias evaluations and can be a major limitation to the intervention effect.

- Inconsistency of results: Studies have a wide range of effects or estimates. Contradictory conclusions or factors that do not explain variation/heterogeneity.

- Imprecision of results: Studies have limited sample sizes, so application and implication of conclusions are doubted.

Step 3: Factors that upgrade studies include:

- Large magnitude of effect: Studies with low and medium bias that conclude a 'large effect size' (e.g. RR >2 or RR <0.5) that is in agreement with other studies.

- Dose-response: Evidence that outcomes change with a dose-response relationship.

- Confidence in effect: Narrow range of rates or calculated effect size and confidence intervals. Consistency of impact and factors.

- Generalizability: Multiple studies across different contexts with consistent results.

Note: the maximum upgrade is 2 and should be justified. 


\section{APPENDIX D - RISK OF BIAS FOR INDIVIDUAL STUDIES}

Risk of bias was separate between quantitative and qualitative studies (including field commentary). Additional procedures are found in the review protocol (Yates, Vijcic et al., 2015).

\section{QUANITATIVE STUDIES}

To determine the risk of bias in quantitative studies (experimental, quasi-experimental, and non-experimental), an assessment tool was developed, based on the Cochrane Handbook 'risk of bias' tool while also drawing heavily on the structuring and description by Baird et al (2013). We assessed the risk of bias through five categories: 1) selection and confounding; 2) spillover effects and contamination; 3) incomplete outcome; 4) selective reporting; and 5) other bias. Similarly described by Baird et al (2013):

- Selection and confounding: addresses the issue of evaluation design. Allocations, selection of beneficiaries, targeting, and matching concerns are represented in this category.

- Spillover effects and contamination - Addresses the issue of spillovers from the treatment to the control group. Not controlling for outside factors or for additional interventions in the area also has spillover effects.

- Incomplete outcome - Addresses the issue of whether analysis of all relevant outcomes was reported or whether there appears to be selection in reporting. Loss to follow-up or missing data can reduce the power of the research design as well as potentially introduce bias with unequal loss of sample between groups.

- Selective reporting - Authors use a credible analysis method and report on all intended outcomes. Some research is funded by manufacturers of products, which can lead to selective reporting of only favourable outcomes.

- Other risks of bias - This category is for any number of other risks of bias present in the report. Self-reported data is of particular concern for our analysis. Also, retrospective baseline data, data using inappropriate methods, and changing follow-up methods or procedures are examples of other potential biases. This is the most subjective of the five categories.

Each study is scored across the five categories as 'low risk,' 'medium risk,' 'high risk' or 'unclear.' The overall determination for the risk of bias for that study is assessed with Figure D.1, summarizing the five categories into a single quality assessment for each qualitative study. 
Figure D.1: Quantitative risk of bias summary

\begin{tabular}{|l|l|}
\hline Risk of bias & 'Low risk' assessed in categories \\
\hline Low risk & $4-5$ 'low risk' scores \\
\hline Medium risk & 3 'low risk' scores \\
\hline High risk & $1-2$ 'low risk' scores \\
\hline
\end{tabular}

Figure D.2: Summary risk of bias for quantitative studies

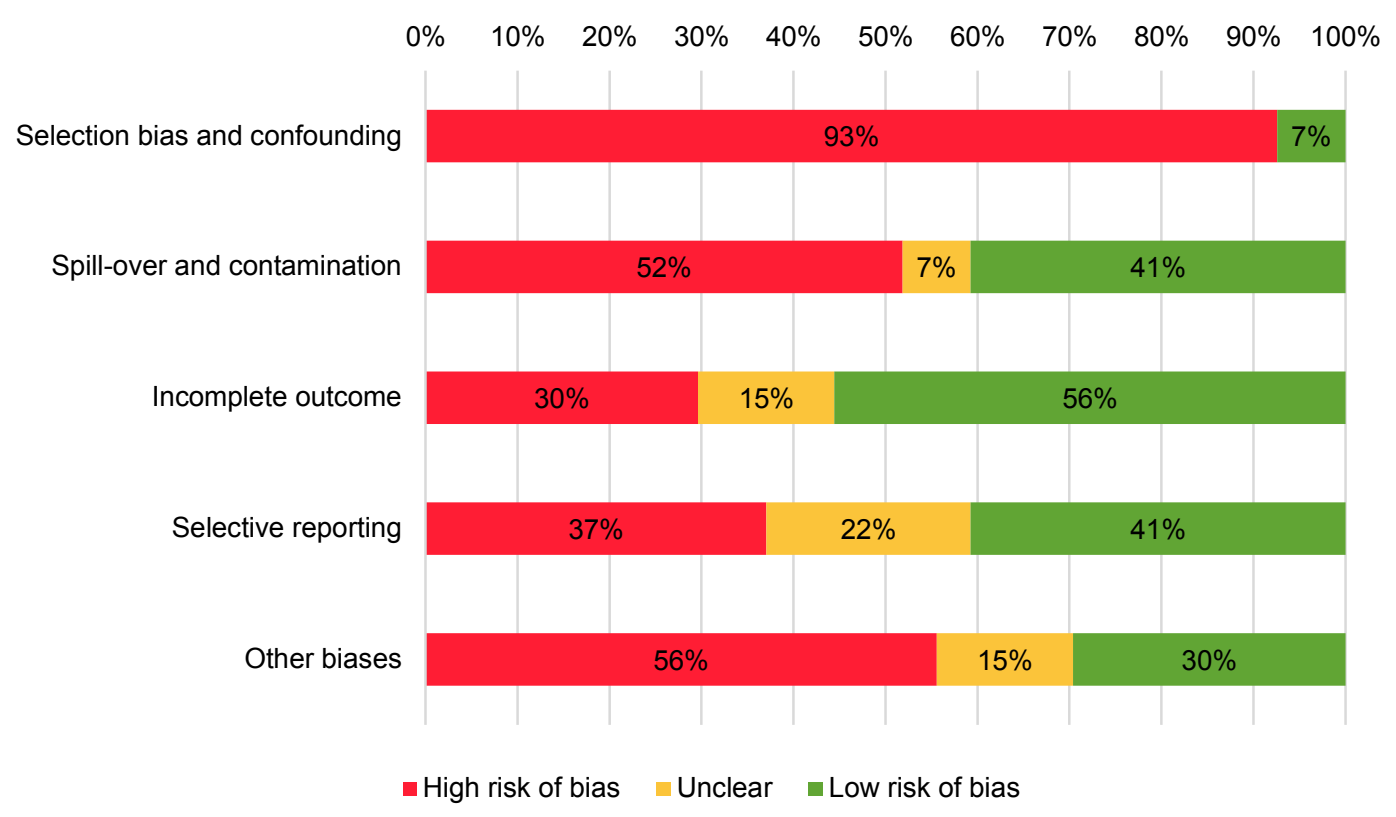

Figure D.3: Overall risk of bias score for quantitative studies

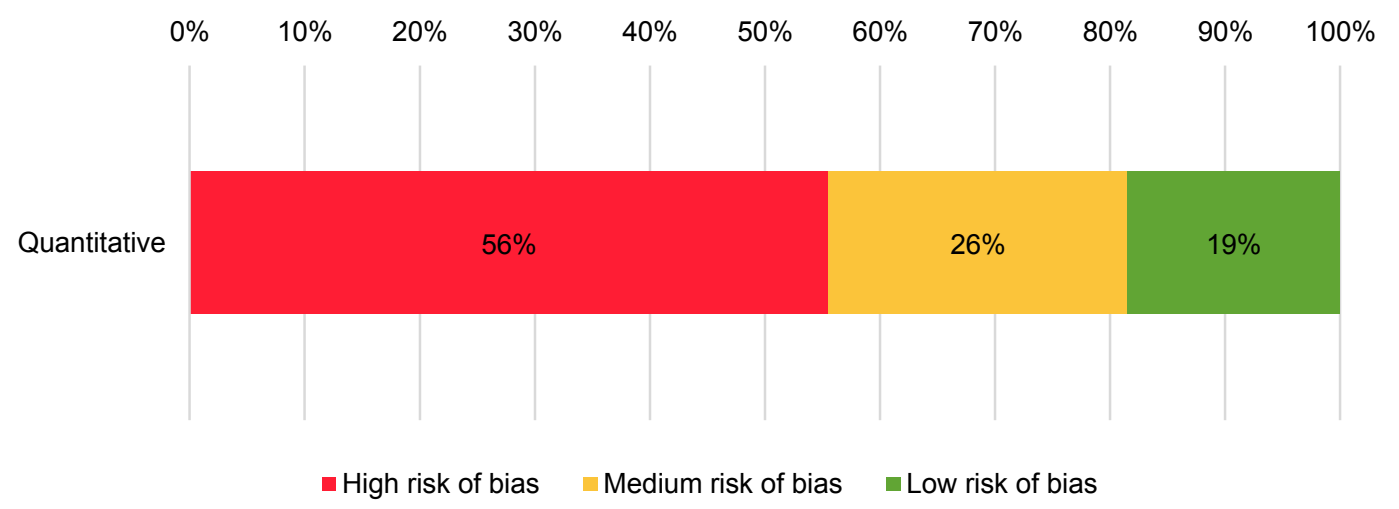


Figure D.4: Individual assessment of quantitative studies

\begin{tabular}{|c|c|c|c|c|c|c|}
\hline & $\begin{array}{l}\text { Selection bias } \\
\text { and confounding }\end{array}$ & $\begin{array}{l}\text { Spillover and } \\
\text { contamination }\end{array}$ & $\begin{array}{l}\text { Incomplete } \\
\text { outcome }\end{array}$ & $\begin{array}{l}\text { Selective } \\
\text { reporting }\end{array}$ & $\begin{array}{l}\text { Other } \\
\text { biases }\end{array}$ & Overall \\
\hline Contzen and Mosler, 2013 & High & Low & Low & Low & High & Medium \\
\hline Mong, Kaiser et al., 2001 & High & High & High & High & High & High \\
\hline Ruiz-Roman, 2009 & High & High & Unclear & High & High & High \\
\hline Date, Person et al., 2013 & High & High & Low & Unclear & Unclear & High \\
\hline ACF, 2009 & High & High & High & High & High & High \\
\hline Colwell, Huq et al., 2003 & High & High & Low & Low & Low & Medium \\
\hline Conroy, Meegan et al., 2001 & High & Low & High & High & High & High \\
\hline Doocy and Burnham, 2006 & Low & Low & Low & Low & Unclear & Low \\
\hline Huq, Yunus et al., 2010 & High & Low & Low & Low & High & Medium \\
\hline Imanishi, Kweza et al., 2014 & High & Low & Low & Low & High & Medium \\
\hline Dunston, McAfee et al., 2001 & High & High & Low & High & High & High \\
\hline Roberts, Chartier et al., 2001 & Low & Low & Unclear & Low & High & Low \\
\hline Meyer Capps and Njiru, 2015 & High & Low & Low & Low & High & Medium \\
\hline Dinku, 2011, ACF, 2014 & High & High & High & High & Unclear & High \\
\hline Dinku, 2011 & High & Low & High & High & High & High \\
\hline $\begin{array}{l}\text { Lantagne and Clasen, } 2012 \text { - } \\
\text { Nepal }\end{array}$ & High & Unclear & Low & Low & Low & Medium \\
\hline $\begin{array}{l}\text { Lantagne and Clasen, } 2012 \text { - } \\
\text { Kenya }\end{array}$ & High & Low & Low & Low & Low & Low \\
\hline $\begin{array}{l}\text { Libessart and Hammache, } \\
2000\end{array}$ & High & Low & High & Unclear & High & High \\
\hline Gartley, Valeh et al., 2013 & High & High & Unclear & High & High & High \\
\hline $\begin{array}{l}\text { Yates, Armitage et al., } 2015 \text { - } \\
\text { DRC }\end{array}$ & High & High & Low & Low & Low & Medium \\
\hline $\begin{array}{l}\text { Yates, Armitage et al., } 2015 \text { - } \\
\text { Sierra Leone }\end{array}$ & High & Low & Low & Low & Low & Low \\
\hline $\begin{array}{l}\text { Yates, Armitage et al., } 2015 \text { - } \\
\text { Haiti }\end{array}$ & High & Low & Low & Low & Low & Low \\
\hline Einarsdbttir, Passa et al., 2001 & High & High & High & High & High & High \\
\hline ACF, 2014 & High & High & Low & High & Low & High \\
\hline Grayel, 2014 & High & High & High & Low & Unclear & High \\
\hline Tokplo, 2015 & High & High & Low & Unclear & High & High \\
\hline Cavallaro, Harris et al., 2011 & High & Low & Unclear & Unclear & Low & High \\
\hline
\end{tabular}

\section{QUALITATIVE AND FIELD COMMENTARY STUDIES}

The qualitative assessment has been adapted from Spencer et al. (2003) Quality in Qualitative Evaluation: A Framework for assessing research evidence. The quality assessment is evaluated on four appraisal questions. Each study was scored across the four appraisal questions categories: 1) design, 2) bias, 3) data collection, and 4) clarity of finding as 'low risk,' 'medium risk' 'high risk,' or 'unclear.' The overall determination for the risk of bias for that study is assessed with the table below.

- Design: The overall design of the research is considered, especially the targeting of the research population.

- Bias: How representative is the research population and are there obvious biases that affect the findings?

- Data collection: How was the data collected, recorded (audio, video, transcribed)? Who collected the information?

- Clarity of findings: Do the conclusions match what could be achieved from the study design? Is there an inherent logic to the conclusions? 
Figure D.5: Risk of bias summary

\begin{tabular}{|l|l|}
\hline Risk of bias & 'Low risk' assessed in categories \\
\hline Low risk & 3 or more 'low risk' score \\
\hline Medium risk & 2 'low risk' scores \\
\hline High risk & 1 or less 'low risk' score \\
\hline
\end{tabular}

Figure D.6: Risk of bias for qualitative and field commentary studies by category

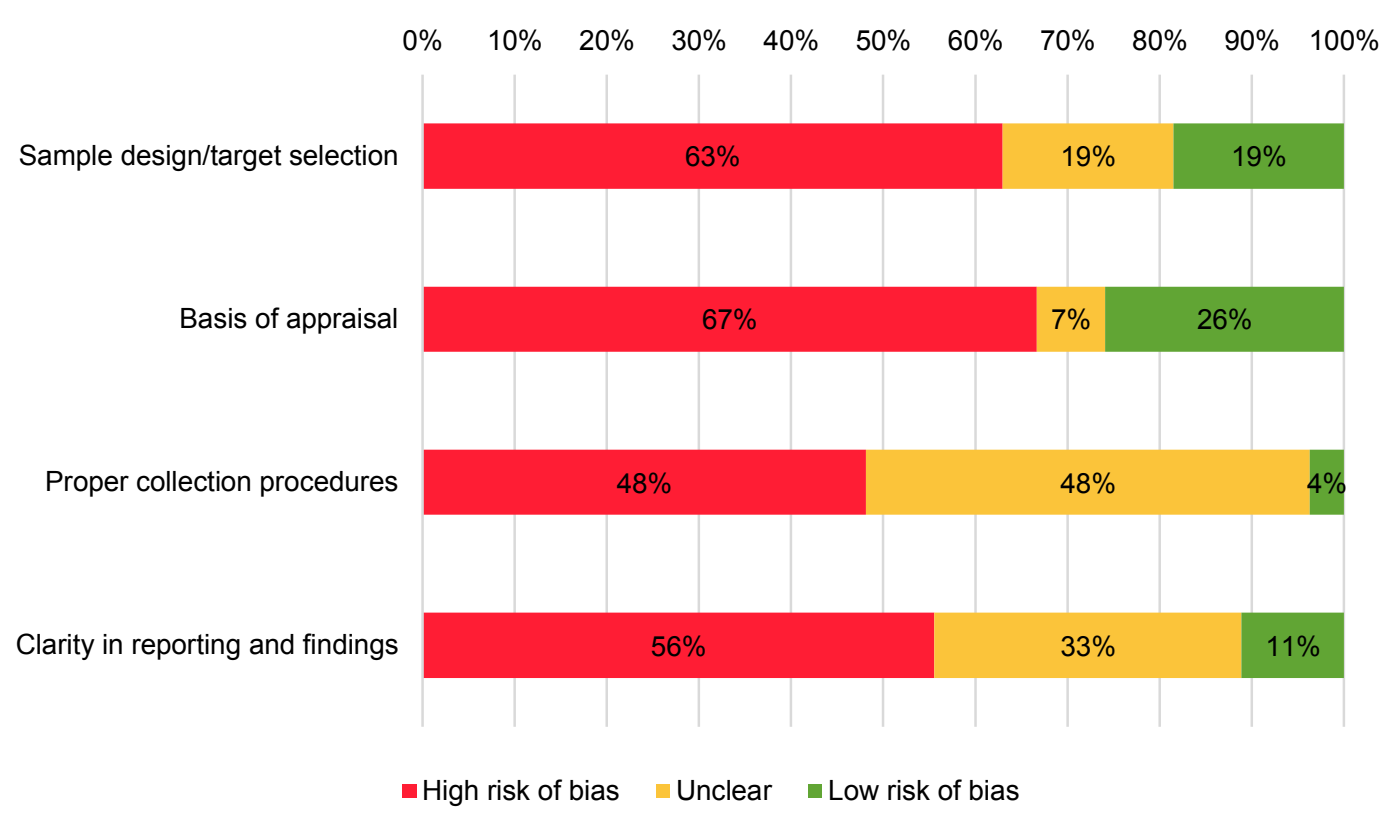

Figure D.7: Summary risk of bias for qualitative and field commentary studies

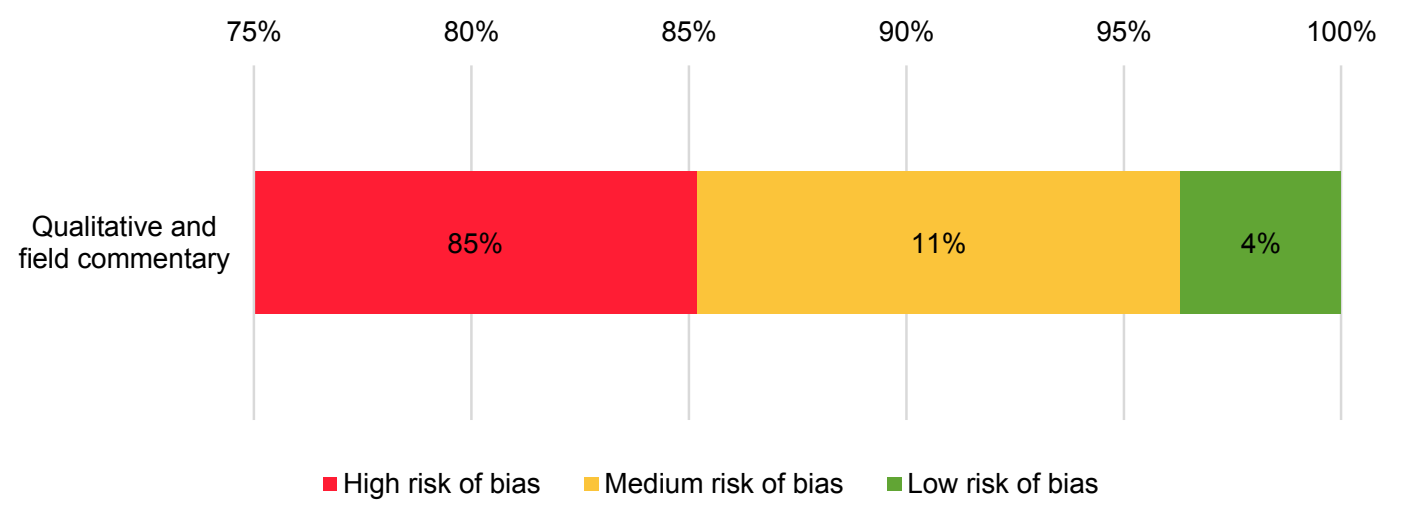


Figure D.8: Qualitative and field commentary risk of bias by category

\begin{tabular}{|c|c|c|c|c|c|}
\hline & $\begin{array}{c}\text { Sample } \\
\text { design/target } \\
\text { selection }\end{array}$ & $\begin{array}{c}\text { Basis of } \\
\text { appraisal }\end{array}$ & $\begin{array}{c}\text { Proper } \\
\text { collection } \\
\text { procedures }\end{array}$ & $\begin{array}{l}\text { Clarity in } \\
\text { reporting and } \\
\text { findings }\end{array}$ & Overall \\
\hline Williams, Gaines et al. 2015 & Low & Low & Low & Unclear & Low \\
\hline Wall and Chéry, 2011 & Low & Low & Unclear & Unclear & Medium \\
\hline Steele, Clarke et al., 2008 & High & High & High & High & High \\
\hline Simpson, Bazezew Legesse et al., 2009 & Unclear & Unclear & High & High & High \\
\hline Rowe, 1998 & High & Low & High & High & High \\
\hline Garandeau, Trevett et al., 2006 & High & Low & High & Unclear & High \\
\hline DeGabriele and Musa, 2009 & High & High & Unclear & Low & High \\
\hline Walden, Lamond et al., 2005 & High & High & High & High & High \\
\hline Grayel, 2011 & High & High & High & High & High \\
\hline Waterkeyn, Okot et al., 2005 & High & High & High & High & High \\
\hline WHO, no date - South Africa & High & High & Unclear & Unclear & High \\
\hline WHO, no date - Zimbabwe & High & High & Unclear & Unclear & High \\
\hline Pennacchia, Poidatz et al., 2011 & High & High & Unclear & High & High \\
\hline Dunoyer and Sudre, 2012 & High & High & High & Unclear & High \\
\hline Condor and Rana, 2011 & High & High & Unclear & High & High \\
\hline Rees-Gildea, 2013 & Unclear & Low & High & High & High \\
\hline Neseni and Guzha, 2009 & Unclear & Unclear & Unclear & Low & High \\
\hline Matemo, 2014 & Unclear & High & Unclear & High & High \\
\hline El-Mahmid and Roussy, 2009 & High & High & High & High & High \\
\hline ACF, 2007 & High & High & High & High & High \\
\hline Guevart, Van Hecke et al., 2008 & Low & Low & Unclear & Unclear & Medium \\
\hline ACF, 2015 & High & High & Unclear & Unclear & High \\
\hline Flachenberg, 2014 & High & High & High & High & High \\
\hline
\end{tabular}



Published by Oxfam GB for Oxfam International under ISBN 978-0-85598-875-3 in February 2017.

Oxfam GB, Oxfam House, John Smith Drive, Cowley, Oxford, OX4 2JY, UK.

\section{OXFAM}

Oxfam is an international confederation of 20 organizations networked together in more than 90 countries, as part of a global movement for change, to build a future free from the injustice of poverty. Please write to any of the agencies for further information, or visit www.oxfam.org. 